\title{
Articles
}

\section{Patent Reform and Differential Impact}

\section{Matthew Sag * \& Kurt Rohde ${ }^{* *}$}

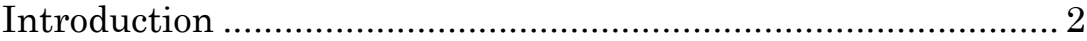

Part I. The Need for a Prioritizing Tool.................................... 8

A. The Problem with Patents ........................................... 8

B. A Differential Impact on Bad Patents ...................... 12

Part II. The Origin and Survival of Bad Patents ..................... 16

A. Patent Examination.................................................... 16

B. The Persistence of Bad Patents.................................. 22

C. Implications of the Challenger Focused Model ........... 30

D. Differential Impact and the Challenger Focused Model......................................................................... 42

E. An Assertion Focused Model .................................... 45

F. Implications of the Assertion Focused Model for Patent Reform.......................................................... 47

G. The Relevance of Economic Models to Patent

Reform.................................................................... 50

Part III. Applying the Differential Impact Test ..................... 51

A. Examination Reform................................................. 52

(C) 2007 Matthew Sag \& Kurt Rohde.

Matthew Sag is an Assistant Professor at De Paul University College of Law. The authors wish to thank Andrew Gold, David Franklin, Tim Holbrook, Tonja Jacobi, Mark Lemley, Michael Meurer, Adam Mossoff, Kali Murray, Kristen Osenga, and the participants at the Intellectual Property Scholars Conference 2006 for their insightful comments and suggestions. This article solely reflects the opinions of the authors and does not represent the views of McDonnell Boehnen Hulbert \& Berghoff LLP or its clients. Please direct any comments to msag@depaul.edu.

** $\quad$ Kurt Rohde is an Associate Attorney at McDonnell Boehnen Hulbert \& Berghoff LLP in Chicago, Illinois, where he practices as intellectual property attorney focusing on patent prosecution and patent litigation. Mr. Rohde graduated from Northwestern University School of Law and, prior to that, worked as a practicing engineer in the aerospace and industrial manufacturing fields for ten years. 


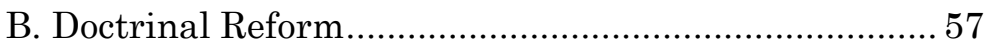

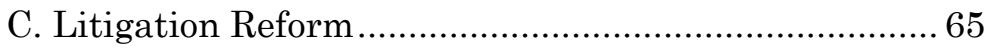

D. Assessing Patent Reform on the Basis of Differential Impact .................................................... 75

Part IV. Multistage Post-Grant Review .................................. 76

A. A Variable Presumption of Validity .......................... 77

B. Multi-stage Post-Grant Review ................................. 80

C. Claim Construction and Post-Grant Review .............. 84

D. Disputed Features of Post-Grant Review .................. 88

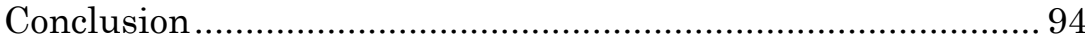

"We can't reject something just because it's stupid."

- Esther M. Kepplinger, Deputy Commissioner of the U.S. Patent \& Trademark Office. ${ }^{1}$

"Microsoft Patents Ones, Zeroes."

- THE ONION, March 25, 1998. ${ }^{2}$

\section{INTRODUCTION}

The United States patent system is facing a crisis of confidence. There is a widespread perception that changes in the standards of patentability, the increasing importance of the information economy and the sheer volume of applications before the United States Patent and Trademark Office (Patent Office) have combined to overwhelm the patent system. ${ }^{3}$

Bad patents and costly litigation lie at the heart of this crisis. Academics, business leaders and government officials have all expressed concern that too many patents are issued for "inventions" that are obvious, vague or already widely used. ${ }^{4}$ In

1. Responding to the Federal Circuit's decision in In re Lee, 277 F.3d 1338, 1345 (Fed. Cir. 2002). See David Streitfeld, Note: This Headline is Patented, L.A. Times, Feb. 7, 2003, at 1.

2. Microsoft Patents Ones, Zeroes, THE OnION (Mar. 25, 1998) at 33-11, available at http://www.theonion.com/content/node/29130. The Onion is a satirical newspaper.

3. Staff of H. Comm. on the Judiciary, 109Th Cong., Patent Quality IMPROVEMENT (Comm. Print 2005), available at http://commdocs.house.gov/committees/judiciary/hju20709.000/hju20709_1.htm.

4. See, e.g., Editorial, Patent Sanity is Pending, L.A. TIMES, Dec. 4, 2005, at M.4; see also FEDERAL Trade Commission, To Promote InNOVATION: The Proper Balance of Competition AND PATENT LAW AND Policy (2003), 
addition to patents that should never have been issued, attempts by patent holders to extend their rights to devices and services that bear little or no relationship to their initial patent application are equally problematic. These overreaching claims have been made possible because the scope of issued patents is hopelessly unclear. ${ }^{5}$

Technology heavyweights including Intel, Microsoft, and Oracle argue that although the patent system is the foundation for the United States' global leadership position in technological development, there is a pressing need to restore the balance between the rights of patent holders and the broader social good of encouraging innovation. These companies fear that, rather than encouraging the "progress of science and the useful arts" as required by the United States Constitution, ${ }^{6}$ declining patent quality and overly broad patent rights are reducing incentives to invest in manufacturing, research and development. ${ }^{7}$ Even obvious beneficiaries of the patent system, such as IBM, which receives more U.S. Patents than any other company, strongly support calls for patent reform. ${ }^{8}$

Calls for reform from the technology sector have begun to resonate in the media and in the Supreme Court; yet efforts in Congress to implement patent reform legislation have repeatedly failed. ${ }^{9}$ Editorials from several major papers decry that "there's something rotten in the U.S. patent system;"10 "the U.S. patent system is profoundly flawed;" 11 and that "the nation's patent system is a mess." 12 The Supreme Court has recently heard cases

available at http://www.ftc.gov/os/2003/10/innovationrpt.pdf [hereinafter FTC REPORT].

5. See infra Part I.

6. The United States Constitution provides Congress with the power "To promote the Progress of Science and useful Arts, by securing for limited Times to Authors and Inventors the exclusive Right to their respective Writings and Discoveries." U.S. CONST. art. I, § 8, cl. 8.

7. See Patti Waldmeir, Get it Now from Ebay, Hostage to the Patent Trolls, Fin. TIMES, Mar. 16, 2006, at 15.

8. IBM, PATENT REFORM: IMPROVE QUALiTy, REDUCE LiTIGATION, AND ENCOURAGE

INNOVATION,

http://www.ibm.com/ibm/governmentalprograms/ibmpatentreform.pdf; see also, Brendon Chase, IBM Calls for Patent Reform, ZDNET AusTRALIA, Apr. 11, 2005, http://www.zdnet.com.au/news/0,39023165,39187609,00.htm.

9. See infra notes 19-21 and accompanying text.

10. The Problem with Patents, The WALL ST. J., Mar. 29, 2006 at A18.

11. Editorial, Patent Sanity is Pending, supra note 4.

12. Editorial, U.S. Patent System Has Run Aground, The Boston Herald, July 24, 2005, at 26; see also Monopolies of the Mind, THE ECONOMIST, Nov. 13, 2004 , at 14 . 
on the scope of patent injunctions, ${ }^{13}$ the limits of patentable subject matter, 14 the status of patent rights in antitrust proceedings, 15 the application of the experimental use doctrine in clinical trials ${ }^{16}$ and future of the Federal Circuit's "teachingsuggestion-motivation" test in relation to obviousness. ${ }^{17}$

In 2005, Congressional Representatives Lamar Smith and Howard Berman proposed a bi-partisan reform bill that would have dramatically changed the patent landscape. ${ }^{18}$ However, that bill was shelved at the end of 2005 due to time restrictions and the failure of the House Judiciary Committee to negotiate a consensus between technology interests, the pharmaceutical industry, and independent inventors. ${ }^{19}$ Undeterred, Representative Smith yet again proposed significant changes to the United States patent system, this time under the rubric of the Patents Depend on Quality Act of 2006, ("the House Bill"). ${ }^{20}$ On August 3, 2006, Senators Orrin Hatch and Patrick Leahy introduced an alternative compromise bill intended to bridge the impasse between various stakeholders ("the Senate Reform Bill"). ${ }^{21}$ Regrettably, both these pieces of legislation were set aside in late 2006 because of looming mid-term elections in November of that year.

There is no shortage of ideas as to how to reform the United States patent system - there may in fact be too many such

13. See, e.g., eBay Inc. v. MercExchange, L.L.C., 126 S. Ct. 1837 (2006).

14. Lab. Corp. of Am. Holdings v. Metabolite Labs., Inc., 126 S. Ct. 2921 (2006) (dismissing writ of certiorari as improvidently granted).

15. Ill. Tool Works Inc. v. Indep. Ink, Inc., 126 S. Ct. 1281 (2006).

16. Merck KGAA v. Integra Lifesciences I, Ltd., 545 U.S. 193 (2005).

17. KSR Int'l Co. v. Teleflex, Inc., 126 S. Ct. 2965 (2006) (granting writ of certiorari). The Supreme Court heard oral arguments in this case on Tuesday, November 28, 2006.

18. Patent Reform Act of 2005, H.R. 2795, 109th Cong. (2005) (introduced June 8, 2005, by Representative Lamar Smith, Chairman of the House Subcommittee on Courts, the Internet, and Intellectual Property).

19. See, e.g., Patent Reform 2005 -- It is Over, http://patentlaw.typepad.com/patent/2005/12/patent_reform_2.html (Dec. 8, 2005).

20. The bill was introduced on April 5, 2006. See Representative Howard Berman, Statement on the Patents Depend on Quality Act of 2006 (Apr. 5, 2006), available at http://www.house.gov/list/speech/ca28_berman/Patent_Quality.html.

21. See Press Release, Senator Orrin G. Hatch, Hatch Introduces Patent Reform Legislation (Aug. 7, 2006), available at http://hatch.senate.gov/index.cfm?FuseAction=PressReleases.Detail\&PressReleas e_id=1642; Patent Reform Act of 2006, S.3818, 109 ${ }^{\text {th }}$ Cong. (2006). 
proposals. ${ }^{22}$ The Federal Trade Commission (FTC) ${ }^{23}$ and the National Academy of Sciences (NAS) ${ }^{24}$ have both issued comprehensive reports on the subject in the last few years; days, if not weeks, of congressional hearings have been devoted to patent reform; and there is an extensive body of law review literature proposing reforms to the way patents are examined, changes to substantive patent law doctrines, and structural reform of patent litigation. ${ }^{25}$ However, as the failure of the Patent Reform Act of 2005 and the House and Senate Patent Reform Bills of 2006 demonstrate, there may, in fact, be too many reform proposals currently on the table. Missing from the current patent reform debate is a rational methodology by which Congress can prioritize its reform agenda. This article fills that

22. An unrestricted search of the LexisNexis U.S. Law Review Database for the term "patent" within five words of the term "reform" yields over 700 hits, restricting that search to the last 5 years yields over 400 hits. Significant literature in this area includes Rebecca S. Eisenberg, Obvious to Whom? Evaluating Inventions from the Perspective of PHOSITA, 19 BERKELEY TECH. L.J. 885 (2004); Joseph Farrell \& Robert P. Merges, Incentives to Challenge and Defend Patents: Why Litigation Won't Reliably Fix Patent Office Errors and Why Administrative Patent Review Might Help, 19 BERKELEY TECH. L.J. (2004); Jay P. Kesan, Carrots and Sticks to Create a Better Patent System, 17 BERKELEY TECH. L.J. 763 (2002); Jay P. Kesan and Andres A. Gallo, Why 'Bad' Patents Survive in the Market and How Should We Change?-The Private and Social Costs of Patents, 55 EMORY L.J. 61 (2006); F. Scott Kieff, The Case for Registering Patents and the Law and Economics of Present Patent-Obtaining Rules, 45 B.C. L. REV. 55 (2003); Mark A. Lemley, Rational Ignorance at the Patent Office, 95 Nw. U. L. REV. 1495 (2001); Robert P. Merges, As Many as Six Impossible Patents Before Breakfast: Property Rights for Business Concepts and Patent System Reform, 14 BERKELEY TECH. L.J. 577 (1999); Joseph Scott Miller, Building a Better Bounty: Litigation-Stage Rewards for Defeating Patents, 19 BERKELEY TECH. L.J. 667 (2004); Arti K. Rai, Allocating Power over Fact-Finding in the Patent System, 19 BERKELEY TECH. L.J. 907 (2004); Arti K. Rai, Engaging Facts and Policy: A Multi-Institutional Approach to Patent System Reform, 103 COLUM. L. REV. 1035 (2003); John R. Thomas, The Responsibility of the Rulemaker: Comparative Approaches to Patent Administration Reform, 17 BERKELEY TECH. L.J. 727 (2002); John R. Thomas, Collusion and Collective Action in the Patent System: A Proposal for Patent Bounties, 2001 U. ILL. L. REV. 305 (2001).

23. FTC REPORT, supra note 4 (providing an analysis of the interaction of competition and patent law offering ten recommendations for patent system reform).

24. NAT'L RESEARCh COUNCIL OF THE NAT'L ACADS., A PATENT System FOR THE 21ST CENTURY (Stephen A. Merrill, et al. eds. 2004), available at http://www.nap.edu/html/patentsystem/0309089107.pdf [hereinafter NAS REPORT]. (The National Academy of Sciences report on the U.S. patent system was released shortly after the FTC Report and contained seven key recommendations for reforming the patent system that closely parallel the FTC's suggestions).

25. See infra Part I.B. 
gap by proposing a test of differential impact for patent reform. ${ }^{26}$ For a reform proposal to have a differential impact on bad patents it must discourage the acquisition and/or assertion of bad patents without affecting the value of good patents.

The differential impact approach elucidated in this article has three distinct advantages over other proffered efforts to rewrite the patent system from the ground up. First, the differential impact approach provides a mechanism by which to evaluate competing claims for legislative resources. This is significant because without such an approach there is no way to decide how a reform in relation to patent examination should be compared to a reform to the structure of patent litigation. Second, the differential impact approach is an appropriate response to the empirical uncertainty surrounding optimal patent scope. Many of the current reform proposals proceed from the assumption that patents are either too easy to get, or too easy to enforce - an assumption which is, as yet, unproven. In contrast, as discussed in detail in Part II of this article, we do know with some certainty that bad patents are too easy to get and too easy to enforce. Third, differential impact is consistent with the need to take the legitimate expectations of current stakeholders into account.

If the patent system is to continue to fulfill its constitutional function of promoting rather than hindering innovation, we must tailor patent reform to address the problems related to bad patents without unduly prejudicing the interests of the holders of good patents. Consequently, rather than attempt to strengthen or weaken the exclusive rights of patent holders across the board, we believe that highest priority should be given to those reforms that have a differential impact: i.e. those reforms that are likely to raise the cost of obtaining or enforcing a bad patent more than they raise the cost of obtaining or enforcing a good patent. The failure of the legislative reform efforts thus far underscores the importance of prioritizing the most important elements of patent reform - those with differential impact.

The structure of the article is as follows. Part I provides an introduction to the problems created by bad patents and introduces the differential impact test for evaluating patent reform proposals. Part II examines the origin of bad patents and applies two different economic models to explain their persistence. The first model focuses on a potential infringer's

26. See infra Part I.B. 
incentives to challenge a bad patent; the second model focuses on a patent holder's incentive to assert a patent. We explain bad patents as an emergent phenomenon: they are the product of the apparently low quality of patent examination ${ }^{27}$ and the complex, uncertain, expensive and time-consuming nature of patent litigation. ${ }^{28}$

Part III then assesses the major patent reform proposals currently under consideration against the test of differential impact in light of the economic models developed in the previous section. From this analysis, we conclude that Congress' highest priority for patent reform should be the adoption of a system of post-grant review of patent validity. Post-grant review will have a differential impact by significantly lowering the cost of challenging the bad patents. ${ }^{29}$ The differential impact test supports the adoption of post-grant review which will provide a low cost method of challenging patents which appear highly likely to be invalid or hyper-asserted. A well designed system of postgrant review will not impose a significant burden on good patent holders because those few good patents that are occasionally subject to review are unlikely to be found invalid. Furthermore, post-grant review will actually benefit good patents by reducing uncertainty and information asymmetries relating to patent quality.

Part IV demonstrates that in addition to supporting the idea of post-grant review in general, the differential impact test may also be applied to build a better model for post-grant review. Looking at post-grant review through the lens of differential impact leads us to propose a system that is very different from those embodied in current legislative and other proposals. In short, we propose: (i) adopting a variable presumption of validity depending on the level of review that a patent has been subject to; (ii) implementing a multiple stage system of post-grant review with two distinct stages in order to balance the goal of greater scrutiny for bad patents with the need to minimize potential harassment of good patents; and (iii) bringing questions of claim construction into post-grant review such that both sides of the

27. See infra Part II.A.

28. See infra Part II.B.

29. See infra Part II.C. See generally Stuart J.H. Graham and Dietmar Harhoff, Can Post Grant Reviews Improve Patent System Design? A Twin Study of US and European Patents (Governance and the Efficiency of Economic Systems, Discussion Paper No. 38, 2006), available at http://www.gesy.unimannheim.de/dipa/38.pdf. 
bad patent phenomenon can be addressed. These proposals are all designed to ensure that post-grant review provides a low cost way to challenge bad patents, but does not undermine the value of good patents.

\section{PART I. THE NEED FOR A PRIORITIZING TOOL}

\section{A. The Problem With Patents}

Historically patents were intended to reward research and innovation; however, in its modern incarnation, the U.S. patent system creates numerous perverse effects that undermine that central mission. Some of the more trivial illustrations of the perversity of the modern patent system include patents such as the Tarzan Swing Method, 30 the Beerbrella, ${ }^{31}$ a Method for Exercising Your Cat (with a laser pointer), ${ }^{32}$ the Hair Comb-Over Patent, ${ }^{33}$ and the Peanut Butter \& Jelly Sandwich patent. ${ }^{34}$ These patents are silly, but they are typically of little consequence except to prompt the question, "what else has the Patent Office been doing?" The real damage to the effectiveness of the patent system is done by "bad patents" - patents which either should never have been granted, or are asserted well beyond their legitimate scope. ${ }^{35}$

The danger of bad patents is that they undermine the incentive function of the patent system. A patent monopoly imposes costs on third parties who must either license the patent,

30. U.S. Patent No. 6,368,227 Abstract (filed Nov. 17, 2000) ("A method of swing [ing] on a swing is disclosed, in which a user positioned on a standard swing suspended by two chains from a substantially horizontal tree branch induces side to side motion by pulling alternately on one chain and then the other.").

31. U.S. Patent No. 6,637,447 Abstract (filed Oct. 19, 2001) (“[a] small umbrella ... which may be removably attached to a beverage container in order to shade the beverage container from the direct rays of the sun.").

32. U.S. Patent No. 5,443,036 Abstract (filed Nov. 2, 1993) ("A method for inducing cats to exercise consists of directing a beam of invisible light produced by a hand-held laser apparatus onto the floor . . . then moving the laser so as to cause the bright pattern of light to move in an irregular way fascinating to cats.").

33. U.S. Patent No. 6,257,248 (filed Dec. 10, 1999) (patent for cutting or styling hair using scissors or combs in both hands).

34. U.S. Patent No. 6,004,596 (filed Dec. 8, 1997) ("a sealed crustless sandwich"). For many other examples see freepatentsonline, http://www.freepatentsonline.com/crazy.html (last visited Jan. 20, 2007).

35. The term "bad patents" is defined more exactly in Part I.B, infra. 
challenge the patent in court, or expend resources to avoid infringement by designing around the patent. Where patents are properly granted and properly asserted, the monopoly cost of the patent holder's rights and her incentive to invest in innovation are generally two sides of the same coin. However, the system creates perverse incentives if all the advantages of a patent monopoly are in fact available to those who merely industriously create or collect bad patents, as opposed to those who invest (directly or indirectly) in innovation. ${ }^{36}$ If a baseball player could get a home run from hitting a foul ball, there would not be much incentive to try to hit the ball into the field.

Bad patents should not be confused with so-called patent trolls. ${ }^{37}$ Popular and academic discussion of the assertion of patent rights by non-practicing entities is commonly linked to questions of patent quality, but the issues of "bad patents" and "patent trolls" are in fact severable. We are not aware of any evidence that patent trolls are more likely to have or assert bad patents than practicing entities. The key argument against patent trolls is not that their assertions are necessarily invalid, but rather that they are in a position to negotiate licensing fees that are grossly out of alignment with their contribution to the alleged infringer's product or service. ${ }^{38}$ The reforms addressed in this article do not begin to address that problem, except in so far as a particular troll is relying on a bad patent. ${ }^{39}$

The meritless assertion of patent rights diverts scarce research and development funding from engineering to

36. As the NAS notes in its 2004 report, "patents on trivial innovations may confer market power or allow firms to use legal resources aggressively as a competitive weapon without consumer benefit." See NAS REPORT, supra note 24, at 95 .

37. The term "patent troll" was initially coined a lawyer at Intel Corporation to describe entities "that try to make a lot of money off a patent that they are not practicing and have no intention of practicing and in most cases never practiced." Alan Murray, War on 'Patent Trolls' May Be Wrong Battle, Wall ST. J., Mar. 22, 2006, at A2. The term is now broadly understood as a derogatory shorthand for any non-practicing entity that asserts patent rights. See Wikipedia, Patent Troll, http://en.wikipedia.org/wiki/Patent_troll\#Definition_and_etymology (last visited Jan. 20, 2007).

38. See Mark A. Lemley \& Carl Shapiro, Patent Holdup and Royalty Stacking (2006), (working paper on file with authors.).

39. In spite of its widespread use, the exact definition of the term patent troll is disputed. See, e.g., Transcript of Oral Argument at 7, lines 4-6, eBay, $126 \mathrm{~S}$. Ct. 1837 (No. 05-130) ("Well, is the troll the scary thing under the bridge, or is it a fishing technique?"). Note that $\S 5$ of the Senate Bill attempts to codify an "apportionment" rule for the calculation of damages for patent infringement that would reduce the leverage of so-called patent trolls. S. 3818, 109th Cong. $§ 5$ (2006). 
lawyering; it also diverts patent licensing revenue from the holders of good patents. A proliferation of unmeritorious allegations of patent infringement and subsequent litigation is clearly bad for defendants, but it is also bad for those companies that have invested in innovation and rely on the patent system to protect that investment. The aggressive tactics of the bad patent holders increases the transaction costs for good patent holders when they wish to signal that their claims of infringement must be taken seriously.

The availability of robust patent protection acts as a significant stimulus to investment in research, development, and innovation. However, when aggressive patent holders can extract substantial license fees simply through leveraging the overwhelming costs and delays involved in challenging a patent, whether good or bad, the incentives to get a good patent are reduced and the overall burden of the patent system on society is increased.

Consider the hypothetical example of Carla, a small Internet retailer. Just before the critical holiday retail season, Carla receives a letter from a patent licensing firm. The letter states that the firm is willing to negotiate a license, based on the firm's asserted patent rights, concerning a particular aspect of Internetbased shopping cart checkout technology that Carla uses on her website. The firm offers the license for an annual fee of $\$ 50,000$.

Carla is suspicious of the validity of the patent because the claimed invention seems too broad and abstract. She is also suspicious because the idea of this electronic shopping cart technology has been in common use for so long that she does not equate it with patented technology. Armed with these suspicions, Carla asks Jane, a friendly patent lawyer, for some help. After reviewing the letter and the patent, Jane offers several pieces of information and advice: (1) the patent should probably never have been issued for a number of reasons, most obviously because it was "anticipated" by an earlier invention that the Patent Office examiner was not aware of; 40 (2) for $\$ 30,000$, Carla can get an opinion letter that says the patent is invalid and that even if it was valid, she does not infringe it; 41 (3) without such a letter,

40. 35 U.S.C. $§ 102$ (2000) (novelty provisions).

41. AM. Intellectual Prop. LAW Assoc., RePort of the ECONOMiC SURVEY 102 (2005) [hereinafter, AIPLA ECON. SURVEY]. Although the average cost of a patent opinion from a mid-sized firm is $\$ 23,997$, prices as high as $\$ 40,000$ are not uncommon in areas such as New York City. Id. 
Carla may be liable for treble damages and attorney's fees for the entire period since she received the patent holder's letter if she is later found to infringe the patent; 42 (4) Carla probably cannot go to court to have the patent declared invalid because she lacks standing for declaratory judgment; 43 (5) even if Carla could persuade a court to hear her case, it would probably cost her around $\$ 650,000$ to invalidate the patent (give or take a few hundred thousand dollars); 44 (6) given that the patent is likely flawed, Carla could submit it to the Patent Office for an administrative process known as reexamination based on the existence of prior art - but if she does, she either won't be able to participate meaningfully in that reexamination process, ${ }^{45}$ or worse still, if she loses her reexamination in the Patent Office, she won't be able to make the same arguments again in any later court proceeding. ${ }^{46}$ In the end, Jane cheerfully suggests that Carla should consider paying the $\$ 50,000$, regardless of the likely invalidity of the patent.

This is the real perversity of the current patent system: rational actors will pay licensing fees for patents they strongly suspect are either invalid, or simply do not apply to them, because each of the alternatives is worse.

42. See Knorr-Bremse Systeme Fuer Nutzfahrzeuge GmbH v. Dana Corp., 383 F.3d 1337, 1342 (Fed. Cir. 2004). The remedy for willful infringement is based on 35 U.S.C. $\$ 284$ (2000) ("the court may increase the damages up to three times the amount found or assessed") and 35 U.S.C. $§ 285$ (2000) ("the court in exceptional cases may award reasonable attorney fees to the prevailing party").

43. Vermeer Mfg. Co. v. Deere \& Co., 379 F. Supp. 2d 645 (D. Del. 2005) (patent holder did not create a reasonable apprehension of suit through a letter stating that the patent holder would enforce its patent rights and that the opposing party appeared to infringe on the patent). However, the recent Supreme Court decision in MedImmune, Inc. v. Genentech, Inc may signal the immergence of a more flexible doctrine relating to requirements in patent cases. 127 S. Ct. 764 (2007) (holding that the requirements of a case or controversy are met where payment of a claim is demanded as of right and where payment is made, but where the involuntary or coercive nature of the exaction preserves the right to recover the sums paid or to challenge the legality of the claim.)

44. AIPLA ECON. SURVEY, supra note 41, at 108.

45. The Patent Act provides for both ex parte reexaminations under 35 U.S.C. $§ 302$ (2000) and inter partes reexamination under 35 U.S.C. $§ 311$ (2000). The Act also provides for Commissioner ordered reexaminations under 35 U.S.C. $\S 303(\mathrm{a})$ (2000). See generally UNITED STATES PATENT AND TRADEMARK OFFICE, REPORT TO CONGRESS ON INTER PARTES REEXAMINATION, http://www.uspto.gov/web/offices/dcom/olia/reports/reexam_report.htm (last visited Jan. 20, 2007).

46. The Patent Act provides that any issue raised by a challenger during reexamination cannot be revisited in a later trial involving that challenger. See 35 U.S.C. $§ 317$ (2000). See also Farrell \& Merges, supra note 22, at 967. 
[Vol. 8:1

\section{B. A Differential ImpaCt on BAD PATENTS}

Congress faces a dizzying array of options when it comes to overhauling the patent system, but what is lacking from the patent reform debate so far is a framework for prioritizing these reforms. This article addresses that need by proposing that Congress should apply the differential impact test to determine which reforms are most pressing. We argue that the highest priority for patent reform should be reserved for those measures that will have a differential impact on bad patents. This raises two questions: first, what is it about a patent that makes it bad; and second, what is differential impact?

\section{Defining Bad Patents}

For all the discussion of falling patent quality and opportunistic litigation, there appears to be no agreed-upon definition of what makes a patent "bad." The term is often used loosely to denote patents that should not have been issued. ${ }^{47}$ Patents can fail to meet the standards of patentability despite being issued by the Patent Office. ${ }^{48}$ Currently, roughly half of all litigated patent claims are found invalid by the courts for reasons such as anticipation or obviousness. ${ }^{49}$ Are all of these patents "bad"? We doubt it. Defining bad patents solely with reference to standards of patentability is problematic. For example, it is not uncommon for a patent to be found to be invalid on the basis of prior art that the applicant could not reasonably be expected to have known about. 50 Similarly, the uncertain nature of claim

47. See, e.g., Edward Hsieh, Note, Mandatory Joinder: An Indirect Method for Improving Patent Quality, 77 S. CAL. L. REV. 683 (2004) (defining bad patents as "patents that do not meet the statutory requirements of novelty and nonobviousness."); see also Katharine M. Zandy, Too Much, Too Little, or Just Right? A Goldilocks Approach to Patent Reexamination Reform, 61 N.Y.U. ANN. SURV. AM. L. 865, 905 (defining bad patents as "patents that are likely to be invalidated if subjected to litigation or an administrative challenge.) Jay Kesan offers a more helpful definition; he uses the term as follows: "a patent is "bad" if it should not have been granted by the Patent Office after a reasonable search and review of the relevant prior art." See Kesan, supra note 22.

48. Primarily novelty, 35 U.S.C. $§ 102$, non-obviousness, 35 U.S.C. $§ 103$, and written description, enablement and best mode, 35 U.S.C. $§ 112$.

49. John R. Allison \& Mark A. Lemley, Empirical Evidence on the Validity of Litigated Patents, 26 AIPLA Q.J. 185, 205-206 (1998) (reporting that, in a sample of 300 cases, only $54 \%$ of final validity decisions found the patent valid. This analysis is at the patent level, not the claim level but the authors of this study treat cases with split rulings on claim validity as two separate patents).

50. See, e.g., In re Hall, 781 F.2d 897, 898-899 (Fed. Cir. 1986) (holding that a single copy of a doctoral thesis, properly cataloged in the collection of a German 
construction makes predicting the ultimate validity of any patent claim a speculative art at best. ${ }^{51}$ For these reasons we believe that it would be over-inclusive to define bad patents as those patents that should not have been issued given the wisdom of hindsight. Clearly, part of the definition of bad patents must encompass patents that a reasonably diligent applicant would have known failed to meet the statutory requirements of patentability. But such patents are merely the beginning of the bad patent phenomenon.

As an alternative to defining bad patents simply as invalid patents, we propose a functionalist definition of bad patents that focuses more clearly on those patents which are likely to distort the allocation of resources. The British Telecom ("BT") hyperlink patent provides a good example of a different kind of bad patent. In 2002, telecommunications giant BT attempted to assert patent rights over the creation of hyperlinks on the Internet. One of the many striking things about BT's claims was that this patent was initially filed in $1976^{52}$, well before the technology they effectively claimed to own was invented. 53 BT's U.S. Patent No. 4,873,662, eventually issued in 1989, describes a system where multiple users can access data on a central computer by using remote terminals. BT claimed that this patent read on the technology used in Internet hyperlinks. BT contacted various Internet Service Providers ("ISP") and demanded license fees, claiming that the ISP's actions facilitated the infringement of the patent by providing ISP subscribers with access to the Internet. When eventually challenged in federal court, BT's infringement claims were dismissed on summary judgment, with the judge holding that no reasonable jury could have found that the scope of the patent's claims covered Internet hyperlinks. ${ }^{54}$ While the bad

University Library qualified as anticipating prior art).

51. See Cybor Corp. v. FAS Techs., 138 F.3d 1448, 1476 (Fed. Cir. 1998) (Rader, J., dissenting) (noting that almost $40 \%$ of all district court claim constructions appealed to the Federal Circuit since Markman I were reversed); see also Phillips v. AWH Corp., 415 F.3d 1303, 1330 (Fed. Cir. 2005) (Mayer, J., dissenting) (Describing the process of claim construction as mayhem); Lava

Trading, Inc. v. Sonic Trading Mgmt., LLC, 445 F.3d 1348 (Fed. Cir. 2006) (Mayer, J., dissenting).

52. That is, the U.S. patent claimed priority from a July 20, 1976 United Kingdom filing.

53. See Kurt Kleiner, BT in Court to Enforce Hyperlink Patent, NEW SCIENTIST, February 11, 2002, available at http://www.newscientist.com/article.ns?id=dn1905; U.S. Patent No. 4,873,662 (filed Aug. 15, 1980).

54. British Telecomms. PLC v. Prodigy Commc'ns Corp., 217 F. Supp. 2d 399, 401 (S.D.N.Y. 2002). 
patent assertions by BT were eventually removed from the marketplace, they were still able to cause significant financial harm before they were formally rejected.

As the litigation over the BT Hyperlink patent illustrates, even a technically valid patent can become a bad patent if it is asserted beyond its legitimate scope. The BT Hyperlink patent may well have been properly granted; however, it was the broad assertion of rights by BT that made the hyperlink patent a bad patent. 55

In sum, the term bad patent should be used to identify not only invalid patents, but also patents that are asserted (by implication or otherwise) to cover a product or activity that no reasonable fact finder in possession of all the relevant facts could find that they covered. The reason for adopting this functionalist definition of bad patents is that we are less concerned about whether a patent turns out to be technically valid, and more concerned about whether it is used as the basis for an assertion of rights that is objectively lacking in merit. A patent that should not have been issued and a patent that was validly issued but is now the subject of hyper-assertion both result in the patent holder claiming legal rights she does not in fact possess. These are the patents that undermine the incentive rationale of the patent system.

\section{Differential Impact}

In his seminal 1958 review of the economic literature relating to the patent system, economist Fritz Machlup concluded that:

No economist, on the basis of present knowledge, could possibly state with certainty that the patent system, as it now operates, confers a net benefit or a net loss upon society. ... If we did not have a patent system, it would be irresponsible, on the basis of our present knowledge of its economic consequences, to recommend instituting one. But since we have had a patent system for a long time, it would be irresponsible, on the basis of our present knowledge, to recommend abolishing it. 56

Machlup was not suggesting that there is no evidence as to whether the patent system has costs or benefits, but rather that

55. On this theory, the patent did not become "bad" until BT argued for a claim construction that was unsupported by the actual invention.

56. Fritz Machlup, An ECONOMic Review of the Patent System, SubCOMm. ON PATENTS, TRADEMARKS, AND COPYRIGHTS OF THE SENATE COMM. ON THE JUDICIARY, Study No 15, 85th Cong, 2d Sess. at 79 (1958). 
there is substantial conflicting evidence as to the magnitudes of those costs and benefits. Scholars generally agree that we are empirically uncertain about far too many things to know whether expanding or contracting scope or availability of patent rights will be beneficial. ${ }^{57}$ The interesting question is what we should do in the face of this uncertainty. Machlup himself saw no reason why uncertainty should lead to policy paralysis. He argued that regardless of the global uncertainty in relation to the patent system, "the student of the economics . . . need not disqualify himself as a judge of proposed changes in the existing system. . . a team of well-trained economic researchers and analysts should be able to obtain enough information to reach competent conclusions on questions of patent reform." 58

One of the most pressing problems in the patent system today is not that patents in general are too easy to obtain or too easy to enforce; rather it is that bad patents are too easy to obtain and enforce. The solution to this problem is not to simply make all patents less valuable. Rather, the solution is to try and reform the system so that bad patents are more easily weeded out without undue prejudice to good patents. Ideally, any change to the current patent system must benefit companies that have invested in innovation and use valid patents to protect that investment; it certainly should not harm them. In order to achieve this, we argue that the reform proposals garnering congressional attention should be uniformly assessed against a test of differential impact. The strong form of this test is that a reform must reduce the incentives for obtaining or asserting bad patents without reducing those same incentives for good patents. The weak form of the differential impact test simply requires that a reform reduce the incentives for obtaining or asserting bad patents more than it reduces those same incentives for good patents.

The differential impact test is necessary because of the empirical uncertainty as to the optimum scope of patent rights and because of the need for a targeted legislative proposal that might have a better chance of being passed by Congress. There are many reform proposals that might make sense if we were rebuilding the patent system from the ground up, but, if we are pursuing less radical change, we must keep in mind the expectations of those individuals and corporations who have

57. See Robert P. Merges \& Richard R. Nelson, On the Complex Economics of Patent Scope, 90 CoLUM. L. REV. 839 (1990).

58. MACHLUP, supra note 56. 
already invested in the current system.

The objective of this article is to explain the need for differential impact analysis of patent reform and to evaluate the current reform proposals against that test. However, in order to make that possible, it is first necessary to understand why the Patent Office issues invalid patents and how bad patents continue to survive in the market place once they have been issued. Accordingly, the next Part explores the origin and survival of bad patents.

\section{PART II. THE ORIGIN AND SURVIVAL OF BAD PATENTS}

Congressional action on patent reform should be targeted toward implementing those reforms that are most likely to have a differential impact on bad patents, that is, those reforms that will reduce the value of bad patents without undermining the value of good patents. In order to examine which reforms are most likely to have a differential impact on bad patents it is first necessary to understand why, in spite of its best efforts, the Patent Office continues to issue invalid and ill-defined patents and how those patents are used in the marketplace. In this section we use two different economic models to explain why some patent holders see value in asserting patent rights that no reasonable judge or jury would ultimately vindicate. These models also suggest which reforms are most likely to reduce this kind of activity without damaging the legitimate interests of good patent holders.

\section{A. Patent Examination}

The phenomenon of bad patents stems from both the apparent low quality of patent examination and the complex, uncertain, expensive and time-consuming nature of patent litigation. It is important to understand the relationship between these two factors. If only an insignificant number of patents were improperly issued, it would not matter very much that patent litigation was so expensive. In this scenario, only good patents would be issued and the burden of expensive patent litigation would fall largely on infringers with a real case to answer. Similarly, if challenging invalid patents was simple, quick, and cheap, it would not matter if there were vast numbers of improperly issued patents. In this alternative scenario, alleged infringers would be able to quickly ascertain the likely merits of the patent holder's claim by attempting to invalidate the patent. Knowing that alleged infringers will routinely test the quality of patents, patent holders would have a strong incentive to only 
make defensible claims of infringement. In contrast with the foregoing scenarios, the problems with the current patent system arise in part because too many potentially bad patents issue, and in part because it is too costly for alleged infringers to challenge or test their validity. ${ }^{59}$ Accordingly, the problem of bad patents cannot be understood in one-dimensional terms; it emerges from the interaction of the features of both patent examination and patent litigation.

Bad patents emerge from the Patent Office due to a combination of limited resources and distorted incentives. Almost any patent lawyer will agree that the U.S. patent system is currently overburdened: there are too many patent applications and not enough examiners to ensure that the merits of each and every patent are properly assessed. In the 2005 fiscal year, the Patent Office received over 380,000 new patent applications and issued more than 152,000 patents. ${ }^{60}$ Each one of those issued patents spent an average of two to three years in prosecution. ${ }^{61}$ Yet during that time, the average patent was probably only examined for as little as 18 hours and at most 41.5 hours. ${ }^{62}$

The Patent Office currently has 4,200 patent examiners, but plans to hire 1,000 patent examiners a year for the next several years to increase its current staff. ${ }^{63}$ Even so, given the growth in the volume of applications over the last two decades and the likely turnover of examiners at the Patent Office, 64 the office will

59. Patents are potentially rather than categorically "bad" at the time they are issued because how they will actually be used is not predetermined.

60. These figures relate to utility, plant, and reissue patent applications; U.S. PATENT AND TRADEMARK OFFICE, USPTO PERFORMANCE AND ACCOUNTABILITY REPORT FOR FISCAL YEAR 200518 (2005), available at http://www.uspto.gov/web/offices/com/annual/2005.

61. Id. at 6 ("pendency - the amount of time a patent application is waiting before a patent is issued-now averages more than two years. In more complex art areas, such as data-processing technologies, average pendency stands at more than three years.”); see also Lemley, supra note 22 , at 1500.

62. Id. Lemley cites various estimates of the amount of time spent examining the average patent ranging from eighteen to eight hours. These estimates may be out of date. According to one examiner, the average initial decision for a digital camera patent takes about twenty-four hours, to actually finalize the claims and approve the patent issues presumably takes several additional hours. See Kevin Maney, Patent Applications So Abundant That Examiners Can't Catch Up, USA TODAY, Sept. 21, 2005, at B3. We can calculate the upper bound of examination time by dividing the number of hours worked by examiners by the number of patents issued every year. Assuming 4200 examiners each allocate 1500 hours a year to examination yields 6.3 million hours of examination. Dividing this by the 152,000 patents issued in 2005 yields 41.5 hours per patent.

63. Kevin Maney, supra note 62.

64. Patent examiners, on average, spend only three to five years with the Patent Office before leaving. This means that within a four year period, the 
likely struggle to keep pace with increasing demands for examination if no other changes are made to the system. The mismatch between patent applications and examination resources has resulted in considerable delays in the time it takes the Patent Office to issue a patent. ${ }^{65}$ The Patent Office currently faces a backlog as high as 885,000 applications, many of which have not even been assigned to an examiner. ${ }^{6}$ According to its 2005 annual report, the Patent Office estimates the average time it takes to examine and issue a patent to be about twenty-nine months, although the figure is much higher in certain fields such as software and business method patents. ${ }^{67}$ Furthermore, the Patent Office reports that unless reforms are implemented or the agency's budget is expanded, the current backlog will increase to up to five years. ${ }^{68}$

As the Patent Office struggles with the availability of examination resources, it must also face the recent extension of patentable subject matter into new fields. In the past twenty-five years, legal and technological changes have combined to radically extend the application of the patent system to new areas, including software, business methods, and genomics. 69

These new frontiers of patentability have increased the strain on the Patent Office in two ways. First, increasingly permissive

equivalent of the entire current staff of examiners at the Patent Office will have left. This points to both a continuing problem of staffing levels and also a problem with retention of experienced examiners. See Randy Barrett, Report: Patent Office Should Become Federal Corporation, NAT'L J. TECH. DAILY, Aug. 24 2005, available at http://www.govexec.com/dailyfed/0805/082405td1.htm.

65. The Patent Office allegedly told an applicant for a business method patent that its recently filed application might take as long as fourteen years to be examined. See PTO: First Office Action Expected Fall 2019, http://www.patentlyo.com/patent/2006/06/pto_first_offic.html (2006).

66. Tricia Bishop, 43.5-Month Patent Process Not Moving Fast Enough, THE BALTimore SUN, Apr. 30, 2006, at 4C. (The increase has led to the fear that some patents, despite the time frame, are being granted without proper review). Victor Godinez, Patent System Under Scrutiny BlackBerry Case Highlights Complaints, Backlog of Applications, THE DALLAS MORNING NEWS, March 26, 2006. (The agency has a backlog of nearly 600,000 patent applications, and the stack is growing).

67. Id. (It takes an average of more than three years -43.5 months, to be exact - for the government to process a software patent application.).

68. See John W. Schoen, U.S. Patent Office Swamped By Backlog, Without More Funding, Wait Time Could Top 5 Years, MSNBC, Apr. 27, 2004, http://www.msnbc.msn.com/id/4788834/ (quoting Jon W. Dudas).

69. See, e.g., U.S. Patent No. 5,193,056 (filed Mar. 11, 1991) (first business method patent, ruled patentable subject matter in State Street Bank \& Trust Co. v. Signature Financial Group, 149 F.3d 1368 (Fed. Cir. 1998)). 
rules on patentable subject matter have led to a deluge of patent applications in those fields. ${ }^{70}$ Second, new subject matter patents are more difficult for the Patent Office to examine because they cannot simply turn to previously published patents to begin the search for prior art. Furthermore, patent examiners are at a comparative disadvantage in reviewing new technology because they cannot readily access outside expertise without violating the confidentiality of the patent applicant. ${ }^{71}$ Even more remarkably, patent examiners in many art areas are prohibited from searching on Google and other Internet search engines to search for prior art references. ${ }^{72}$ In response to vigorous criticism of its treatment of new subject matter, the Patent Office instituted new policies in 2000 and 2001 designed to improve patent quality in some areas. ${ }^{73}$ However, the impact of the Patent Office's new policies has thus far been difficult to judge.

In addition, the Patent Office has been affected by "technology creep."74 Old classifications such as electrical, chemical, and mechanical inventions have been displaced by far more complex fields like semiconductors, biotechnology, and nanotechnology, all of which require far more specialized expertise.

Even taking into account its limited resources, the Patent Office has been criticized for simply being too willing to grant patents. Arguably, the Patent Office's internal culture and organization predispose examiners to granting patents too easily. Factors that might contribute to a culture of permissive patent issuance include: (1) patent examiners face no penalties for issuing ultimately bad patents; ${ }^{75}$ (2) patent examiners are only

70. Jennifer A. Albert \& Emerson V. Briggs, III, Strategies of Tech Business Include Utility Patents, NAT'L L.J., Jan. 29, 2001, at B23 (reporting that "the PTO has been inundated with patent applications during the past two years and can barely keep up. It is generally understood that this increase in filings results from an influx of computer, software, and Internet-based applications in the wake of the Federal Circuit's holding in State Street.").

71. See Beth Novak, Peer to Patent: Collective Intelligence and Intellectual Property Reform, (working paper on file with the authors 2006).

72. Id.

73. See NAS REPORT, supra note 24 , at $55-56$.

74. See Schoen, supra note 68.

75. John R. Thomas, The Responsibility of the Rulemaker: Comparative Approaches to Patent Administration Reform, 17 BERKELEY TECH. L.J. 727, 733 (2001) ("Courts do not fine the USPTO upon invalidating a patent; the examiners who allowed the case are not disciplined for their oversight; nor must the USPTO award damages to affected members of the public to compensate for an improvidently granted patent. The costs of failing to acquire information are simply shifted to other actors - in particular, the federal courts, the patentee's 
rewarded for initial response to, and final determinations of, patent applications; ${ }^{76}$ and (3) continuation, continuation-in-part, and divisional applications can be used to wear down an examiner until at least some claims issue. ${ }^{77}$

The imperfect nature of patent examination is widely acknowledged. Even the Patent Office acknowledges that its error rate is around $4 \%,{ }^{78}$ although many scholars believe that number to be much, much higher. ${ }^{79}$

The FTC reports that the Patent Office's approval rate might be as high as $98 \% .80$ This is compared with a $67 \%$ approval rate in Europe and 64\% in Japan. ${ }^{81}$ The Patent Office argues that the true figure is more like a $75 \%$ approval rate or even a $60 \%$ rate. ${ }^{82}$ However, other studies that account for the effect of continuations, continuations-in-part, and divisional applications estimate the Patent Office's approval rate to be much higher. ${ }^{83}$ Whatever the reasons for the Patent Office's high rate of allowance might be, the fact that persistent applicants are almost always successful does not indicate a high threshold of quality

competitors, and, ultimately, consumers.")

76. John R. Allison et al., Valuable Patents, 92 GEO. L.J. 435, 463 (2004).

77. Id. at 456-57.

78. U.S. PATENT AND TRADEMARK OFFICE, PERFORMANCE AND ACCOUNTABILITY REPORT FOR FISCAL YEAR 200218 (2005), available at http://www.uspto.gov/web/offices/com/annual/2002/1-58.pdf (showing an official "error rate," based on internal quality assurance measures, of $4.2 \%$. An error is defined as at least one claim within the randomly selected allowed application under quality review that would be held invalid in a court of law, if the application were to issue as a patent without the required correction. Some examples of errors include the issuance of a claim having anticipatory prior art under 35 U.S.C. $\S 102$, or relevant prior art under 35 U.S.C. $\S 103$ that would render the allowed claim obvious. Other errors include lack of compliance of the claim to the other statutory requirements (e.g., 35 U.S.C. $§ 101,35$ U.S.C. $§ 112$ ) and judicially created doctrines. The error rate is the ratio of patents issued with errors to the total number of patents issued).

79. Allison \& Lemley, supra note 49 , at 205-206 (only 54\% of the patents were found valid in a population of 300 final validity decisions). While this is may be in line with standard assumptions about the selection of disputes for litigation, the difference with patents is that they have previously been subject to a review process before entering the pool for selection.

80. See FTC REPORT, supra note 4, at 217.

81. Id.

82. Id. (75\% approval rate); USPTO Director Jon Dudas, Address at 2005 AIPLA Meeting (Oct. 28, 2005).

83. C. Quillen and O. Webster, Continuing Patent Applications and Performance of the U.S. Patent Office, 11 FED. CIR. B.J. 1, 5 (2001) (finding that the Grant Rate for the PTO in fiscal years 1993-1998, corrected for continuing applications, ranges from $80 \%$ to $97 \%$ ). 
control.

The important policy question that flows from the imperfect nature of patent examination is whether it is worth spending money to make patent examination any better. Patent lawyers and a number of academics have called for better funding for the Patent Office to improve patent examination. ${ }^{84}$ In contrast, somewhat like Dr. Strangelove, 85 a few commentators have suggested giving up worrying about the issuance of invalid and uncertain patents and learning to love a system of quick-anddirty examination at the Patent Office - the theory being that poor quality patents will either be ignored by the market or dealt with through litigation. ${ }^{86}$ As Mark Lemley explains:

[S]ociety ought to resign itself to the fact that bad patents will issue, and attempt to deal with the problem ex post, if the patent is asserted in litigation. This result is admittedly counterintuitive. It depends crucially on the fact that very few patents are ever the subject of litigation, or even licensing. Because of this, money spent improving the [Patent Office] examination procedures will largely be wasted on examining the ninety-five percent of patents that will either never be used, or will be used in circumstances that don't crucially rely on the determination of validity. 87

Although the "rational ignorance" theory of patent examination is attractive, its advantages may be overstated. There are a number of reasons to suspect that bad patents are not effectively dealt with by market and judicial forces, as explained in more detail in the next section.

\section{B. The PeRsistence OF BAD PATENTS}

There would be no need to worry about improving patent

84. Legislation has even been proposed to this end. See United States Patent and Trademark Fee Modernization Act of 2005, H.R.2791, 109th Cong. (2005).

85. DR. StRangelove OR: How I LEARNEd to STOP WORRYING AND LOVE THE BOMB (Hawk Films Ltd. 1964).

86. Lemley, supra note 22, at 1497; see also Allison, supra note 76; Kieff, supra note 22 (arguing that patent applications should be registered, not examined).

87. Lemley, supra note 22, at 1510-11; see also, Farrell \& Merges, supra note 22 , at 946 ("It would be a disgrace for a system to enforce a lot of improper patents. This need not mean that it is bad if the USPTO issues a lot of invalid patents. Rather, the entire system of application, examination, issuance, negotiation, licensing, challenge, and enforcement should be evaluated as a whole.”). Lemley clearly recognizes that some examination related reforms are worth pursuing, id. at 1523-25, but his main contention is that the primary reform goal should be "to strengthen the validity inquiry made by the trial courts." Id. at 1532. Critical responses to Lemley's "rational ignorance" theory include Shubha Ghosh \& Jay Kesan, What Do Patents Purchase? In Search of Optimal Ignorance in the Patent Office, 40 Hous. L. REV. 1219 (2004). 
examination if potential infringers were able to instantly recognize bad patents when they saw them and if patent holders viewed attempting to extract revenue based on such patents as a futile exercise. However, in reality invalid and hyper-asserted patents are capable of generating significant revenues and thus have a distorting effect on the allocation of resources in the economy. Indeed, as this section explains, the delay, uncertainty, and expense of patent litigation mean that alleged infringers have weak incentives to challenge bad patents and also that patent holders have strong incentives to over-claim their rights. Understanding these incentives is central to determining which proposed reforms are likely to have a differential impact on bad patents.

\section{Weak Incentives to Challenge}

Faced with the threat of litigation from the holder of a questionable patent, an alleged infringer must choose whether to pay the license fees the patent holder demands, challenge the validity or application of the patent, or simply exit the market. ${ }^{88}$ One of the central problems with the current patent system is that there are many circumstances in which these choices will be dictated by the cost of litigation, not the validity of the patent holder's claims. In fact, the models discussed in this section demonstrate that as the cost of litigation increases, the validity of the asserted patent becomes less and less relevant to the alleged infringer's decision to challenge.

Both Farrell and Merges and Kesan and Gallo have developed formal models to determine whether litigation will adequately deal with the problem of bad patents. ${ }^{89}$ Their models are developed from the point of view of a potential defendant who is faced with the choice of licensing, ignoring, or challenging a

88. Exiting the market may mean that the alleged infringer abandons a line of business altogether or designs around the patent (thus exiting the patent market, but not the product market).

89. See, e.g., Kesan \& Gallo, supra note 22, at 85; Farrell \& Merges, supra note 22 , at 943 (arguing that litigation is an poor substitute for adequate patent examination and calling for greater funding for the Patent Office to improve patent review at the application stage); see also Mark A. Lemley \& Carl Shapiro, Probabilistic Patents, 19 J. ECON. PERSP. 76 (2005) (exploring the suboptimal incentives of private parties to challenge patents in courts and considering potential reforms); Miller, supra note 22, at 667 (proposing a regime of litigationstage bounties to encourage defendants to challenge patent validity); Edward Hsieh, Note, Mandatory Joinder: An Indirect Method for Improving Patent Quality, 77 S. CAL. L. REV. 683 (2004) (proposing a mandatory joinder solution). 
patent holder's assertion that some aspect of her business infringes on the patent holder's rights. We present here our own version of the challenger focused model which illustrates why alleged infringers will pay license fees rather than challenge bad patents in a significant number of cases.

\section{Challenger Focused Model}

The challenger focused model ("CF-model") described in this section looks at the world from the perspective of a potential infringer who has received some indication that a patent holder believes she is infringing and has demanded a royalty payment accordingly. The alleged infringer must decide whether to take a license, challenge the patent, or exit the field.

Variable Definitions:

$$
\begin{aligned}
& \Pi=\text { Profit to the potential infringer over } \\
& \text { the lifetime of the product (excluding } \\
& \text { any costs relating to the patent) } \\
& \mathrm{C}_{\mathrm{L}}=\text { Cost of license payments. } \\
& \mathrm{CP}_{\mathrm{P}}=\text { Additional penalty cost of license } \\
& \text { payments after challenging the patent } \\
& \text { and losing. } \\
& \mathrm{L}=\text { Cost of legal challenge. } \\
& \mathrm{I}=\text { Cost of gathering information related } \\
& \text { to patent validity. } \\
& \mathrm{P}=\text { Cost of any damages as a result of } \\
& \text { losing a challenge to the patent. } \\
& \mathrm{A}=\text { Probability that the alleged infringer } \\
& \text { would be able to successfully } \\
& \text { challenge the patent. }
\end{aligned}
$$

Utility Functions:

$$
\begin{array}{ll}
U_{\text {Win }} & =\Pi-L-I \\
U_{\text {Lose }} & =\Pi-L-I-C_{L}-C_{P}-P \\
U_{\text {License }} & =\Pi-C_{L}-I \\
U_{\text {Exit }} & =0 \\
U_{\text {Challenge }} & =a\left(U_{\text {Win }}\right)+(1-a)\left(U_{\text {Lose }}\right)
\end{array}
$$

When faced with the scenario above, the alleged infringer of a potentially bad patent will decide whether to challenge the 
patent, take a license, or exit the field based on which is least costly or most profitable. Generally, an alleged infringer will challenge the patent if her utility from doing so exceeds her utility from simply accepting the license demands of the patent

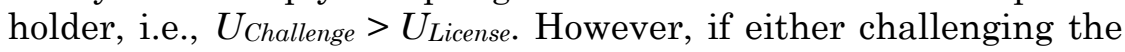
patent or accepting the license would drive the alleged infringer out of business, that is, $U_{\text {Challenge }}<0$ and $U_{\text {License }}<0$, then the alleged infringer will simply exit the field. There are a number of different ways in which patent holders can obtain value from an individual patent or from a portfolio of patents: (1) they can use patents to exclude competitors from certain markets and thus charge higher prices (the exclusive strategy), (2) they can use the threat of exclusion to extract license fees (the extractive strategy), (3) they can use the threat of retaliatory litigation to avoid paying license fees for activity that infringes on the patent rights of another party (the defensive strategy), or (4) they can pursue a combination of these strategies. These diverse applications can be accounted for in the model by simply treating all patent holders as being extractive, but acknowledging that exclusive and defensive patent holders charge different kinds of prices. In effect, exclusive patent holders charge royalties that no potential infringer could afford to pay. Similarly, defensive patent holders charge royalties denominated in the royalties they do not pay for other people's patents. On the other hand, extractive patent holders would prefer to get some direct revenue from their licensing targets and so will price their royalties such that at least some potential infringers can afford to pay them.

The CF-model holds that an alleged infringer will challenge the patent holder by contesting either the validity or the applicability of the patent where her utility from doing so exceeds her utility of simply accepting the license demands of the patent holder.

Challenge if:

$$
\text { UChallenge }>U_{\text {License }}
$$

This inequality can be expanded as follows:

$$
\begin{aligned}
& a\left(U_{W i n}\right)+(1-a)\left(U_{\text {Lose }}\right)>\Pi-C_{L}-I \\
& a(\Pi-L-I)+(1-a)\left(\Pi-L-I-C_{L}-C_{P}-P\right)>\Pi-C_{L}-I
\end{aligned}
$$

Expanding and restating in terms of $\mathrm{L}$ yields: 


$$
L<a C_{L}+(1-a)\left(C_{P}+P\right)
$$

\section{(Equation 1)}

In words, the model shows that an alleged infringer will challenge the patent holder if the cost of litigation (L) is less than the probability of winning (a) times the cost of the license plus the probability of losing (1-a) multiplied by the penalties associated with an unsuccessful challenge to the patent, such as increased royalty rates and enhanced damages for willful infringement $\left(C_{P}\right.$ $+P)$.

\section{Comparative Statics}

This yields useful comparative statics. ${ }^{90}$ As the probability of winning approaches total certainty, i.e., $\alpha \rightarrow 1$, the alleged infringer will challenge if litigation costs are less than the cost of licensing.

\section{Challenge if: $L<C_{L}$ as $a \rightarrow 1 \quad$ (Comparative Static 1)}

This makes sense intuitively. As successfully challenging the patent becomes more likely, the costs of an unsuccessful challenge become less important. An interesting result from Comparative Static 1 is that the alleged infringer's potential profit appears to have disappeared from the equation. But in actual fact, the alleged infringer's potential profit is still significant as determinant of $\mathrm{C}_{\mathrm{L}}$, i.e., $C_{L}=f(\Pi)$. It is difficult to estimate what the average patent license demand is, but anecdotal evidence suggests that it is significantly less than the minimum threshold costs of patent litigation. Probably the most plausible method of valuing intellectual property is known as the "income approach," which views the value of an asset in terms of the present value of the future stream of economic benefits that can be derived from its ownership. ${ }^{91}$ Under this method, royalty rates are directly tied to the profits of the alleged infringer. ${ }^{92}$ In practice, patent license

90. Comparative statics is a modeling technique used in economics and political science. Comparative statics is the formal study of how the equilibrium or optimal values of the variables in a model are affected by changes in the values of other parameters in the model. See KEVIN M. CURRIER, CoMPARATIVE STATICS ANALYSIS IN ECONOMICS (2000).

91. See Russell L. Parr \& Gordon V. Smith, Quantitative Methods of Valuing Intellectual Property, in THE NEW ROLE OF INTELlECTUAL PROPERTY IN COMmercial TRANSACTIONS 58, 68 (Melvin Simensky \& Lanning G. Bryer eds., 1994).

92. Reasonable royalties are usually determined by the application of the 
fees are frequently determined by seemingly arbitrary rules of thumb such as the " 25 Percent Rule" or reference to past industry practices. ${ }^{93}$ Each of these methods is something of a "guesstimate" 94 but it seems fair to assume that methods of valuation that were not a function of the alleged infringer's potential profit would be displaced in the market by those that were.

Although the cost of a patent license and the potential profit of the alleged infringer are closely tied, litigation costs are only weakly related to the alleged infringer's potential profit. According to a recent survey conducted by the American Intellectual Property Law Association, litigating an individual patent case is likely to cost around $\$ 650,000$ for a low valued patent and up to $\$ 4.5$ million for a higher value patent. 95 It is not surprising that parties in high stakes cases would spend more than those in lower stakes cases, but it is significant to note that litigation costs are largely insensitive to the amount in dispute below a certain threshold. ${ }^{96}$

The stickiness of the lower boundary of litigation costs means that although licensing costs will be directly related to the alleged infringer's profit potential, litigation costs will not. For example, a

"Georgia Pacific Factors." See Ga. Pac. v. U.S. Plywood, 318 F. Supp. 1116 (S.D.N.Y. 1970); see also F. Russell Denton \& Paul J. Heald, Random Walks, Non-Cooperative Games, and the Complex Mathematics of Patent Pricing, 55 RUTGERS L. REV. 1175, 1191 (2003).

93. Denton \& Heald, supra note 92, at 1190-93. The "25 Percent Rule" is the popular license valuation method which holds that a licensee should pay a royalty equivalent to $25 \%$ of the expected profit from the product that incorporates the patent being licensed. Ted Hagelin, Valuation of Patent Licenses, 12 TEX. INTELL. PROP. L.J. 423, 424 (2004).

94. Denton \& Heald, supra note 92, at 1191 (citing Robert S. Bramson, Valuing Patents, Technologies and Portfolios: Rules of Thumb, 635 PLI/PAT 465, 471 (2001)).

95. AIPLA ECON. SURVEY, supra note 41, at 22. For a patent valued at less than $\$ 1$ million over its life, the cost of discovery alone approaches $\$ 350,000$. Id. For patents valued between $\$ 1$ million and $\$ 25$ million, the average costs rise to $\$ 1.25$ million for discovery and $\$ 2$ million for complete litigation. Id. For those patents which exceed $\$ 25$ million in value, costs average $\$ 3$ million for discovery and $\$ 4.5$ million for litigation. Id. See also Bronwyn H. Hall et al., Prospects for Improving U.S. Patent Quality Via Post-Grant Opposition 8 (Nat'l Bureau of Econ. Research, Working Paper No. 9731, 2003), available at http://papers.nber.org/papers/W9731.pdf (estimating legal costs of patent litigation ranging between $\$ 500,000$ to $\$ 3$ million dollars per suit or $\$ 500,000$ per claim at issue per side).

96. Anecdotal evidence suggests that it costs about the same to litigate a $\$ 1$ million patent suit as it does for a patent suit where the amount at stake is only $\$ 500,000$. 
potential infringer contemplating challenging the validity of a patent has to expect that her litigation costs will amount to at least around $\$ 500,000,97$ assuming that her profit is a mere $\$ 1$ million and that a $5 \%$ royalty is customary in her industry. She has to weigh that $\$ 500,000$ litigation bill against a license demand of only $\$ 50,000$. By way of counter-example, if a potential infringer had an expected profit of $\$ 10$ million, a $5 \%$ royalty would lead to a license demand of $\$ 500,000$, roughly the same value as the cost of litigation. The alleged infringer is far more likely to litigate in the second scenario than in the first.

The fact that only a small proportion of patent cases actually end in a trial on the merits should not make us any more comfortable with the high cost of patent litigation. In their recent empirical study of the resolution of patent cases from 1995 to 2000, Kesan and Ball find that between four and seven percent of cases end with a final judgment in one form or other. ${ }^{98}$ However, the authors also find that a further seven to eight percent of cases are disposed of through summary judgment. The high cost of patent litigation might be less concerning if those cases that ended in summary judgment were considerably cheaper, but the evidence shows that they are not. For example, examining patent cases filed in 1997, Kesan and Ball find that the average duration of cases that terminated through a trial was just under two-anda-half years while cases from the same year that terminated through a successful summary judgment ended only about two months sooner.99 This indicates that the high cost of patent litigation is not merely a factor in those rare cases that make it all the way to a final judgment; it also affects those cases in which the defendant is able to win on summary judgment.

The inflexible nature of litigation costs at the lower boundary also means that the majority of patent holder assertions will result in licensing costs that are far less than the lower boundary of litigation, as illustrated in Graph 1. This graph depicts a density function of the distribution of potential patent cases in relation to the difference between litigation costs and licensing costs $\left(C_{L}-L\right) .100$ We suggest that the vast majority of potential infringers will face litigation costs that exceed licensing costs as

97. AIPLA ECON. SURVEY, supra note 41, at 22.

98. Jay P. Kesan, \& Gwendolyn G. Ball, How Are Patent Cases Resolved? An Empirical Examination of the Adjudication and Settlement of Patent Disputes, 84 WASH. L. REV. 237, 265-69 (2006).

99. Id. at 64 .

100. The density function depicted here is merely illustrative; profit is not necessarily normally distributed. 
represented by the shaded area on the left-hand side of the density function in the graph below.

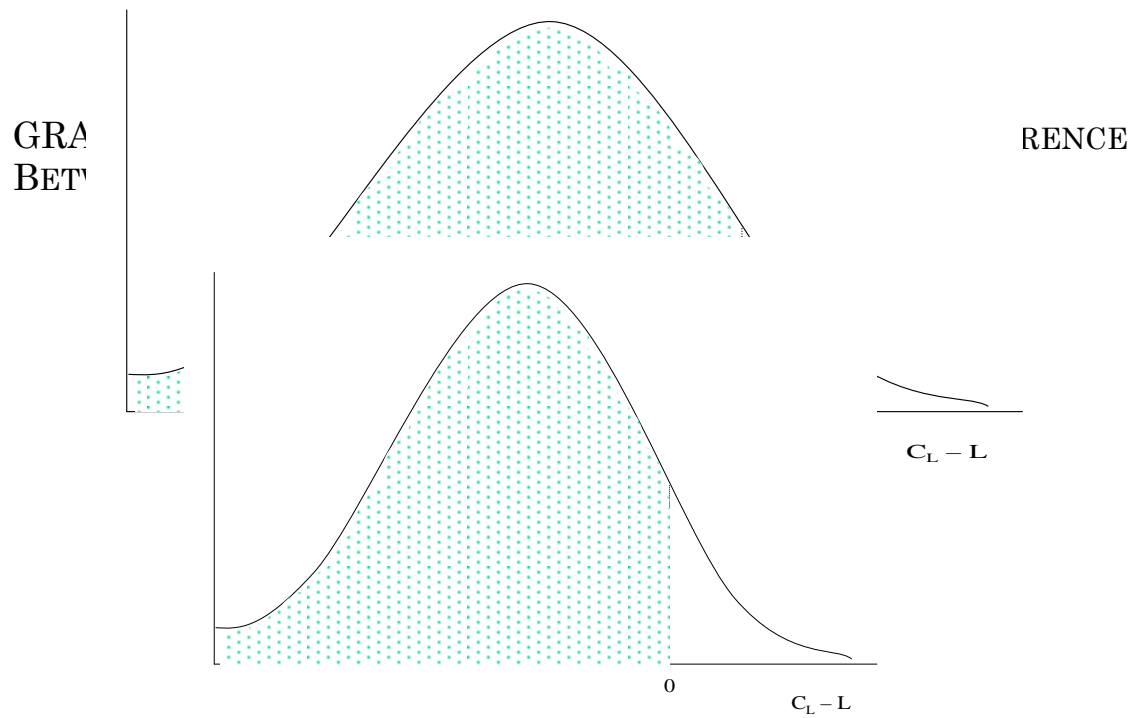

Because the majority of patent holder assertions will result in licensing costs that are far less than the lower boundary of litigation, the probability that an alleged infringer will challenge any given patent assertion is effectively zero in a large number of cases. ${ }^{101}$ Recall that the Comparative Static 1 indicated that as the probability of success approaches one, an alleged infringer would challenge if litigation costs were less than licensing costs. Graph 2 maps the predicted outcomes for a continuum of $n$ given the distribution assumptions in Graph 1.

101. Admittedly, some potential infringers may challenge in such a situation if they have a strong reputation interest in not being seen to be an easy target. Nonetheless, the simplified parameters of the CF-model probably capture the behavior of a majority of firms. 


\section{GRAPH 2: PROBABILITY OF CHALLENGE}

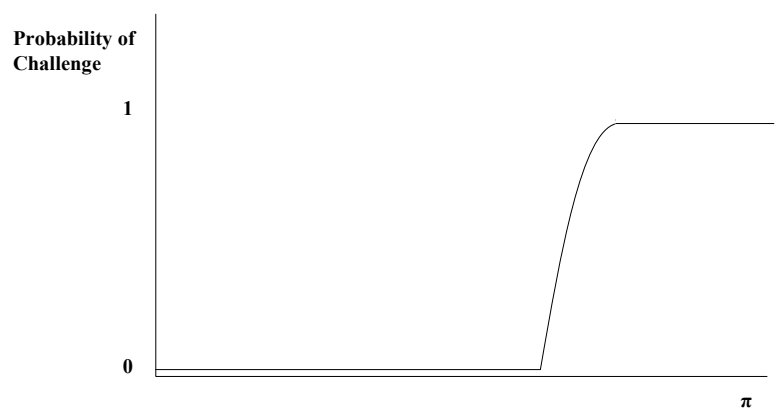

The result depicted in Graph 1 reflects anecdotal experience: at low levels of profit challenge is unlikely; at high levels of profit, challenge is very likely; there is a very small transition window in between where the probability of success is relevant to the alleged infringer's determination.

\section{Implications of the Challenger Focused Model}

The CF-model has at least six significant implications with respect to the survival of bad patents. These implications are: (1) the probability of successfully challenging the patent holder's assertion is only a significant determinant of whether an alleged infringer will challenge in a limited range of cases, (2) high litigation costs insulate bad patents from challenge, (3) the uncertainties of patent litigation insulate bad patents from challenge, (4) information asymmetries insulate bad patents from challenge, (5) challenges to bad patents are likely to be an undersupplied public good, and (6) enhanced damages and injunctions have a chilling effect on patent challenges.

\section{The Limited Relevance of the Probability of Success}

The probability of successfully challenging the patent holder in court is only a significant determinant of whether an alleged infringer will challenge in a limited range of cases. To begin with, if the cost of licensing is lower than the minimum threshold of litigation, it never makes sense to challenge. Furthermore, if the patent holder's royalty demands are high enough, it makes sense to challenge their patent in court almost regardless of the probability of success (depending on the salience of penalties for challenging unsuccessfully, discussed below). 


\section{High Litigation Costs Insulate Bad Patents from Challenge}

Bad patents can remain unchallenged as long as the royalties demanded are less than the minimum threshold of litigation costs. Patent holders are in the driver's seat in this regard because they get to determine what license fees they will demand, and they do so in full knowledge of the litigation costs faced by alleged infringers. Strategic patent holders can also effect the alleged infringer's decision to challenge by raising the costs of challenging by seeking a temporary injunction and/or establishing a reputation for demanding extravagant license fees at the conclusion of fully litigated cases. ${ }^{102}$

The costs of litigation cannot be measured purely in terms of lawyer's fees. In most cases, serious patent litigation distracts key personnel from their core responsibilities. For example, Research In Motion, the Canadian company at the center of the recent Blackberry litigation was described as "critically distracted" by the protracted litigation. ${ }^{103}$ Patent litigation can also have a negative effect on relations with outside investors, either in terms of the stock price for publicly traded companies or the availability of venture capital financing for smaller companies. The mere public announcement of a patent law suit can depress the defendant's stock price on average two to three percent, ${ }^{104}$ and sometimes much more. ${ }^{105}$ In addition, the lingering cloud of patent litigation can be especially harmful to small firms, particularly those firms with limited product diversity. ${ }^{106}$ The

\footnotetext{
102. The Supreme Court's decision in eBay Inc. v. MercExchange, L.L.C. may allow district courts to take this into account when assessing the equities of granting an injunction to patent holders. $126 \mathrm{~S}$. Ct. 1837, 1839 (2006) (holding that well-established principles of equity require a plaintiff seeking permanent injunction under the Patent Act to satisfy a four-factor test before a court may grant such relief).

103. Troy Wolverton, RIM's Up, Still on the Ropes, TheSTREET.COM, June 29, 2006 ,

http://www.thestreet.com/_googlen/tech/gamesandgadgets/10294275.html?cm_ve $\mathrm{n}=$ GOOGLEN\&cm_cat=FREE\&cm_ite=NA.

104. Sanjai Bhagat et al., The Costs of Inefficient Bargaining and Financial Distress: Evidence from Corporate Lawsuits, 35 J. FIN. ECON. 221, 223, 230-31, 239 (1994); see also Josh Lerner, Patenting in the Shadow of Competitors, 38 J.L. \& ECON. 463, 471 (1995).

105. See, e.g., James Bessen \& Michael J. Meurer, Lessons for Patent Policy from Empirical Research on Patent Litigation, 9 LEWIS \& CLARK L. REV. 1, 10 (2005) (noting that in the pharmaceutical industry losses have gone as high as $30 \%$ when news of unfavorable rulings emerged).

106. See Jean O. Lanjouw \& Josh Lerner, Tilting the Table? The Predatory Use of Preliminary Injunctions, 44 J.L. \& ECON. 573, 575-76 (2001).
} 
extraordinary length of time it takes to invalidate a patent through litigation - 8.6 years on average - exacerbates this problem considerably. 107

It is difficult to precisely measure the total costs of patent litigation, but according to one rough estimate, the total direct cost of patent litigation in the United States every year exceeds $\$ 2$ billion. 108 This figure excludes money actually paid by way of settlement or final judgment. 109 As noted above, the American Intellectual Property Law Association Economic Survey places the average cost of patent litigation at around $\$ 650,000$ for a low valued patent and up to $\$ 4.5$ million for a higher value patent. 110 As long as the minimum threshold of litigation costs remains high, bad patent holders will be able to avoid challenge by simply pitching the license demands below the cost of litigation. Any patent reform that reduced the minimum threshold of litigation costs would greatly decrease the ability of patent holders to do this. ${ }^{111}$

\section{The Uncertainties of Patent Litigation Insulate Bad Patents from Challenge}

The CF-model addresses the potential infringer's probability of successfully challenging a patent as opposed to the validity of the asserted patent per se. A number of factors combine to produce the result that the alleged infringer's probability of winning and the probability that the patent is valid are not the same thing. The alleged infringer's probability of successfully challenging the patent is not directly linked to validity because of the uncertain nature of patent litigation and the considerable risks of judicial error. As a normative matter, most patent challengers are confident that they should win; however the nature of patent litigation is such that very few can ever be sure as a predictive matter that they will successfully challenge a particular patent. All litigation is uncertain to some extent, but anecdotal reports from judges and patent lawyers indicate that

107. Lemley, supra note 22 , at 1520 . (finding that the average time from patent issuance to a final litigated decision on validity is 8.6 years).

108. Id. at 1502.

109. Id.

110. AIPLA ECON. SURVEY, supra note 41, at 22. (For a patent valued at less than $\$ 1 \mathrm{M}$ over its life, the cost of discovery alone approaches $\$ 350,000$. For patents valued between $\$ 1 \mathrm{M}$ and $\$ 25 \mathrm{M}$, the average costs rise to $\$ 1.25 \mathrm{M}$ for discovery and $\$ 2 \mathrm{M}$ for complete litigation. For those patents which exceed $\$ 25 \mathrm{M}$ in value, costs average $\$ 3 \mathrm{M}$ for discovery and $\$ 4.5 \mathrm{M}$ for litigation).

111. The effectiveness of post-grant review in this regard is discussed infra notes 253-57 and accompanying text. 
patent litigation is a particularly uncertain form of legal action. ${ }^{112}$

The Uncertainty of Claim Construction

Although there are many causes of uncertainty in patent litigation, the claim construction process is arguably the most significant. Claim construction is the critical stage of patent litigation where the court decides what the words describing the patent holder's rights actually mean. Every patent includes "one or more claims particularly pointing out and distinctly claiming the subject matter which the applicant regards as her invention."113 These claims define the boundaries of the patent holder's rights with respect to the invention. Because language is ambiguous and the path of technology is unpredictable, however, there will often be disagreements between plaintiffs and defendants as to the precise meaning of the patent claims. In the context of a patent claim, even seemingly straightforward words such as "a," "or," "to," and "when" become the subject of contested argument. In the recent Federal Circuit decision in Phillips $v$. $A W H$, the court wrestled with the question of whether the term "baffles" should be given its ordinary meaning as a "means for obstructing, impeding, or checking the flow of something" or whether it should be read restrictively based on the patent's written description to exclude structures that extend at a ninetydegree angle from the walls. ${ }^{114}$ To an outside observer this is indeed baffling.

Before 1996, claim construction was regarded as a mixed question of fact and law. However, in Markman $v$. Westview Instruments, the Supreme Court determined that claim construction was a question of law. ${ }^{115}$ By making claim construction a question of law, the effect of Markman has been to significantly increase the Federal Circuit's discretion in reviewing claim construction.

Unfortunately, the Federal Circuit has not settled on a consistent methodology for claim construction, leading to

112. See, e.g., Douglas J. Kline, Patent Litigation: The Sport of Kings, TECH. REV., Apr. 28, 2004, at http://www.technologyreview.com/ BizTech/13562/ (describing patent litigation as complex, uncertain, and expensive).

113. 35 U.S.C. $\S 112(2000)$.

114. Phillips v. AWH Corp., 415 F.3d 1303, 1310 (Fed. Cir. 2005). The patented invention pertained to modular, steel-shell panels that could be welded together to form vandalism-resistant walls. See U.S. Patent No. 4,677,798.

115. Markman v. Westview Instruments, Inc., 517 U.S. 370, 391 (1996), aff'g 52 F.3d 967 (Fed. Cir. 1995) (en banc). 
significant doctrinal instability and confusion in the lower courts. ${ }^{116}$ Indeed, Federal Circuit reversal of Markman decisions has become so routine that many judges and attorneys wonder why they bother with claim construction hearings at all. At least one district court judge has expressed the view that "the only thing that really is predictable in this area of the law is that we district judges will likely get it wrong, or at least that the Federal Circuit will say that we got it wrong." 117 Confirming this pessimism, Christian $\mathrm{Chu}$ finds that for cases involving claim construction filed between January 1, 1998, and April 30, 2000, the Federal Circuit modified the district court judge's claim interpretation in $44 \%$ of cases and reversed it in $30 \%$ of cases. 118

Ostensibly, a Markman hearing should give parties a firm understanding of what subject matter is covered by the patent at issue. Unfortunately, the significant chance that any claim interpretation made by a district court judge will be overturned or revised on appeal dilutes the effectiveness of the Markman process. In reality the scope of the patent is unclear at every stage, from issuance through litigation and appeal. In essence, parties must proceed through the decision making and litigation process with often erroneous claim and scope interpretations. ${ }^{119}$

The claim construction process is also rendered uncertain for potential infringers by the doctrine of equivalents. Under the doctrine of equivalents, a court will extend the scope of the patent holder's rights beyond the literal language of the patent claim to cover an infringing product or process that is unsubstantially different 120 or "performs substantially the same function in

116. See, e.g., R. Polk Wagner \& Lee Petherbridge, Is the Federal Circuit Succeeding? An Empirical Assessment of Judicial Performance, 152 U. PA. L. REV. 1105 (2004).

117. Honorable Kathleen M. O'Malley et al., Panel Discussion: Claim Construction from the Perspective of the District Judge, 54 CASE W. RES. L. Rev. 671, 672 (2004).

118. Christian A. Chu, Empirical Analysis of the Federal Circuit's Claim Construction Trends, 16 BERKELEY TECH. L.J. 1075, 1104 (2001); see also Cybor Corp. v. FAS Techs., 138 F.3d 1448, 1476 n.16 (Fed. Cir. 1998) (en banc) (Rader, J., dissenting) (noting that $37.3 \%$ of all claim constructions reversed in whole or in part since Markman I); Kimberly A. Moore, Are District Court Judges Equipped to Resolve Patent Cases?, 15 HARV. J.L. \& TECH. 1, 2-3 (2001) ("District court judges improperly construe patent claim terms in $33 \%$ of the cases appealed to the Federal Circuit.").

119. See Moore, supra note 118, at 2-3. ("In the absence of a route for expedited appeal of claim construction, district courts are forced to proceed with lengthy and expensive patent litigation based on their frequently erroneous claim construction.").

120. Sage Prods. v. Devon Indus., 126 F.3d 1420, 1423 (Fed. Cir. 1997). 
substantially the same way to obtain the same result." 121 The doctrine of equivalents is intended to protect the patent holder from "unscrupulous copyists" who would otherwise evade a patent holder's rights by making minimal modifications to the patented product or process. ${ }^{122}$ However, in reality the doctrine of equivalents probably does more to protect patent holders from the incompetence of their attorneys than anything else. The Supreme Court argues that the inherent ambiguity of language and the unpredictable path of technological innovation require some flexibility be extended to patent holders in the form of the doctrine of equivalents. ${ }^{123}$ However, as the Supreme Court acknowledged, the doctrine of equivalents itself exacerbates the ambiguity of claim language. ${ }^{124}$ As Josh Sarnoff explains, the modern doctrine of equivalents extends a patent's scope beyond questions of identity of "whether the product or process is an embodiment of the claimed category" to the open-ended question of similarity. ${ }^{125}$

The doctrine of prosecution history estoppel neutralizes the expansive effect of the doctrine of equivalents with respect to claims that have been narrowed during the course of patent prosecution. ${ }^{126}$ Under this doctrine, a patentee who narrows her claims at an earlier stage of litigation is estopped from later arguing that the subject matter covered by the original, broader claim that was nothing more than an equivalent.127 However, prosecution history estoppel itself is limited and uncertain. Consequently, although prosecution history estoppel might in

121. Graver Tank \& Mfg. Co., Inc. v. Linde Air Prods. Co., 339 U.S. 605, 608 (1950) (quoting Sanitary Refrigerator Co. v. Winters, 280 U.S. 30, 42 (1929)).

122. Id. at 607.

123. Festo Corp. v. Shoketsu Kinzoku Kogyo Kabushiki Co., 535 U.S. 722, 731-732 (2002).

124. Festo, 535 U.S. at 732 . ("the doctrine of equivalents renders the scope of patents less certain."); see also Joshua D. Sarnoff, Abolishing the Doctrine of Equivalents and Claiming the Future After Festo, 19 BERKELEY TECH. L.J 1157 (2004) (arguing for the abolition of the doctrine of equivalents).

125. Id.

126. Festo, 535 U.S. at 727 (noting that when the patentee responds to the rejection by narrowing her claims, this prosecution history estops him from later arguing that the subject matter covered by the original, broader claim was nothing more than an equivalent).

127. See id. at 733-34 ("When, however, the patentee originally claimed the subject matter alleged to infringe but then narrowed the claim in response to a rejection, he may not argue that the surrendered territory comprised unforeseen subject matter that should be deemed equivalent to the literal claims of the issued patent."). 
some senses be described as an antidote to the expansive effect of the doctrine of equivalents, it is by no means an antidote to the uncertainty and confusion that equivalents add to the already uncertain arena of claim interpretation.

\section{The Presumption of Validity}

A second significant cause of uncertainty in patent litigation is the Federal Circuit's interpretation of the presumption of validity. According to the Federal Circuit, a defendant seeking to invalidate a patent must do more than cast significant doubt on the patent's validity; she must prove by "clear and convincing evidence" that the patent is invalid. ${ }^{128}$ Although the current Patent Act clearly establishes that an issued patent carries a presumption of validity, ${ }^{129}$ it is only by virtue of case law that this presumption has been elevated to the high standard of clear and convincing evidence. This heightened standard of proof might make sense if patents were subject to a more rigorous system of examination, but given the very limited nature of patent examination at the Patent Office, it is particularly hard to defend as a matter of principle. ${ }^{130}$

The clear and convincing evidence standard increases a potential challenger's uncertainty because, although in theory a defendant could simply factor the heightened standard into her risk calculations, the practicality of doing so is another matter entirely. Even if the alleged infringer possesses what she believes to be "killer" prior art - for example, something that shows that the supposed invention had already been described in a printed publication well before the patent owner's claimed invention date - she must still ask herself whether this evidence will meet the gold standard of clear and convincing evidence. It is entirely possible that a reasonably competent patent examiner would find that the prior art anticipated the invention, but that a jury faced

128. See, e.g., Kegel Co. v. AMF Bowling, Inc., 127 F.3d 1420, 1429 (Fed. Cir. 1997) (invalidity must be established by facts supported by clear and convincing evidence).

129. 35 U.S.C. § 282 (2000) (providing in relevant part that, "[a] patent shall be presumed valid. Each claim of a patent . . . shall be presumed valid independently of the validity of other claims . . . . The burden of establishing invalidity of a patent or any claim thereof shall rest on the party asserting such invalidity."); see also New England Braiding Co. v. A.W. Chesterton Co., 970 F.2d 878, 882 (Fed. Cir. 1992) ("The presumption acts as a procedural device which places the burden of going forward with evidence and the ultimate burden of persuasion of invalidity at trial on the alleged infringer.").

130. See supra, Part II-A. 
[Vol. 8:1

with the same evidence would be unconvinced.131 Given that juries in patent cases are comprised of lay people who are unfamiliar with both the relevant law and the relevant technology, it is hard to know confidently ex ante whether the most convincing evidence in the world will actually prove to be clear and convincing in a court room setting. This intuition is borne out in studies of jury decisions in patent cases, which indicate that patent owners are significantly more likely to win at jury trials than otherwise. ${ }^{132}$

As the MercExchange, L.L.C. v. eBay, Inc. case illustrates, once a bad patent issues it is much easier to convince the Patent Office of its error than it is to defend an allegation of infringement at a jury trial. ${ }^{133}$ Although eBay lost on the merits in federal court, 134 it was far more successful in inter partes reexamination in the Patent Office. In January 2005, the Patent Office issued an initial ruling rejecting all of the claims contained in MercExchange's online auctions patent. 135 In March 2005, the Patent Office issued an initial ruling rejecting all of the claims contained in the MercExchange electronic consignment systems patent. 136 Then in May 2005, the Patent Office issued an initial ruling rejecting all of the claims contained in the MercExchange multiple database searching. ${ }^{137}$ These were all patents that eBay had already been found to have infringed in its jury trial in the Eastern District of Virginia. ${ }^{138}$

\section{The Effect of Uncertainty}

The uncertainty of patent litigation is significant because it reduces the alleged infringer's expectation of successfully challenging a bad patent. Put simply, the alleged infringer may

131. See infra notes $134-38$ and accompanying text.

132. See Kimberly A. Moore, Judges, Juries and Patent Cases: An Empirical Peek Inside the Black Box, 99 MICH. L. REV. 365, 368 (2000) (concluding that juries are significantly pro-patentee in suits for infringement).

133. See eBay Inc. Annual Report (Form 10-K), at 30 (Feb. 24, 2006).

134. MercExchange, L.L.C. v. eBay, Inc., 275 F. Supp. 2d 695 (E.D. Va. 2003), aff'd in part, rev'd in part, 401 F.3d 1323 (Fed. Cir. 2005).

135. See eBay Inc., Annual Report (Form 10-K), at 30 (Feb. 24, 2006).

136. Id.

137. Id.

138. Note that the Federal Circuit also invalidated all claims asserted against eBay and its subsidiaries arising out of the multiple database search patent, but reversed the district court's order granting summary judgment in eBay's favor regarding the auction patent. MercExchange, LLC v. eBay, Inc., 401 F.3d 1323, 1330 (Fed. Cir. 2005). 
have a well founded objective belief that a patent is invalid, but she can never be very sure of what the patent claims will be taken to mean or how much evidence will be required to overcome the clear and convincing evidence standard. This uncertainty clearly disadvantage risk averse parties and it also makes threats by patent holders to pursue litigation more credible because almost no assertion of rights by a patent holder is too far-fetched.

\section{Information Asymmetries Insulate Bad Patents from Challenge}

Information asymmetries insulate bad patents from challenge by deterring alleged infringers from challenging bad patents through the extra informational costs the assymetries impose. An essential problem with bad patents is differentiating them from good patents. When an alleged infringer receives a threat letter, she may have very little information upon which to assess its merits. In contrast, the patent owner generally has much greater knowledge of the validity and scope of her patent. She knows things such as the amount of effort that was made to research the prior art before the patent was filed, her success in extracting license fees from other targets, and the strength of the patent in light of the known prior art. She is also familiar with the patent's prosecution history - including any narrowed claims.

These information asymmetries are such that, at least at the early stages, a weak lawsuit may be difficult to distinguish from a strong lawsuit. An alleged infringer can do a number of things to investigate the quality of a patent that is threatened against her: she can hire lawyers to research the patent, she can hire engineers to research the technology, and/or she can gather information on her own through public and private sources. All of these activities may change her evaluation of how likely she is to successfully challenge the patent holder, but only by increasing the alleged infringer's information costs. Furthermore, some information asymmetries can only be overcome through discovery, which means spending several hundred thousand dollars on litigation.

5. Challenges to Bad Patents are Likely to be an Undersupplied Public Good

As several commentators have observed, the Supreme Court's Blonder-Tongue Laboratories, Inc. $v$. University of Illinois Foundation decision creates an ironic public good problem for any individual who seeks to challenge the validity of a patent. ${ }^{139}$

139. 402 U.S. 313, 350 (1971) (holding that a finding of patent invalidity 
Although an alleged infringer must bear the whole burden of pursuing her claim of invalidity, if she wins she must share the benefits of her labor with the whole world, including all her competitors. ${ }^{140}$ This suggests that unless alleged infringers can find some method of coordinating, they will not supply the optimum level of resistance to the demands of patent owners. ${ }^{141}$

A related problem is that in some markets, the alleged infringer's utility from successfully challenging a patent may be overstated by the CF-model explored in this section. Some alleged infringers will be able to simple pass royalty costs through to the consumer, as long as their competitors are also subject to the same costs. ${ }^{142}$ Furthermore, some alleged infringers may use the threat of patent litigation as an opportunity to raise their rivals' costs by settling patent disputes early at a discount. ${ }^{143}$ If two parties are involved in patent litigation, and both realize that the invalidation challenge will be successful, each party actually has an incentive to settle the litigation through licensing. The patent holder's incentive is obvious due to Blonder-Tongue: if she settles with the defendant, she maintains some chance of enforcing the patent against future defendants. ${ }^{144}$ Not quite so obvious is the fact that the alleged infringer's incentive to settle can be just as compelling, even if her expectation of victory is high. ${ }^{145}$ An alleged infringer who settles cheaply cannot only avoid sharing her victory with her competitors, she can actually impose a higher cost on those competitors if the appearance of settlement

during litigation applies to all, not just to the benefit of the challenging party). A public good is a good which is both non-rivalrous and non-excludable. Nonrivalrous goods can be consumed by one person without reducing the consumption of others. Non-excludable goods cannot be effectively fenced off so as to prevent others from enjoying them. Lighthouses, sunsets and national defense are common examples of public goods. See Paul A. Samuelson, The Pure Theory of Public Expenditure, 36 REV. ECON. \& STAT. 387, 387 (1954); see also Matthew Sag, Beyond Abstraction: The Law and Economics of Copyright Scope and Doctrinal Efficiency, 81 TUL. L. REV. 187, 193 (2006).

140. Miller, supra note 22, at; John R. Thomas, Collusion and Collective Action in the Patent System: A Proposal for Patent Bounties, 2001 U. ILL. L. REV. 305,333 . Note that non-infringement is not necessarily a public good because it may only be the unique activities of an individual that are in fact non-infringing.

141. Miller, supra note 22, at 668-673 ("forced sharing undermines an alleged infringer's reason for fighting the patent case to the finish- especially if the patent owner offers an attractive settlement.").

142. Farrell \& Merges, supra note 22, at 943.

143. See id. at $954-55$.

144. See id. at 968 .

145. See id. at 955-56. 
increases their perception of the validity of the patent. ${ }^{146}$

In their article examining incentives to challenge and defend patents, Farrell and Merges point to the case of Gilbert Hyatt's negotiations with North American Philips Corporation as an example of how settlement may be leveraged in infringement proceedings. ${ }^{147}$ Gilbert Hyatt was a non-manufacturing patent holder who sought royalties from manufacturers in the LCD industry. Many of the targeted competitors considered litigation, but Phillips Corporation chose to settle the dispute early, in return for beneficial terms. ${ }^{148}$ As part of the settlement, Phillips agreed to help Hyatt extract royalties from other competitors in the field. ${ }^{149}$

Joseph Miller highlights a different example ${ }^{150}$ of the incentive-to-settle using the Amazon.com "one-click" patent case against Barnesandnoble.com. ${ }^{151}$ The district court found Amazon.com's “one-click" patent valid and issued an injunction against Barnesandnoble.com's use of that feature on its website. However, the Federal Circuit later vacated the preliminary injunction and concluded that Barnesandnoble.com had "mounted a substantial challenge to the validity of the patent." 152 While not formally deciding the invalidity of the patent, the Federal Circuit remanded the decision back to the district court with what amounted to a step-by-step explanation of how and why the district court was to invalidate the patent. 153 Instead of pursuing the almost certain invalidation of Amazon.com's patent in the district court, Barnesandnoble.com settled the case, leaving the patent on the books as a credible threat against future booksellers who may have sought to compete with Amazon.com or Barnesandnoble.com. ${ }^{154}$

The combined effect of the public good nature of challenging a patent and the pass-through problem means that not only will potential infringers have sub-optimal incentives to challenge a

146. Later licensees will typically pay greater licensing fees than those who were early to the table.

147. Farrell \& Merges, supra note 22, at 970 n. 32.

148. Philips Licenses Hyatt's Microcomputer Patents, PATENT WoRLD, Dec. 1991 / Jan. 1992, at 15.

149. Id.

150. Miller, supra note 22.

151. Amazon.com v. Barnesandnoble.com, Inc., 73 F. Supp. 2d 1228 (W.D.

Wash. 1999), vacated, 239 F.3d 1343 (Fed. Cir. 2001).

152. Amazon.com v. Barnesandnoble.com, Inc., 239 F.3d 1343, 1347 (Fed. Cir. 2001).

153. Miller, supra note 22, at 671-72.

154. Id. at 672 . 
patent in the first place, but that even when they do it will almost certainly be in their interests to accept a settlement at some stage before a final judgment is entered. Consequently, even if bad patents are initially challenged, we should not be confident that potential infringers will pursue those challenges to completion.

\section{The Chilling Effect of Enhanced Damages and Injunctions}

The CF-model set forth in the previous section ${ }^{155}$ shows that the penalties associated with an unsuccessful challenge become increasingly significant as the probability of successfully challenging the patent falls. Since its formation, the Federal Circuit has tended to exacerbate these penalties through its increased willingness to order preliminary and final injunctions, ${ }^{156}$ award enhanced damages for willful infringement, ${ }^{157}$ and its greater flexibility in calculating patent damages in general. 158

The possibility of a preliminary injunction can have a substantial chilling effect on a potential infringer's willingness to pursue litigation. The effect of a preliminary injunction has been described as "the financial equivalent of nuclear winter" because of the economic hardship and disruption it imposes on defendants. ${ }^{159}$ Furthermore, settlements and royalties negotiated in the shadow of an injunction are likely to be distorted where the patent relates only to a small component of some larger product (or service) but has the ability to hold-up the entirety. 160

Despite the Federal Circuit's recognition that a preliminary injunction is "a drastic and extraordinary remedy that is not to be routinely granted," 161 the court now routinely issues preliminary injunctions ${ }^{162}$ in patent infringement cases. ${ }^{163}$ In a 1983 case,

155. See supra Part II. B.2.

156. See Lanjouw \& Lerner, supra note 106, at 575-76.

157. See Underwater Devices Inc. v. Morrison-Knudsen Co., 717 F.2d 1380, 1389 (Fed. Cir. 1983) (imposing an affirmative duty on potential infringer with actual notice of patent holder's rights to exercise due care to determine whether or not she is infringing those rights).

158. See Roger D. Blair \& Thomas F. Cotter, Rethinking Patent Damages, 10 TEX. INTELL. PROP. L.J. 1, 2 (2001).

159. Michelle Armond, Introducing the Defense of Independent Invention to Motions for Preliminary Injunctions in Patent Infringement Lawsuits, 91 CAL. L. REV. 117, 120 (2003) (citing Brenda Sandburg, Trolling for Dollars, SAN FRANCISCO RECORDER, July 30, 2001, at 1).

160. See Lemley \& Shapiro, supra note 38.

161. Intel Corp. v. ULSI Sys. Tech., 995 F.2d 1566, 1568 (Fed. Cir. 1993).

162. The court's authority with respect to preliminary injunctions is found in 
Smith International, Inc. v. Hughes Tool Co., the Federal Circuit held that an immediate irreparable harm to the patent holder should be presumed whenever the validity and continuing infringement of the patent had been established. 164 Since then, the court has further stated that "[t]he presumption of irreparable harm [now] acts as a procedural device which places the ultimate burden of production on the question of irreparable harm onto the alleged infringer." 165 This stance is inconsistent with the Supreme Court's decision in $e B a y,{ }^{166}$ and will likely be reversed in the near future.

The distorting effect of the threat of treble damages and attorney's fees for willful infringement is widely recognized. According to Federal Circuit case law, the application of treble damages and attorney's fees is appropriate where an infringer had "actual notice of [the plaintiff's] patent rights" and failed "to exercise due care to determine whether or not [she was] infringing" upon those rights. 167 However, the Federal Circuit's broad interpretation of "actual notice" makes this a significant risk. 168

\section{DifFEREnTIAL IMPACT AND THE Challenger FocUsed MODEL}

The CF-model illustrates that it is easy for bad patents to go unchallenged because of certain structural features of modern patent litigation. High litigation costs, uncertainty in litigation, information asymmetries, the public good problem, and the enhanced penalties of losing a court challenge all deter alleged infringers from mounting a challenge to the validity of the patent holder's rights. The cumulative effect of these factors is that the overall incentive for any given potential infringer to challenge a patent is often very weak, even if the probability that the patent is invalid is very high.

The CF-model predicts that an alleged infringer will challenge the patent holder if the cost of litigation is less than or

35 U.S.C. $§ 283$ (2005) (“[C]ourts having jurisdiction of cases under this title may grant injunctions in accordance with the principles of equity to prevent the violation of any right secured by patent ....").

163. Lanjouw \& Lerner, supra note 106, at 575-76.

164. 718 F.2d 1573, 1581 (Fed. Cir. 1983).

165. Reebok Int'l Ltd. v. J. Baker, Inc., 32 F.3d 1552, 1556 (Fed. Cir. 1994)

(citing Roper Corp. v. Litton Sys., Inc., 757 F.2d 1266, 1272 (Fed. Cir. 1985)).

166. See eBay Inc., 126 S. Ct. 1837.

167. Underwater Devices Inc., 717 F.2d 1380, 1389 (Fed. Cir. 1983). Enhanced damages are provided for in 35 U.S.C. $§ 284$ (2000).

168. See infra Part III.B.2. 
equal to the probability of winning multiplied by the cost of the license plus the probability of losing multiplied by the penalties associated with an unsuccessful challenge to the patent such as increased royalty rates and enhanced damages for willful infringement. Or, in terms of the notation,

\section{Challenge if: $L<a C_{L}+(1-a)\left(C_{P}+P\right)$}

(Equation 1)

All other things being equal, the higher litigation costs rise, the less likely an alleged infringer will be to challenge. As noted above, when probability of success is very high, the most important factor determining whether an alleged infringer will challenge is the ratio of litigation costs to licensing costs. If patent holders can keep their royalty demands at less than the cost of litigation, alleged infringers are unlikely to challenge, no matter how confident they are of winning. If the minimum threshold for litigation is several hundred thousand dollars, keeping patent royalty demands below this amount is easy for the patent holder to do. If the minimum threshold for litigation was considerably less, as it would be under the system of post-grant review set forth in Part IV, it would be very difficult for the holders of bad patents to rely on licensee capitulation. 169

As discussed in the previous section, the CF-model shows that the alleged infringer's prospects of success are often not significant in deciding whether to challenge a patent. Furthermore, even where the prospects of success are a significant factor in the alleged infringer's decision making process, they are only indirectly related to the validity of the underlying patent because of the uncertainties of patent litigation and information asymmetries. This is an important insight of the CF-model, but it is also important to understand that the lack of relevance of the validity of the underlying patent applies equally to good patents as to bad patents. Much of the reform literature advocates reducing the structural disincentives to challenge bad patents without acknowledging the role these features play in protecting good patents. The same factors that insulate bad patents from challenge are also a significant component of the value of all patents - whether they are good or bad.

We cannot be assured that all reforms that make patents easier to challenge will in fact have a differential impact on bad

169. See infra Part IV. 
patents because, under the current system, the holders of good patents have almost as much to fear from a challenge to the validity of their patents as bad patent holders. This may seem counter-intuitive, but recall that the label "bad patent" is not synonymous with invalid patent. ${ }^{170}$ Bad patents are those which are asserted to cover products or activities that no reasonable fact finder could find they did in fact cover - either because the patent was obviously invalid, or because the patent claims were obviously too narrow to support such an assertion.

Figure 1, below, represents four patents on a sliding scale of patent validity. The closer a patent is to the left hand side of the scale the more likely it is to be upheld by a court. Consider the following four patents; Patent $A$ has a 95\% chance of being found to be valid, Patent $B$ has $60 \%$ chance, Patent $C$ has a $50 \%$ chance and Patent $D$ has a $5 \%$ chance. ${ }^{171}$ As illustrated in Figure 1, Patent $D$ is clearly a bad patent. In contrast, although Patents $B$ and $C$ may ultimately be found invalid if subject to litigation, they are not bad patents. ${ }^{172}$ Many good patents will turn out to be invalid (or not infringed) once put to the test of litigation because of the vagaries of claim construction and other shifts in patent doctrine. Furthermore, a certain percentage of valid good patents are likely to be incorrectly invalidated (or found not infringed) due to judicial error. Reforms that uniformly lower the cost of litigation or make patents easier to challenge will not only place greater pressure on Patent $D$; they will also significantly affect the value of Patent $B$ and Patent $C$ which are not bad patents.

\section{FIGURE 1: SLIDING SCALE OF PATENT VALIDITY}

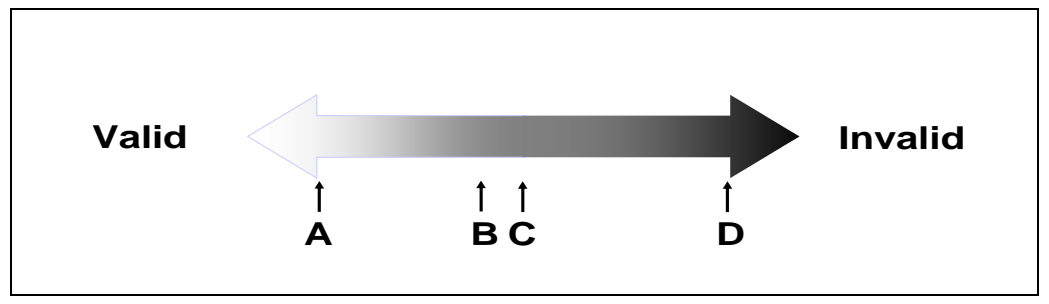

170. See supra Part I.B-1.

171. Figure 1 is constructed in terms of patent validity, however, it could also be redrawn in terms of the likelihood that a particular patent claim covered the alleged infringer's business: i.e. while the infringer has a $95 \%$ chance of being found to infringe Patent $A$, it only has a $5 \%$ chance of being found liable for infringing Patent $D$.

172. Again, the analysis is the same for hyper-assertion. 
The strong form of the differential impact test requires that any change to the patent system will devalue Patent $D$, but will not significantly effect the value of Patents $A, B$ and $C$ as represented in Figure 1. Differential impact favors reforms that will expose patents that are very likely to be invalid (or hyperasserted) to greater scrutiny, but recognizes that even the holders of good patents have a lot to lose from patent litigation. The CFmodel is very useful for explaining why bad patents survive, but in order to identify reform proposals that will reduce the value of bad patents without affecting the value of good patents, we need a model that focuses on the patent holder's incentive to assert bad patents rather than the alleged infringer's incentive to challenge them. In the next section we present an assertion focused model ("AF-model") which does just that.

\section{E. AN ASSERTion Focused ModeL}

In this section we present a new model for analyzing patent reform proposals. Instead of focusing on the potential infringer's incentive to challenge a patent, this new model focuses on the patent holder's incentive to assert her patent, including the relationship of the incentive to assert to the quality of the underlying patent. We begin with the proposition that a rational patent holder will assert her rights so long as the expected value of assertion is greater than the expected cost.

Variable Definitions:

$$
\begin{aligned}
\mathrm{Y}= & \text { Probability of target accepting a license. }{ }^{173} \\
\Pi= & \begin{array}{l}
\text { Profit to patent holder from licensing the } \\
\text { patent. }
\end{array} \\
\mathrm{T}= & \begin{array}{l}
\text { Cost to patent holder to locate and engage } \\
\text { potential licensees (a.k.a. targets). }
\end{array} \\
\mathrm{R}= & \begin{array}{l}
\text { Cost to patent holder from retaliation by the } \\
\text { target. }
\end{array} \\
\delta= & \text { Probability of retaliation by target. }
\end{aligned}
$$

The patent holder's utility in asserting her patent is a

173. $\mathrm{Y}$ is the reciprocal of $\alpha$ in the CF-model. See supra Part II.B.2. 
function of the cost of finding a target (T), the probability that the target will accept a license $(\mathrm{Y})$, the licensing revenue the patent holder will derive if the target accepts the license (п), and the expected cost of retaliation ( $\delta \mathrm{R}) .{ }^{174}$

Utility function:

The patent holder's utility in asserting her patent can be expressed in terms of the notation as follows:

$$
U_{\text {Assert: }} \gamma(\Pi-T)-(1-\gamma)(T+\delta R)
$$

In other words, when a patent owner persuades a target to accept a license, she gains licensing fees which must be off-set against the cost of identifying and engaging with the target; when a patent owner fails to persuade a target to accept a license, she loses her investment in identifying and engaging with the target and suffers the consequences of any retaliatory actions that her assertion may provoke.

The possibility of retaliation is the cornerstone of this model. Every assertion of right by the patent holder carries with it some possibility that the target will retaliate. When a patent holder sends an infringement notice to an alleged infringer, she hopes that the target will agree to her demands without complaint. However, with each new potential licensee the patent owner also faces a risk that the target will not only try to evade paying license fees, but that it will also attempt to reduce or entirely eradicate the commercial value of the patent. The most obvious form of retaliation a target can inflict is to bring an action for declaratory judgment that the patent is both invalid and not infringed. Another more subtle form of retaliation includes publicly defying the patent, thus forcing the patent owner to either sue or implicitly acknowledge it is unable to enforce its claims.

The patent holder will assert if

$$
\begin{aligned}
& U_{\text {Assert }}>0 \\
& \gamma(\Pi-T)>(1-\gamma)(T+\delta R)
\end{aligned}
$$

Restated in terms of the expected cost of retaliation yields:

174. $\delta$ is the probability of retaliation by the target, and $R$ is the cost of retaliation, thus $\delta \mathrm{R}$ is the expected cost of retaliation. 
[Vol. 8:1

\section{Assert if: $\delta R<(\gamma \pi-T) /(1-\gamma)$}

\section{(Equation 2)}

The most important implication of this model is that where targeting costs are low and the prospect of retaliation is small, this inequality will almost always be met. Accordingly, a rational patent holder will broadly assert her patent in these circumstances, even where the probability that any individual target will accept a license is low. In many cases patent holders have an incentive to broadly assert patent rights regardless of the low quality of the patent or the low probability that any one potential infringer will accept a license. Indeed, as the AF-model predicts, technology industry leaders frequently complain that they are deluged with meritless patent assertions. ${ }^{175}$

\section{F. Implications of the Assertion Focused Model For PATENT REFORM}

To reiterate, the AF-model provides some interesting insights for patent reform. The model predicts that where targeting costs are low and the expected cost of retaliation is small, a rational patent holder will broadly assert her patent, even where the probability that a target will accept a license is low. The model also indicates that a patent holder's incentive to assert her patent increases as the target's probability of accepting a license increases. Accordingly, patent reform can have a differential impact on bad patents in any one of three ways: (1) increasing the targeting costs of bad patent holders without increasing the targeting costs of good patent holders, (2) reducing the probability that alleged infringers targeted by bad patent holders will accept a license without reducing the probability that alleged infringers targeted by good patent holders will accept a license, or (3) increasing the expected cost of retaliation for asserting a bad patent without increasing the expected cost of retaliation for asserting a good patent. This final possibility - engineering expected cost of retaliation for asserting a bad patent - appears to be the most promising option for the reasons that follow.

First, while creating a differential impact with respect to

175. See, e.g., Edited and Excerpted Transcript of the Symposium on Ideas into Action: Implementing Reform of the Patent System, 19 BERKELEY TECH. L.J. 1053, 1153 (2003). One general counsel lamented "if I had a dollar for every letter that either we never heard from again or never responded when we wrote to them, we would be rich." Id. at 1153 
targeting costs is theoretically possible, none of the reforms surveyed in this article (nor any others we are aware of) would seem likely to have this effect.

Second, the potential to create a differential impact in terms of the probability that alleged infringers targeted by bad patent holders will accept a license is limited because the patent holder often has a significant degree of control with respect to that variable. Patent holders who can choose the identity of their targets have a substantial degree of control over the probability of retaliation. A target's propensity to accept a license will depend in part on the cost of the license; the more the patent holder demands from the target, the more likely it is that the target will refuse to pay. ${ }^{176}$ A potential infringer's propensity to accept a license will also depend on how effectively it has been targeted; the more accurately the patent holder identifies her potential targets and the more effort she expends to make her threats of litigation credible, the more likely it is that a target will opt to license. For extractive patent holders, both of these are factors within the patent holder's control. So, in terms of the notation, $\gamma=$ $f(\Pi, T)$. Furthermore, sophisticated patent holders will seek out those targets with the lowest probability of retaliation and/or the lowest ability to inflict significant retaliatory costs and send them an "offer to negotiate a license" letter. Once a few licensees have signed up, the patent holder can expect $\mathrm{Y}$ (the probability that the target will accept a license) to rise and $\delta$ (the probability of retaliation by the target) to fall among new targets as word gets out that other licensees have signed up or the patent holder develops a market reputation. This reputation can be as much for litigiousness as for the quality of their patents.

Third, creating a differential impact in terms of the probability that alleged infringers targeted by bad patent holders will accept a license also has limited potential because of uncertainty and information asymmetries. In an ideal world a target's willingness to accept a license would depend on the nature of the patent assertion - they would reject bad patent assertions and seek to invalidate them through litigation. However, as the CF-model indicates, uncertainty and information asymmetries discourage alleged infringers from challenging patents. In fact, because uncertainty and information asymmetries have a leveling out effect, they increase the target's willingness to accept a license from bad patent holders and

176. This is subject to the obvious caveat that the holders of bad patents must not seek license fees so low that they tip off the target that the patentee's claims are unsupportable. 
reduce their willingness to accept a license from good patent holders. ${ }^{177}$

In the face of substantial information asymmetries, a target is likely to over-estimate the validity of bad patents and underestimate the validity of good patents. In other words, if all patents look the same to an alleged infringer, its willingness to accept a license will be unrelated to the underlying quality of the patent. If the holder of a good patent knows the patent to be good, it is in her best interests to communicate this information to the target. Alternatively, if the holder of a bad patent knows her assertions are lacking in foundation, it is in her best interests to restrict any information about the quality or scope of the patent. But the problem faced by good patent holders is that whatever steps they take to communicate the quality of their patent to the target will be imitated by bad patent holders. It is difficult to conceive of reforms to the current system that reduce $\mathrm{Y}$ for bad patent holders without similarly affecting good patent holders. ${ }^{178}$

Finally, changing the patent system to have a differential impact on the probability that alleged infringers targeted by bad patent holders will accept a license is unrealistic; however, reforming the system in a manner that allows the expected value of retaliation faced by good patents to diverge from that of bad patents is more feasible. The introduction of a system of postgrant review will expose all patent holders to an increased threat of challenge - in terms of the model it will increase $\delta$. But what is significant is that, as long as the system is designed correctly, the expected costs of retaliation will fall far more heavily on bad patent holders than on good patent holders. In terms of the model, $R_{\text {Bad }}>R_{\text {Good. }}{ }^{179}$

We expect post-grant review to impose higher costs on bad patents because it allows patents to be reviewed for obvious errors at an early stage. In our view, post-grant review will be most effective if it operates as an alternative to litigation that seeks to weed out the most clearly improvidently granted patents, as opposed to seeking to identify every single improvidently granted patent. If this high threshold of invalidity is adhered to validly granted patents should not be at substantial risk. ${ }^{180} \mathrm{We}$

177. See infra Part III.C.3.

178. Id.

179. Id.

180. See infra Part IV.B. 
also expect post-grant review to impose higher costs on bad patents because good patents will actually be advantaged by postgrant review. Post-grant review will reduce uncertainty and information asymmetries relating to patent quality because patents that survive post-grant review are more likely to be taken seriously in the market than ones that have never been tested. In this way, post-grant review provides a signal of patent quality for good patents that bad patent holders face great costs in imitating.

\section{G. The Relevance of Economic Models to Patent Reform}

In Part I of this article we argued that Congressional action on patent reform should be targeted towards implementing the reforms most likely to have a differential impact on bad patents. Ideally, patents are issued to the creators of new, useful, and nonobvious inventions to give them an incentive to invest resources in innovation where they would not do so otherwise. However, a considerable number of patents are issued that do not meet the standards of patentability and do not encourage investment in innovation. In this Part, we sought to explain both the origin and survival of bad patents. Specifically, we discussed why the Patent Office issues invalid and uncertain patents and why some patent holders see value in asserting patent rights that no reasonable judge or jury would uphold.

The economic models discussed in this Part confirm experiences that are often reported anecdotally by patent practitioners. First, alleged infringers often have weak incentives to challenge bad patents (even if they are fairly sure they are invalid). Second, patent holders have strong incentives to overclaim their rights. Understanding these phenomena of the modern patent system is central to determining which proposed reforms are likely to have a differential impact on bad patents.

Commentators who rely solely on a variation of the CF-model may have overlooked the fact that the same structural impediments that shield bad patents from litigation also protect good patents from litigation. Thus, in spite of the fact that most of the reform literature sees lowering the cost of challenging patent validity as an unqualified good, we are more neutral. Reforms that make all patents easier to challenge will not necessarily have a differential impact on bad patents.

Because the CF-model does not necessarily tell us which reforms are likely to have a differential impact on bad patents, we developed a second economic model focused on the patent holder's incentives to assert her patent rights. The AF-model indicates that where targeting costs are low and the prospect of retaliation 
is small, a rational patent holder will broadly assert her patent even where the probability that any individual target will accept a license is low. The AF-model is particularly useful in determining which proposed reforms are likely to have a differential impact on bad patents. It indicates that exposing patent holders to retaliation when they assert their patents has the potential to create a differential cost between good patent holders and bad patent holders. ${ }^{181}$

Part III applies the insights generated by these economic models to a wide range of patent-system reforms that are currently under consideration.

\section{PART III. APPLYING THE DIFFERENTIAL IMPACT TEST}

Part I of this article explained the need for a clearer understanding of bad patents and the need for a differential impact test. The purpose of the differential impact test is to suggest which reforms to the patent system Congress should pursue as a matter of priority. As discussed, applying a test of differential impact is necessary because of the empirical uncertainty surrounding optimal patent scope and because of the apparent need for a more targeted approach to patent reform legislation. In Part II of this article we applied two economic models to suggest what kinds of changes might have a differential impact. In this Part we directly apply the differential impact test to a broad survey of patent reform proposals, including those embodied in the most recent House and Senate Bills. ${ }^{182}$

Congress has recently been invited to consider a wide range of solutions for the problems in the patent system. This subsection briefly reviews some of the major reforms under consideration. Patent law reform proposals can be divided into three main groups: examination reform, substantive doctrinal changes, and proposals to reform the structure and procedures of patent litigation. In the remainder of this section, these reform proposals are evaluated against the differential impact test.

\section{A. EXAMINATION REFORM}

The first group of reform proposals relates to the Patent

181. Further research is required to determine whether this is the basis for a true separating equilibrium.

182. These bills are no longer live, but their key proposals are likely to be put before Congress in a revised form in the near future. 
Office's process for examining and ultimately issuing patents. One of the widely perceived problems with the patent system is that too many suspect patents are issued. A simple solution appears to be improving the quality of examination, thus removing bad patents at the source.

Indeed, the Patent Office itself has taken up the cause of examination reform. It proposes significant changes, such as limiting an applicant's right to file continuations, ${ }^{183}$ streamlining the examination process by requiring applicants to designate representative claims for initial examination, ${ }^{184}$ launching an online peer review pilot project that seeks to ensure that patent examiners will have improved access to all available prior art during the patent examination process, ${ }^{185}$ and changing the rules relating to Information Disclosure Statements to encourage patent applicants to give the Patent Office the most relevant information related to their inventions in the early stages of the review process. ${ }^{186}$

The Patent Office has also recently proposed a new "accelerated examination" procedure that would offer a final decision on patentability within twelve months to applicants who meet restrictive criteria. Under the proposed rules, accelerated examination applicants must file electronically, conduct prior art searches, submit all prior art that is closest to their invention, identify all the limitations in the claims that are disclosed in the submitted references (with accurate citations to the references),

183. Changes to Practice for Continuing Applications, Requests for Continued Examination Practice, and Applications Containing Patentably Indistinct Claims, Notice of proposed rulemaking, 71 Fed. Reg. 48, 48 (proposed Jan. 3, 2006) (to be codified at 37 C.F.R. pt.1), available at http://www.uspto.gov/web/offices/com/sol/notices/71fr48.pdf. If recently proposed rule changes are adopted, applicants who wish to file any kind of continuation application will have to support that filing with "a showing as to why the amendment, argument, or evidence presented could not have been previously submitted." Id. The Patent Office hopes that the proposed change will "improve the quality of issued patents, making them easier to evaluate, enforce, and litigate" and give "the public a clearer understanding of what is patented." Id.; see also Mark A. Lemley \& Kimberly A. Moore, Ending Abuse of Patent Continuations, 84 B.U. L. REV. 63, 96-118 (2004) (discussing elimination or limitation of continuation applications).

184. Changes to Practice for the Examination of Claims in Patent Applications, 71 Fed. Reg. 61, 61 (proposed Jan. 3, 2006) (to be codified at 37 C.F.R. $\quad$ pt. 1$), \quad$ available at http://www.uspto.gov/web/offices/com/sol/notices/71fr61.pdf.

185. See Noveck, supra note 71.

186. See Changes to Information Disclosure Statement Requirements and Other Related Matters, 71 Fed. Reg. 36323 (July 10, 2006), available at http://www.uspto.gov/web/offices/com/sol/notices/71fr38808.pdf. 
explain the relationship of the prior art to the invention on a claim by claim basis, and limit the patent to three independent claims and no more than twenty claims in total. Accelerated examination applicants must also agree to have an interview with the patent examiner. ${ }^{187}$

To the extent that a reform proposal merely calls for the optimization of current resources, we consider it to be neutral in terms of our differential impact analysis. ${ }^{188}$ The harder question is whether more resources should be allocated to patent examination. The problem with simply throwing more money at patent examination is that it is unclear how much additional resources will reduce the problem of bad patents. As Mark Lemley argues, while improving examination for the small fraction of issued patents that are actually asserted would clearly be worthwhile, improving examination for the other 95\% would largely be a waste of resources. ${ }^{189}$

Spending more money on patent examination requires having more money to spend in the first place. If we assume that we do not want to divert the necessary funds away from health, education or national security, finding more funds for patent examination implies either increasing patent filing fees or simply reviewing fewer patents and thus significantly increasing patent pendency. In that event, raising the quality of examination may do as much harm to the potential holders of good patents as it would to holders of bad patents. Good and bad patentees are each likely to be deterred from filing applications as the cost rises and/or the pendency increases. 190 We take no position on whether raising the quality of patent examination in general is justified, but we do observe that it is hard to justify from the perspective of the differential impact test. 191

187. Changes to Practice for Petitions in Patent Applications To Make Special and for Accelerated Examination, 71 Fed. Reg. 36323, 36324 (June 26, 2006), available at http://www.uspto.gov/web/offices/com/sol/notices/71fr36323.pdf.

188. Reforms such as limiting the applicant's right to file continuations, requiring applicants to designate representative claims for initial examination, online peer review and accelerated examination procedures are within the Patent Office's discretion to implement and do not require legislative action. They are thus not the focus of this paper.

189. Lemley, supra note 22, at 1511.

190. It is possible that increasing the cost of obtaining a patent would have a greater chilling effect on bad patents than good ones and thus have a weak differential impact.

191. It is possible that increasing the cost of obtaining a patent may have a weakly differential impact, if a higher quality of examination would give an 
In addition to changes initiated by the Patent Office, the House and Senate Patent Reform Bills both propose three significant changes to Patent Office procedure. First, both the House and the Senate Bills propose changing the American "first inventor" rule to the international standard of "first inventor to file."192 Second, both Bills also provide for pre-grant opposition allowing third parties to submit references to the examiner during prosecution of a patent application. ${ }^{193}$ If pre-grant opposition is expanded as proposed, third parties who are concerned that a piece of relevant prior art has been overlooked by the applicant will no longer have to wait for the patent to issue. They will be able to submit that prior art six months after the patent is first published. Third, the House Bill provides for the mandatory publication of patent applications. ${ }^{194}$ Most patent applications are already published after eighteen months under the current regime; the significant change contemplated by the House Bill is to make publication mandatory. ${ }^{195}$

The differential impact analysis we have explored in this article is generally supportive of the examination reforms proposed under the House and Senate Bills. Adopting the international practice of awarding the patent to the first inventor to file an application is clearly a long overdue rationalization of the current system. One advantage of a first-to- file system is that it reduces uncertainty by prompting earlier disclosure of the invention to the public. ${ }^{196}$ A first-to- file system is also advantageous because it would harmonize U.S. patent law with that of most foreign countries. ${ }^{197}$ Such harmonization would consolidate the ownership of patent rights across national boundaries and allow for more streamlined examination internationally. Also, it should be recognized that there is no significant downside to adopting a first-to-file system because the

advantage to good patents over bad patents.

192. Patent Reform Act of 2005, H.R. 2795, 109th Cong. § 3 (2005); Patent Reform Act of 2006, S. 3818, 109th Cong. § 3 (2006).

193. Patents Depend on Quality Act of 2006, H.R. 5096, 109th Cong. § 4 (2006).

194. H.R. $5096 \S 3$.

195. Id

196. But see Kieff, supra note 22, at 96. (arguing that the increased incentive to file early in a first to file system may cause inventors to file premature and ultimately invalid patent applications).

197. 151 CONG. REC. E1160 (daily ed. June 8, 2005) (statement of Rep. Berman); see also Toshiko Takenaka, The Best Patent Practice or Mere Compromise? A Review of the Current Draft of the Substantive Patent Law Treaty and a Proposal for a "First-To-Invent" Exception for Domestic Applicants, 11 TEX. INTELL. PROP. L.J. 259, 266-71 (2003). 
[Vol. 8:1

first to file is usually judged to be the first to invent as well. ${ }^{198}$ Admittedly, adopting a first-to-file system is not likely to have a differential impact on bad patents. But given that it reduces cost and uncertainty for all patent holders at no cost to the public, we endorse this particular reform.

The second examination reform proposed under the House Bill is pre-grant opposition. ${ }^{199}$ Allowing third parties to submit references to the examiner during the prosecution of a patent application should improve the quality of decision making for two reasons. First, patent examiners will have access to information that they may have otherwise overlooked. Second, the fact that a third party has submitted prior art signals to the examiner that the patent is potentially significant and that she should ensure a thorough examination.

Allowing pre-grant opposition should have a differential impact because third parties are likely to target patents that are commercially relevant and may be easily invalidated by prior art. Pre-grant opposition is likely to filter out some bad patents before they are even issued. It should also ensure that the claims of patents that are issued are more carefully scrutinized. Nonetheless, the overall impact of pre-grant opposition may be limited by its reliance the ability of third parties to monitor the stream of patent applications as they are published. Furthermore, such a system would have to be monitored by the Patent Office to ensure that it was not abused to simply delay the issuance of valid patents in particular industries.

The third examination reform proposed under the House Bill is mandatory publication of all patent applications after eighteen months. ${ }^{200}$ Until relatively recently, patents filed in the United States would remain secret until the day they were issued by the Patent Office. This system was advantageous to patent applicants because it allowed them to maintain trade secret rights in the event that their application was ultimately unsuccessful. In 1999, Congress passed the American Inventors Protection Act, which required that a patent application be published eighteen months

198. Gerald J. Mossinghoff, The U.S. First-To-Invent System Has Provided No Advantage To Small Entities, 84 J.PAT \& TRADEMARK OFF. SOC'Y 425, 427 (2002) (stating that between 1983 and 2000, the first to file won 1917 of the 2858 interference cases).

199. Patents Depend on Quality Act of 2006, H.R. 5096, 109th Cong. § 4 (2006).

200. H.R. 5096, § 3 . 
after its earliest filing date. ${ }^{201}$ However, the significance of that reform was undermined by the broad exception for applicants who did not file their patent application in any foreign publishing country. Those applicants were allowed to opt out of automatic publication. ${ }^{202}$ The relevant provisions of the House Bill will close this loophole and make publication after eighteen months the rule for all patent applications. ${ }^{203}$ Mandatory publication would improve the patent system by reducing the possibility that third parties are taken by surprise by an issued patent.204 If a company is aware that a patent that relates to on their business may issue in the near future, it has the option of negotiating a license with the applicant or to design around the patent. 205

Mandatory publication is likely to have a differential impact on bad patents because secrecy is probably more helpful to bad patent holders than to good ones. Patents made available to the public during the examination process are more likely to be subject to scrutiny than those that are not. Earlier exposure and pre-grant opposition will enable interested third parties to supplement the examination of the Patent Office, which should lead to fewer potentially bad patents being issued.

\section{B. DOCTRINAL REFORM}

The FTC, the NAS and large sections of the academic community have suggested numerous doctrinal reforms for patent law. Some significant proposals include: raising the threshold of non-obviousness, ${ }^{206}$ narrowing the scope of willful infringement, ${ }^{207}$ lowering the burden of proof on patent alleged

201. American Inventors Protection Act of 1999, Pub. L. No. 106-113, § 4502, 113 Stat. 1501, 1501 (1999) (amending 35 U.S.C. $§ 122(b)$ ).

202. 35 U.S.C. $\S 122(b)(2)(B)(2000)$.

203. H.R. $5096 \S 3$.

204. But see Lemley \& Shapiro, supra note 38 (finding that, in some cases where an upstream component is patented, royalty overcharges arise even if the patent holder approaches the downstream firm before that firm has designed its product).

205. Id

206. See FTC REPORT, supra note 4, at Executive Summary 10 ("Recommendation 3: Tighten Certain Legal Standards Used to Evaluate Whether A Patent Is 'Obvious."'); see also NAS REPORT, supra note 24, at 87 (suggesting a reinvigoration of the non-obviousness standard).

207. See FTC REPORT, supra note 4, at Executive Summary 16 ("Recommendation 9: Enact Legislation to Require, As a Predicate for Liability for Willful Infringement, Either Actual, Written Notice of Infringement from the Patentee, or Deliberate Copying of the Patentee's Invention, Knowing It to Be Patented."); see also NAS REPORT, supra note 24, at 117 (recommending limiting the subjective elements of patent litigation). 
infringers from the daunting "clear and convincing evidence" test to a more rational "preponderance of the evidence" test, ${ }^{208}$ and curtailing the availability of injunctions for patent infringement. 209

Differential impact analysis has some interesting implications for doctrinal reform. What may be most surprising is that differential impact analysis is largely unsupportive of reform to substantive patent doctrines. Although narrowing the scope of willful infringement is clearly advantageous in terms of differential impact, reforms such as raising the threshold of nonobviousness, lowering the burden of proof on patent challengers, and curtailing the availability of injunctions for patent infringement cannot be recommended on this basis. This does not necessarily mean that such reforms are ill-advised, but it does imply that they should not be a legislative priority at this time.

\section{Raising the Threshold of Non-Obviousness}

The meaning and implementation of the non-obviousness standard has attracted a great deal of attention in the context of bad patents. It is settled law that a patent should not be granted if "the subject matter [of the invention] as a whole would have been obvious at the time the invention was made to a person having ordinary skill in the art." 210 However, several decisions of the Federal Circuit have combined to limit the capacity of the Patent Office to reject a patent on the grounds of obviousness. ${ }^{211}$ For example, the Federal Circuit does not allow a patent examiner to reject an application using general knowledge, common sense or the examiner's own understanding or experience unless that knowledge is "articulated and placed on the record," 212 a difficult standard to achieve in some cases. This

208. See, e.g., FTC REPORT, supra note 4, at Executive Summary 8 ("Recommendation 2: Enact Legislation to Specify that Challenges to the Validity of a Patent Are To Be Determined Based on a 'Preponderance of the Evidence."').

209. See, e.g., Michael J. Meurer, Controlling Opportunistic and AntiCompetitive Intellectual Property Litigation, 44. B.C. L. REV. 509, 511 (2003). A significant area not addressed here is the scope of the experimental use defense. See generally Katherine J. Strandburg, What Does The Public Get?: Experimental Use And The Patent Bargain, 2004 WIS. L. REV. 81 (2004).

210. 35 U.S.C. $§ 103($ a) (2000).

211. Bronwyn H. Hall \& Dietmar Harhoff, Post-Grant Reviews in the U.S. Patent System-Design Choices and Expected Impact, 19 BERKELEY TECH. L.J. 989, 999 (2004).

212. See, e.g., In re Lee, 277 F.3d 1338, 1345 (Fed. Cir. 2002) (general knowledge); see also In re Zurko, 258 F.3d 1379, 1386 (Fed. Cir. 2001). 
requirement is intended to prevent the examiner from indulging in hindsight, but it can also tie the hands of the Patent Office such that it is unable to "reject something just because it's stupid." 213

Whether or not the Supreme Court or the Federal Circuit should raise the current standards of patentability relating to obviousness (or patentable subject matter) is the subject of legitimate debate. ${ }^{214}$ The Supreme Court's much anticipated decision in KSR $v$. Teleflex is expected to address the question of whether a finding of obviousness should require proof of some suggestion or motivation to combine prior art references. ${ }^{215}$ The doctrinal arguments in favor of reforming the Federal Circuit's approach may be persuasive. It is difficult, however, to justify the reform on the basis of the differential impact test set forth in this article because changing the standards of patentability changes what constitutes a bad patent. As a policy analysis tool, differential impact only makes sense if we take the existing standards of patentability as given. However, taking a broader view, we believe that imposing a more rigorous standard in relation to non-obviousness (and patentable subject matter) would more closely link patent rights to activity that confers a benefit on society.

\section{Narrowing the Scope of Willful Infringement}

The essential problem with the willful infringement doctrine is that it allows a patent holder to carefully craft an "offer to license" letter which puts a potential infringer on notice for willful infringement but does not expose the patent to judicial review. This oddity arises because the Federal Circuit sets a high

213. See supra note 1.

214. See, e.g., Brief for Intellectual Property Law Professors as Amici Curia in Support of Petitioner at 2, KSR Int'l Co. v. Teleflex Inc., 119 F. App'x 282 (Fed. Cir. 2005) (No. 04-1350) (arguing that the Federal Circuit's current approach to non-obviousness is at odds with the statutory language, inconsistent with Supreme Court precedent, and contrary to the goals of the patent system). But see Christopher A. Cotropia, Patent Law Viewed Through an Evidentiary Lens: The "Suggestion Test" as a Rule of Evidence 2 (Tul. Pub. L. Res. Paper No. 06-03, 2006), available at http://ssrn.com/abstract=893965 (finding that the Federal Circuit has not narrowed the suggestion test).

215. KSR Int'l Co. v. Teleflex, Inc., 126 S. Ct. 2965 (2006). The Federal Circuit had held that a claimed invention cannot be held "obvious," and thus unpatentable under 35 U.S.C. § 103(a), in the absence of some proven "teaching, suggestion or motivation' that would have led a person of ordinary skill in the art to combine the relevant prior art teachings in the manner claimed.". KSR Int'l Co. v. Teleflex Inc., 119 F. App'x 282, 289-90 (Fed. Cir. 2005), cert. granted, 126 S. Ct. 2965 (2006). 
threshold for standing to seek a declaratory judgment, ${ }^{216}$ but imposes a low threshold for the notice required to trigger willful infringement. 217 Before a potential infringer can file a motion for declaratory judgment pursuant to 28 U.S.C. $§ 2201$, she must possess a "reasonable apprehension of suit."218 Federal Circuit case law provides that the application of treble damages and attorney's fees is appropriate where an infringer had "actual notice of [the plaintiff's] patent rights" and failed "to exercise due care to determine whether or not [she was] infringing" upon those rights. ${ }^{219}$ However, the Federal Circuit's interpretation of "actual notice" is so liberal that it can be satisfied by a company's inhouse engineers or patent attorneys learning of the patent. ${ }^{220}$

The steroidal nature of the willful infringement rule has three predictable consequences. First, a significant number of technology companies direct their personnel not to read patents. 221 As technology industry representative recently

216. See O'Hagins, Inc. v. M5 Steel Mfg., Inc., 276 F. Supp. 2d 1020, 1024-25 (N.D. Cal. 2003) (explaining standards for standing).

217. See, e.g., SRI Int'l Inc. v. Advanced Tech. Labs. Inc., 127 F.3d 1462, 1470 (Fed. Cir. 1997) (holding that actual notice for the purposes of willful infringement may be achieved without creating a case of actual controversy in terms of the declaratory judgment statute). The defects of the current doctrine of willful infringement have been thoroughly reviewed elsewhere. See, e.g., Timothy R. Holbrook, Possession in Patent Law, 59 SMU L. REV. 123, 142-45 (2006); Thomas F. Cotter, An Economic Analysis of Enhanced Damages and Attorney's Fees for Willful Patent Infringement, 14 FED. CIR. B.J. 291 (2004/2005); Mark A. Lemley \& Ragesh K. Tangri, Ending Patent Law's Willfulness Game, 18 BERKELEY TECH. L.J. 1085, 1087 (2003).

218. See O'Hagins, Inc., 276 F. Supp. 2d at 1024-25.(holding that "actual controversy" requires both "(1) an explicit threat or other action by the patentee, which creates a reasonable apprehension on the part of the declaratory plaintiff that it will face an infringement suit, and (2) present activity which could constitute infringement or concrete steps taken with the intent to conduct such activity.") (internal quotations and citations omitted).

219. Underwater Devices Inc., 717 F.2d at 1389-91. Enhanced damages are provided for in 35 U.S.C. $§ 284$ (2000).

220. See Note, The Disclosure Function Of The Patent System (Or Lack Thereof), 118 HARV. L. REV. 2007 (2005) (arguing that the Federal Circuit's development of the doctrine of willful infringement undermines the disclosure function of the patent system by deterring innovators from reading patents to protect themselves from treble damage awards in infringement suits); see also Stryker Corp. v. Intermedics Orthopedics, Inc., 96 F.3d 1409, 1414-16 (Fed. Cir. 1996).

221. Transcript of Federal Trade Commission Public Hearing on Competition and Intellectual Property Law and Policy in the Knowledge-Based Economy at 420-21 (Feb. 27, 2002) (statement of R. Jordan Greenhall), available at http://www.ftc.gov/opp/intellect/020227trans.pdf; see also Timothy Holbrook, Possession in Patent Law, 59 SMU L. REV. 123, 144 (2006) (discussing various 


\section{commented:}

[T] he penalty for so-called willful infringement makes [searching patents] a really stupid idea ... there's a penalty applied to it if you find patents that later on somebody says you infringe. You can be fined, you can be liable for triple damages. ${ }^{222}$

Second, when they cannot avoid learning about the existence of a patent, many companies will obtain non-infringement opinions in order to demonstrate their exercise of due care in avoiding infringement. ${ }^{223}$ Third, some alleged infringers settle cases they might otherwise pursue because of fear of attorneys fees and treble damages.

The possibility of willful infringement increases the penalties for unsuccessfully challenging an assertion of patent rights. Furthermore, the zone of immunity between vague assertion and actions which create a reasonable apprehension of suit encourages patent owners to broadly and indiscriminately assert their rights. In effect, patent holders who provide "notice" of their rights that falls short of the declaratory judgment standard get something for nothing - the patent holder raises the alleged infringer's expected cost of challenging the patent without increasing her own expected cost of retaliation. To quote one general counsel:

We worry about these letters because of things like the willfulness standard. It would be great if I could just say this is ridiculous and throw it in the trash can. We obviously can't do that. We engaged in a very reasoned analysis and, in some cases, we get very expensive opinions of counsel which, in some cases, sit on the shelf because you never hear again. In fact, most of the time you never hear again, but that does not mean it is free to me. We also get a lot of what I call "squirrelly" letters [which say] "We noticed that you recently announced your such and such feature. We think that you might be interested or benefited from taking a license to our portfolio." So are they accusing me of something? Well, I do not know the answer to that, but I can guarantee you if there is litigation, they are going to say they did, and I

disincentives to read patents and patent applications).

222. Transcript of Federal Trade Commission Public Hearing on Competition and Intellectual Property Law and Policy in the Knowledge-Based Economy at 677 (Feb. 28, 2002) (statement of Robert Barr), available at http://www.ftc.gov/opp/intellect/020228ftc.pdf.

223. See, e.g., Transcript of Federal Trade Commission Public Hearing on Competition and Intellectual Property Law and Policy in the Knowledge-Based Economy at 155 (Oct. 25, 2002) (statement of John R. Thomas), available at http://www.ftc.gov/opp/intellect/021025trans.pdf ("First, we've heard that it supposedly incents opinion of counsel to guide accused infringers, but in fact, it's pretty commonly known in the patent bar that most of the opinions produced by counsel are commonly known as non-infringement and invalidity opinions because that's inevitably the advice that they give."). 
am going to be dealing with that issue in litigation. ${ }^{224}$

The House Bill will have a differential impact on bad patents by aligning the standards for willfulness and standing for declaratory judgment. The House Bill eliminates the willfulness zone and reduces the incentives for patent holders to make indiscriminate "offers to license" by narrowing the application of willful infringement. The House Bill narrows the permitted grounds for finding willful infringement to cases where the patent owner presents clear and convincing evidence of one of two things. First, that the infringer either intentionally copied the patented invention with knowledge that it was patented;225 or second, that the infringer received written notice from the patentee alleging acts of infringement in a manner sufficient to give the infringer an objectively reasonable apprehension of suit on such patent. ${ }^{226}$ The proposed legislation also restricts when a patent holder can plead willful infringement such that no determination of willfulness can be made before issues of validity and infringement are determined by the court. 227 Eliminating the willfulness zone will have a differential impact because patent holders will no longer be able to raise the stakes for alleged infringers without increasing their own exposure to retaliation. This has a differential impact because bad patents are more likely to be invalidated on declaratory judgment.

\section{Eliminating the Clear and Convincing Evidence Standard}

The Federal Circuit has interpreted the Patent Act's presumption of validity for issued patents to mean that a potential infringer seeking to invalidate a patent must prove by "clear and convincing evidence" that the patent is invalid. ${ }^{228}$ This

\footnotetext{
224. Edited and Excerpted Transcript of the Symposium on Ideas into Action: Implementing Reform of the Patent System, 19 BERKELEY TECH. L.J. 1053, 112829 (2003).

225. Patents Depend on Quality Act of 2006, H.R. 5096, 109th Cong. § 6 (2006) (proposing to amend 35 U.S.C. 284). The House Bill also provides that damages for willful infringement may be awarded against a party if, "after having been found by a court to have infringed that patent, the infringer engaged in conduct that was not colorably different from the conduct previously found to have infringed the patent, and which resulted in a separate finding of infringement of the same patent." Id.

226. Id.

227. Id. Also note that the court's determination of an infringer's willfulness shall be made without a jury.

228. See, e.g., Kegel Co. Inc. v. AMF Bowling, Inc., 127 F.3d 1420, 1429 (Fed.
} 
heightened burden of proof for those wishing to challenge a patent's validity is intended to safeguard patent holders from frivolous and unsubstantiated attacks. However, the application of this high evidentiary threshold is difficult to reconcile with the realities of modern patent examination. ${ }^{229}$ We do not know what proportion of patents are wrongly issued by the Patent Office, but we do know that roughly half of all litigated patents turn out to be invalid. ${ }^{230}$ As such, the clear and convincing evidence standard is frequently considered a prime candidate for revision. ${ }^{231}$

Although we concede that the clear and convincing evidence of invalidity may have outlived its usefulness, we do not recommend simply changing to the more common preponderance of the evidence test. Lowering the standard of proof required to challenge patent validity will not necessarily have a significantly differential impact on bad patents; instead, it is more likely to decrease the value of all patents, regardless of whether they are good or bad. Arguably, lowering the burden of proof with respect to invalidity may have a weakly differential impact - that is, one that would devalue both good and bad patents but have a greater effect on bad ones. Even if this is the case, it does not provide a strong basis for doctrinal reform. Lowering the burden of proof for challenging the validity of a patent would certainly decrease the potential extortion of bad patents, but it would also devalue the patent portfolios of every good patent holder by making them more easily subject to unwarranted challenges. In Part IV of this article we propose a variable presumption of validity as an alternative to changing the standard. This would have a significantly differential impact. ${ }^{232}$

4. Curtailing the Availability of Injunctions for Patent Infringement

In eBay, Inc. v. MercExchange, the Supreme Court rejected

Cir. 1997) ("Invalidity must be established by facts supported by clear and convincing evidence").

229. See, e.g., Lemley, supra note 22 , at 1528 . The presumption of validity has little if any basis in fact. Examiners do not in fact spend long hours poring over a patent application or the prior art. They spend very little time, and far less than either the lawyers or the triers of fact in infringement cases. They regularly miss the most relevant prior art. Id., see also Mark A. Lemley et al., What to do About Bad Patents, 28 REGULATION 10 (2005-06), available at http://ssrn.com/abstract $=869826$.

230. Allison \& Lemley, supra note 49 , at 205 (stating only $54 \%$ of the patents were found valid in a population of 300 final validity decisions).

231. See FTC REPORT, supra note 4, at Executive Summary 8.

232. See infra Part IV. 
the Federal Circuit's automatic imposition of an injunction for patent infringement and held that "according to well-established principles of equity, a plaintiff [must] satisfy a four-factor test before a court may grant relief [in the form of a permanent injunction]."233 To obtain a permanent injunction a plaintiff must demonstrate:

(1) that it has suffered an irreparable injury; (2) that remedies available at law, such as monetary damages, are inadequate to compensate for that injury; (3) that, considering the balance of hardships between the plaintiff and defendant, a remedy in equity is warranted; and (4) that the public interest would not be disserved by a permanent injunction. ${ }^{234}$

If passed, the House Bill will slightly amplify the effect of the Supreme Court's ruling in eBay. The House Bill reaffirms the equitable nature of injunctions and requires judges to act "in accordance with the principles of equity" and to apply injunctions on such terms as they deem fair. ${ }^{235}$ Significantly, the House Bill provides for an automatic stay of any injunction pending appeal if the defendant is able to show that "the stay would not result in irreparable harm to the owner of the patent and that the balance of hardships from the stay does not favor the owner of the patent." 236

The arguments for and against granting injunctions in favor of non-practicing entities have been covered extensively in the legal literature and before the Supreme Court in its consideration of the eBay case. ${ }^{237}$ In terms of the differential impact test, it should be noted that the ability to obtain a final injunction adds significant negotiating leverage to good and bad patents alike. There may well be good reasons to relax the Federal Circuit's inflexible stance toward final injunctions, but this particular reform is not a high priority in terms of differential impact. ${ }^{238}$

233. eBay Inc., 126 S. Ct. at 1839.

234. Id.

235. Patents Depend on Quality Act of 2006, H.R. 5096, 109th Cong. § 8 (2006) (proposing to amend 35 U.S.C. 283). The fairness language does not appear in the rival Senate Bill.

236. Id.

237. See, e.g., Brief Amici Curiae of 52 Intellectual Property Professors in Support of Petitioners, eBay v. MercExchange, L.L.C., 126 S. Ct. 1837 (2006) (No. 05-130); Brief of Various Law \& Economics Professors as Amici Curiae in Support of Respondent, eBay v. MercExchange, L.L.C., 126 S. Ct. 1837 (2006) (No. 05-130).

238. Arguably making it more difficult to obtain preliminary injunctions may have a differential impact on bad patents. 


\section{LitigATION REFORM}

In addition to changes to Patent Office procedure and substantive patent doctrines discussed above, Congress is also being asked to consider major changes to the entire structure through which patent disputes are litigated. Again, there is a considerable array of reform proposals on the table ranging from providing incentives for third party patent bounty hunters, facilitating collective action by alleged infringers, to creating an administrative review system for determining patent validity as an alternative to district court litigation.

As discussed in Part II, the CF-model shows that the high cost of patent litigation insulates bad patents from effective challenge in many cases. The AF-model shows the patent holder's decision to assert is directly tied to the probability that their targets will retaliate and the potential harm that retaliation might cause. Both models indicate that changes to the structure of patent litigation have significant potential to affect the behavior of patent holders and potential infringers. The question we address in this section is the extent to which the litigation reform proposals currently being debated are likely to have a differential impact on bad patents.

\section{Fee-Shifting and Bounty Hunter Proposals}

The three bounty/fee-shifting proposals reviewed below illustrate the diversity of recommendations on the Congressional table. For example, John Thomas proposes encouraging third parties to assist the Patent Office in its search for invalidating prior art by rewarding them with a bounty for any relevant prior art that reads on the purported invention. ${ }^{239}$ Under the Thomas proposal, the Patent Office would publish the patent application and invite the public to submit prior art before the patent is issued. ${ }^{240}$ If application claims are rejected based on these third party submissions of prior art, the submitting party would receive a bounty determined by the Patent Office and paid by the applicant. ${ }^{241}$ As an alternative, Joseph Miller advocates a litigation stage bounty. ${ }^{242}$ Miller suggests that third parties

239. John R. Thomas, Collusion and Collective Action in the Patent System: A Proposal for Patent Bounties, 2001 U. ILL. L. REV. 305, 342 (2001).

240. Id.

241. Id.

242. Miller, supra note 22. Miller argues that the Thomas proposal occurs too early in the process and that third parties would be unable to determine whether the technology represented in the application is commercially valuable. See id. at 704 . 
should receive a bounty in situations where the "court voids a patent claim on a ground that the patentee could have prevented by diligently and candidly researching, drafting, and prosecuting its patent application." 243

Jay Kesan offers a related, but distinct proposal. Kesan proposes a one-way, pro-defendant, fee-shifting system in which the patent holder pays the costs of litigation if at least some of the patent claims are invalidated on the basis of prior art which was reasonably discoverable by the patentee during prosecution. ${ }^{244}$ Ordinarily a patent holder has very little incentive to diligently research the prior art or to submit only those claims that are likely to survive litigation stage review. However, punishing the patent holder in those cases where reasonable and diligent research would have suggested that the patent claims were invalid changes the patent holder's incentives at the time of prosecution. Patent holders who choose not to conduct thorough prior art searches either during prosecution or before attempting to enforce their patents would expose themselves to increased litigation costs if their claims prove to be invalid. 245

The fee-shifting and bounty hunter proposals outlined above effectively raise the alleged infringer's expected gains from challenging a patent, or, alternatively, lower the patent holder's expected gains from asserting her patent. The bounty hunter proposals are effectively penalties for improvident patent drafting, whereas Kesan's fee-shifting proposal constitutes a penalty for asserting an improvidently drafted patent. Both measures may have a differential impact because bad patents have a higher average probability of triggering these costs.

However, there is a risk that the fee-shifting and bounty hunter proposals might be too aggressive in their attempt to enhance the incentives to challenge patents. Penalizing improvident patent drafting should stimulate patent holders to improve patent quality at the application stage, but the resulting increased expenditure is not necessarily efficient given that the commercial value of the innovation will often be unknown at the

243. Id. at 707. Miller's bounty system would thus incorporate challenges to best mode, enablement, and possibly inequitable conduct by the patent applicant before the PTO. Miller would seek to overcome the problems he identifies in the Thomas proposal by tying the amount of the bounty awarded to the patent holder's past profits. This would provide incentives to challenge only those patents likely to be commercially valuable. $I d$. at 711-12.

244. Kesan, supra note 22 , at 787, 795.

245. Id. at 795 . 
time of drafting. If these penalties are reserved for those patent holders who fail to look for and disclose even the most readily available prior art, then they should not trouble good patent holders too much. But, if such penalties are more broadly applied, they may substantially raise the legal costs of all patent prosecution in a way that discriminates more in relation to the budget constraints of the patentee than the quality of their patents. Indeed, reforms centered on bounties and fee shifting may simply create disparities according to patent holder risk tolerance as opposed to their identity as either good or bad patent holders. ${ }^{246}$

Furthermore, larger companies are unlikely to view the bounty payoff as a significant revenue stream. Therefore, their incentives to challenge patents will remain unchanged with respect to the current system. Smaller niche firms may form solely for the purposes of submitting prior art in anticipation of bounty payouts. This would be mitigated by the requirement of submission fees, but still leaves open the possibility of continuing patent attacks by non-interested parties based solely on financial reward incentives. Such a scenario inevitably leads to a lowquality of third party prior art submissions and thus an increase of costs across the board for all patent prosecution.

Jay Kesan's fee-shifting proposal is more promising than the bounty hunter proposals in terms of its differential impact. Ordinarily, a patent holder has very little incentive to diligently research the prior art or to submit only those claims that are likely to survive litigation stage review. Fee-shifting would attack this problem by effectively punishing the patent holder in those cases where reasonable and diligent research would have suggested that the patent claims were invalid.

Fee-shifting should have two significant effects. First, the prospect of fee-shifting changes the patent holder's incentives at the time of prosecution. The risk of suffering an adverse award of costs should make at least some patent applicants consider performing a more thorough prior art search during prosecution and/or before attempting to enforce the patent. 247 Second, the prospect of fee-shifting should also reduce the incentives of potential infringers to settle strong invalidation cases early.

Fee-shifting appears to have a differential impact because although all patent holders face slightly greater risks when they

246. Id. at 796 (acknowledging that fee shifting imposes a heavier burden on poor companies which may not be able to bear the increased costs of prosecution or pre-litigation search actions).

247. Id. at 795 . 
attempt to enforce their patents, the magnitude of those risks is tied to the quality of the underlying patent. However, it should be noted that its actual effects in the patent context are somewhat speculative. A study of the effect of fee-shifting in Florida medical malpractice cases indicates that fee-shifting both encourages those with strong cases to pursue their claims while discouraging those with weak cases. ${ }^{248}$ If this also held true for patent litigation it would mean that fee-shifting would have a clearly differential impact on bad patents. However, there are at least two caveats about fee-shifting. First, there is surprisingly little agreement among theoreticians as to the effect of fee-shifting on litigation in general. ${ }^{249}$ Second, the few empirical studies that have been performed on the effect of fee-shifting have not been in the area of patent law. It is conceivable that a study involving Florida medical malpractice litigation may have entirely different idiosyncrasies than studies of federal patent litigation. ${ }^{250}$

The Senate Bill appears to have embraced the idea of feeshifting, albeit not in the form suggested by Kesan. Section 5 of the Senate Bill requires courts to award attorneys' fees to a prevailing party in cases where the non-prevailing party's legal position was not "substantially justified." 251 The Senate Bill departs from Kesan's proposal in two ways. First, Kesan proposes a pro-defendant one-way fee-shifting scheme, whereas the feeshifting rule proposed in the Senate Bill would apply to either the patent owner or the alleged infringer. Second, the Senate Bill's threshold of lack of substantial justification means that the provision is less likely to be invoked than Kesan's standard of undisclosed prior art being reasonably discoverable by the patentee during prosecution. ${ }^{252}$

Although there are reasons to hope that fee-shifting will have a differential impact on bad patents, fee-shifting alone is not a complete solution. First, fee-shifting does nothing to address the

\footnotetext{
248. Herbert M. Kritzer, Lawyer Fees and Lawyer Behavior in Litigation: What does the Empirical Literature Really Say?, 80 TEXAS L. REV. 1943, 1949-50 (2002).

249. Id. at 1947-48 ("scholars have considered the impact of fee shifting on . . . [with] surprisingly little agreement”).

250. Id. at 1950 (Kritzer summarizes the findings of a study of the effect of fee-shifting in Florida medical malpractice cases as follows: fee-shifting "encourages some plaintiffs (those with strong cases) to pursue their claims while discouraging others (those with weak cases). The result is to reduce the frequency of low-merit claims.").

251. Patent Reform Act of 2006, S. 3818, 109th Cong. § 5 (2006).

252. Kesan, supra note 22 , at $787,795$.
} 
issue of delay in federal court litigation. Second, fee-shifting is only effective if patent holders have the resources to pay an award of costs. Finally, the prospect of fee-shifting may have a chilling effect on the assertion of good patents held by risk-averse entities.

\section{Facilitating Collective Action}

Carl Shapiro has suggested that one solution to the problem of bad patents is to make it easier for government agencies with an interest in consumer welfare such as the FTC, or public interest advocacy groups such as The Electronic Frontier Foundation and the Public Patent Foundation to challenge the validity of suspect patents. ${ }^{253}$ Shapiro further suggests that the antitrust authorities should make it easier for potential infringers to collectively defend their rights by "making it clear that cooperative efforts to challenge patents will generally not be considered illegal collusion, even when such efforts involve horizontal rivals who are seeking to pay less for a technological input, or license." 254

Edward Hsieh proposes facilitating cooperation among alleged infringers by allowing for the mandatory joinder of all potential defendants and thus consolidating all defendants in a single action. He argues that mandatory joinder would lower the individual defendant's costs of litigation, reduce overall litigation costs, prevent patentees from suing smaller companies first, and encourage defendants to challenge bad patents. ${ }^{255}$

Cooperative patent challenges and mandatory joinder are both aimed at solving collective action problems relating to patent litigation. The difference between the two proposals is that the first merely facilitates collective defense by potential infringers, the second is actually coercive. From the perspective of differential impact, the problem with facilitating collective action is that there is nothing to suggest that potential infringers will act collusively to defeat bad patents more than they will act collusively to defeat good patents.

253. See Carl Shapiro, Patent System Reform: Economic Analysis and Critique, 19 BERKELEY TECH. L.J. 1017, 1040-41 (2004); see also, Lemley \& Shapiro, supra note 89.

254. Shapiro, supra note 253 , at 1041.

255. Hsieh, supra note 89. 


\section{Post-Grant Review}

The FTC, the NAS and a wide array of commentators have urged Congress to authorize the Patent Office to administer a system of post-grant review of patent validity (post-grant review). ${ }^{256}$ Post-grant review would supplement the current third party and inter-partes reexamination systems, which are rarely used because of their prejudicial estoppel effects. 257 The Patent Act provides that any issue raised by a challenger during reexamination cannot be revisited in a later trial involving that challenger. ${ }^{258}$ This means that any potential infringer who tries to invalidate a patent through reexamination must be willing to risk that the Patent Office will decide in its favor. The challenger has no opportunity to litigate any argument or prior art evidence used in reexamination should the Patent Office make a mistake. This estoppel effect makes reexamination extremely risky unless a potential infringer is already engaged in federal court litigation. ${ }^{259}$

According to its proponents, post-grant review would drastically reduce the cost of challenging bad patents and therefore help private parties fill the gaps left by an incomplete examination process. In the words of Rep. Lamar Smith, a system of post-grant review will "provide meaningful, low-cost alternatives to litigation for challenging the patent validity." 260 Senator Orrin Hatch explains the need for post-grant review as follows:

[B]y adopting a more robust post-grant review proceeding we are providing a more efficient means of challenging a patent's validity in an administrative proceeding. This is necessary to address systemic problems in our patent system, making post-grant review an essential component of any meaningful reform legislation. While there appears to be substantial agreement regarding the need for a more meaningful post-issuance review, there are strong disagreements over its specific attributes and scope. ${ }^{261}$

256. See FTC REPORT, supra note 4, at 7 (Recommendation 1); NAS REPORT, supra note 24, at 95 (Recommendation 3); see also Patents Depend on Quality Act of 2006, H.R. 5096, 109th Cong. § 2 (2006); S. $3818 \S 6$.

257. Farrell \& Merges, supra note 22, at 966 (citing only 392 ex parte reexamination requests in 2003$)$.

258. 35 U.S.C. $§ 317$ (2000).

259. Farrell \& Merges, supra note 22, at 967 (noting that the broad consensus among patent experts is that the risks of reexamination are too great).

260. 151 CONG. REC. E1160 (daily ed. June 8, 2005) (statement of Rep. Smith).

261. 152 CONG. REC. S8804-01, S8830 (daily ed. Aug. 3, 2006) (statement of 
Post-grant review of issued patents has enormous potential to discourage and devalue bad patents without undermining the value of good patents in three ways: (i) post-grant review will provide a low cost method of challenging patents and thus prevent bad patent holders from hiding behind the high cost of federal court litigation; (ii) post-grant review will increase the expected cost of retaliation for asserting a bad patent without (significantly) increasing the expected cost of retaliation for asserting a good patent; and (iii) post-grant review will reduce uncertainty and information asymmetries relating to patent quality.

First, by reducing the cost of challenging the validity of an issued patent in some cases, post-grant review will make it more difficult for bad patent holders to simply rely on the high cost of federal court litigation to insulate them from challenges. Recall that the main implication of the CF-model was that the higher litigation costs rise, the less likely an alleged infringer will be to challenge the validity of a patent. The CF-model also demonstrated that in a large number of cases, having a high probability of successfully challenging a patent was not enough to ensure that the challenge would in fact be made. When the cost of successful litigation is more than the cost of licensing, it does not appear to make sense to challenge a patent, no matter how sure one is that such a challenge would be successful. 262 Post-grant review is significant in this context because it lowers the minimum threshold of litigation from hundreds of thousands of dollars to merely tens of thousands of dollars.

A high minimum threshold of litigation gives bad patent holders the flexibility to demand licensing fees from multiple alleged infringers that are considerable but would not make it worthwhile for any one alleged infringer to challenge the patent. For example, a patent holder can usually demand $\$ 50,000$ from twenty different alleged infringers and be fairly certain that none will challenge the patent's validity in court. However, if postgrant review allows a potential infringer to challenge the validity of the patent for a mere $\$ 25,000,263$ the patent holder can expect to encounter serious opposition from potential infringers who

Sen. Hatch).

262. Admittedly, some potential infringers may challenge in such a situation if they have a strong reputation interest in not being seen to be an easy target. Nonetheless, the simplified parameters of the CF-model probably capture the behavior of a majority of firms.

263. This is merely an example; the actual costs of post-grant review are hard to estimate at this point. 
believe that the patent has obvious defects. In theory, the holder of a bad patent could still attempt to play the same game under a post-grant review regime, but that would require demanding almost negligible royalty rates. Licensing demands that are pitched too low will immediately signal to potential infringers that the patent holder has very little confidence in her ability to enforce the patent.

Second, post-grant review will have a differential impact on bad patents by increasing the expected cost of retaliation for asserting a bad patent without increasing the expected cost of retaliation for asserting a good patent, or at least without increasing it significantly. The AF-model discussed earlier indicates that increasing the expected cost of retaliation reduces the patent holder's incentive to assert her patent.264 It follows that increasing the expected cost of retaliation for bad patents without significantly increasing the expected cost of retaliation for good patents will reduce the assertion of bad patents relative to good ones. By substantially reducing the monetary cost of challenging a patent's validity, post-grant review will expose all patent holders to an increased threat of retaliation when they assert their patent rights. However, post-grant review still has a differential impact because the expected cost of that retaliation should be much lower for good patents than for bad ones.

Post-grant review has a more significant differential impact than would be achieved by simply lowering the cost of federal court litigation. Post-grant review is different from federal court litigation for two reasons. The first is that the high cost and delay of full scale patent litigation is a significant detriment to both good and bad patent holders alike. The second is that good patent holders continue to face a significant chance of losing in federal court because of the uncertainties of litigation generally, the risk of judicial error and fluctuations in patent law doctrine. ${ }^{265}$ Figure 2 illustrates this point using the same sliding scale of patent validity as in Figure 1.266 Just as in Figure 1, the closer a patent is to the left hand side of the scale, the more likely it is to be upheld (or found to be infringed) by a court. Figure 2 depicts four patents; Patent A has a $95 \%$ chance of being found to be valid, Patent $B$ has $60 \%$ chance, Patent $C$ has a $50 \%$ chance and Patent $D$ has a $5 \%$ chance.

264. See supra Part II.E.

265. See supra Part II.D.

266. See supra note 171 and accompanying text. 
FIGURE 2(a): PATENTS AT RISK IF LITIGATED

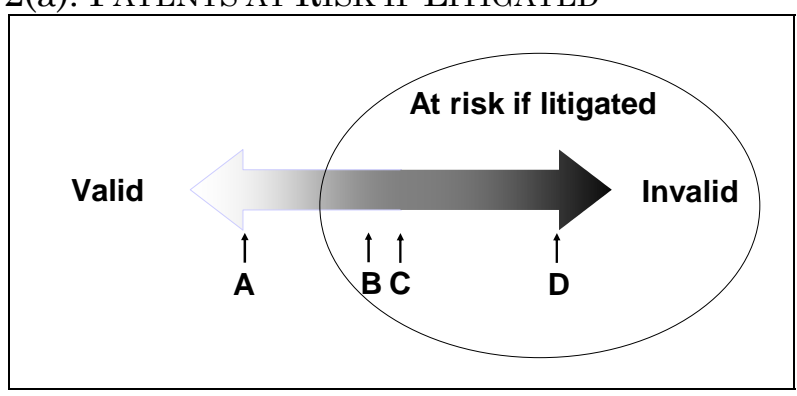

FIGURE 2(b): PATENTS AT RISK Under Post-Grant REVIEW

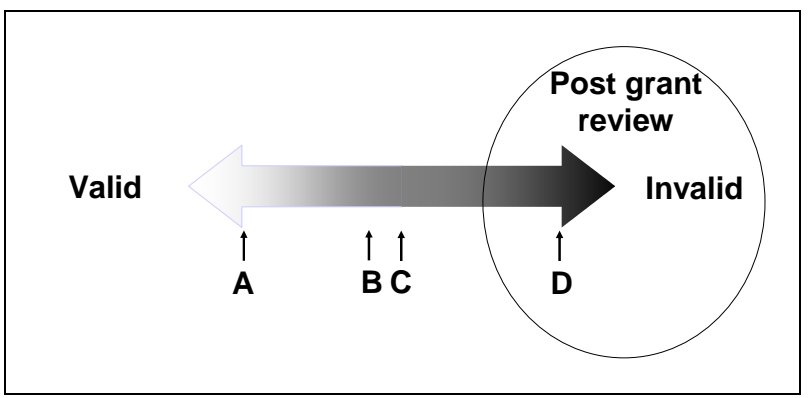

As Figure 2(a) illustrates, although Patent $D$ is far more likely to be invalidated through litigation, Patents $\mathrm{B}$ and $\mathrm{C}$ are also at risk. In contrast, as depicted in Figure 2(b), the narrower scope of post-grant review should only place Patent $D$ in jeopardy. Good patent holders should only face a very slight risk from postgrant review if post-grant review is only intended to filter out patents that clearly fail to satisfy the statutory grounds of patentability. Post-grant review, generally, will not be a viable method for determining the validity of Patents $B$ and $C$ because the information required to make such fine-grained determinations will typically not be available at such an early stage. In addition, as discussed in more detail below, the expected cost of retaliation in the form of post-grant review should be much lower for good patents than for bad ones because good patents actually benefit from being subjected to the review process.

Finally, post-grant review will have a differential impact on bad patents by reducing uncertainty and information asymmetries relating to patent quality. As discussed in relation to the CF-model, would-be patent challengers face significant 
information costs in assessing patent quality. When a firm first receives some notification that it may be infringing another person's patent rights, it needs to form a view as to both the merits of that allegation and the likelihood that the patent holder will pursue it. Obtaining this information is costly because bad patent holders will go as far as possible to imitate good patent holders in terms of the royalties they demand and their apparent willingness to go to court. Consequently, uncertainty and information asymmetries relating to patent quality have a leveling out effect; they increase the targets' willingness to accept a license from bad patent holders and reduce their willingness to accept a license from good patent holders.

Post-grant review ameliorates this problem by providing a more credible signal of patent quality. Patents that survive postgrant review are more likely to be taken seriously in the market than ones that have never been tested. If post-grant review functions as intended, it will not only expose patents that should never have been granted, it will also signal the merits of patents that are reviewed and not found invalid. Not only does post-grant review provide a way to screen out some bad patents, it also provides credible information to the market about good patents. In this way, post-grant review provides a signal of patent quality for good patents that bad patent holders face great costs in imitating. Furthermore, if the model for post-grant review we propose in Part IV of this article is adopted, patents that survive post-grant review will not only appear stronger, they will be entitled to a stronger presumption of validity in litigation.

\section{Assessing Patent Reform on the Basis of Differential IMPACT}

The purpose of this section was to directly apply the differential impact test to a broad survey of current patent reform proposals, including those embodied in the latest version of the House Bill and the Senate Bill. Before summarizing our conclusions, it is important to stress that we are not suggesting that reforms that are unlikely to have a differential impact on bad patents are necessarily ill-conceived, rather, we are simply arguing that such reforms should not be a legislative priority at this time.

Our main conclusions with respect to the differential impact potential for the reforms analyzed in this article are as follows. In applying the differential impact test to the multitude of examination reforms that have been suggested, we noted that 
proposals which simply call for the optimization of current resources should be considered to be neutral in terms of differential impact. In contrast, devoting additional resources to patent examination is unlikely to have a differential impact on bad patents that would justify the additional expenditure. We did conclude, however, that the three examination reforms proposed under the House Bill, first-to-file, pre-grant opposition and mandatory publication of all patent applications after eighteen months, are all justified under a differential impact analysis. ${ }^{267}$

Doctrinal reforms generally did not fare well when assessed against the differential impact standard. Of the four main areas of doctrinal reform reviewed, only narrowing the scope of willful infringement is strongly recommended under a differential impact analysis.

Post-grant review and other changes to the structure of patent litigation have significant potential to create a differential impact on bad patents. Specifically, we concluded that fee-shifting may encourage good patent holders to pursue their cases while simultaneously discouraging bad patent holders. Proposals relating to bounties and cooperative patent challenges did not appear to be justified in terms of differential impact. Of all the reforms surveyed, establishing a forum for the post-grant review of issued patents has the most potential to discourage and devalue bad patents without undermining the value of good patents. Post-grant review has three key advantages in this respect: (i) it will provide a low cost method of challenging patents and thus prevent bad patent holders from hiding behind the high cost of federal court litigation; (ii) it will increase the expected cost of retaliation for asserting a bad patent without significantly increasing the expected cost of retaliation for asserting a good patent; and (iii) it will reduce uncertainty and information asymmetries relating to patent quality.

\section{PART IV. MULTISTAGE POST-GRANT REVIEW}

Under the differential impact test elaborated in this article, we have proposed that the current legislative push in relation to patent reform should specifically address problems related to bad patents. To reiterate, Congress should defer consideration of reforms that attempt to either strengthen or weaken the exclusive rights of patent holders generally in favor of reforms

267. Although note that our reasoning with respect to the first-to-file recommendation is slightly different. 
that are likely to raise the costs of obtaining or enforcing bad patents significantly more than they raise the costs of obtaining or enforcing good patents.

As discussed in the previous Part, the differential impact test supports the adoption of some type of post-grant review system. ${ }^{268}$ In this Part we explain how the differential impact test not only supports the idea of post-grant review in general, but also can be applied to build a better model for post-grant review than those currently on the table. In short, looking at postgrant review through the lens of differential impact leads us to propose a very different kind of system from those embodied in the House Bill, the Senate Bill or those proposed by the FTC, the NAS and various other commentators.

There are three key differences between our proposal and other variations of post-grant review. First, we propose the adoption of a variable presumption of validity such that: (i) issued patents would only receive a weak presumption of validity (i.e. they would not be subject to the clear and convincing evidence standard); (ii) patents that have been unsuccessfully challenged in post-grant review would be entitled to a strong presumption of validity (including the clear and convincing evidence standard); and (iii) rather than automatically invalidating a patent that is successfully challenged in post-grant review, such patents would merely be weakened by attaching a presumption of invalidity.

Second, we propose a multiple stage system of post-grant review, ("MPGR") with two distinct stages in order to balance the goal of greater scrutiny for bad patents with the need to minimize potential harassment of good patents. The main benefit of postgrant review should be that it allows potential infringers a low cost opportunity to correct what they believe to be obvious errors by the Patent Office. However, if that opportunity is made too freely available, it may be overused by well resourced potential infringers to chill the assertion of good patents. Finding the right balance between lowering the cost of challenging bad patents and preventing harassment of good patents can be achieved by using multiple stages of review under the MPGR process.

Third, we propose bringing questions of claim construction into post-grant review so that both sides of the bad patent phenomenon can be addressed. Patents that should never have been issued receive most of the attention in the bad patent debate, however the hyper-assertion of vaguely worded claims

268. See supra Part III.D. 
has at least as much potential to damage the incentive function of the patent system. ${ }^{269}$ To meaningfully address the bad patent phenomenon, post-grant review must find a way to deal with patents that may be legitimate in one sense but are illegitimately asserted beyond their natural scope.

\section{A. A VARIABLE PRESUMPTION OF VALIDITY}

Differential impact analysis indicates that calls for the abolition of the clear and convincing evidence standard may be misconceived. ${ }^{270}$ While it is true that the application of the clear and convincing evidence standard in relation to patent validity is difficult to reconcile with the realities of modern patent examination, it does not seem likely that lowering the standard of proof required to challenge patent validity will have a differential impact on bad patents. The main reason for this is that the presumption of validity and the clear and convincing evidence standard together provide significant protection against adjudicative error for good patents as well as bad ones.

However, none of the arguments in favor of retaining the strong form of the presumption of validity (i.e. presumption of validity plus convincing evidence standard) require that all patents should be subject to the one evidentiary standard. As an alternative to simply keeping or abolishing the strong form of the presumption of validity, we propose the application of a variable presumption of validity tied to post-grant review. ${ }^{271}$

Under the current system an applicant can obtain a patent without definitively proving anything at the Patent Office. Nonetheless, once that patent issues, it can only be invalidated through clear and convincing evidence. ${ }^{272}$ Post-grant review

269. In Part I we explained that the term "bad patent" should be reserved for patents that are asserted to cover a product or activity that no reasonable fact finder could find it covered. See supra Part I.B.

270. See supra Part III.B.

271. Mark Lemley and his coauthors have also proposed a variable presumption of validity in a slightly different context. Their proposal is that "applicants should be allowed to 'gold-plate' their patents by paying for the kind of searching review that would merit a strong presumption of validity" but otherwise a weaker form of the presumption of validity should apply. Lemley et al., supra note 229 , at 12 . Although this may sound like a radical shift from current practice, it must be noted that current reexamination procedures allow the presumption of validity to be overcome by a preponderance of the evidence and can result in the cancellation of the patent. Consolidated Patent Rules, 37 C.F.R. $\S 1.555$ (2007). Note also, that in some pre-Federal Circuit cases, the presumption of validity was eliminated if the prior art in court was not before the Patent Office.

272. See, e.g., Kegel Company, Inc. v. AMF Bowling, Inc., 127 F.3d 1420, 1429 
provides us with an excellent opportunity to revisit the one-sizefits-all application of the presumption of validity with something that is both more rational and more nuanced.

The presumption of invalidity means that a patent that is successfully challenged would still be valid in a technical sense but that if the patent holder wished to enforce it against a potential infringer she would face an uphill battle in court. The presumption of invalidity quite literally means that the patent is presumed to be invalid as an evidentiary matter, but that if the patent holder can show, on the preponderance of the evidence, that their patent is valid and infringed, she is entitled to enforce her rights. In that case, the patent would then be entitled to the strong presumption of validity.

We propose that issued patents should generally only be entitled to a weak presumption of validity: i.e. they should be presumed valid, but could be invalidated by a preponderance of the evidence rather than the onerous clear and convincing evidence standard. Once a patent has been challenged in postgrant review and is upheld, it should then be entitled to a stronger presumption of validity. Treating reviewed and unreviewed patents differently is consistent with the differential impact approach because patents that have been unsuccessfully challenged via post-grant review (or litigation) are less likely to be bad patents. We cannot be certain that an unsuccessfully challenged patent will not later be shown to be invalid, but we can be relatively confident that such invalidation will not be easily achieved.

We further propose that rather than automatically invalidating a patent that is successfully challenged in post-grant review, such patents should merely be weakened by attaching a presumption of invalidity. This is a significant departure from the current reexamination system and from the post-grant review proposals presently before Congress. By lowering the stakes of post-grant review, the presumption of invalidity makes the lack of appeal rights and other procedural safeguards with respect to post-grant review more palatable. ${ }^{273}$

One of the advantages of merely applying a presumption of invalidity to a patent that is discredited in post-grant review is that it facilitates a streamlined process within the Patent Office

(Fed. Cir. 1997) (holding that invalidity must be established by facts supported by clear and convincing evidence).

273. See infra Part IV.D. 
that does not deprive the patent holder of due process. ${ }^{274}$ Patent holders would not be able to appeal patent review decisions, but their ability to pursue subsequent litigation should be an effective substitute. We expect that in most cases a patent holder who loses in post-grant review will see the writing on the wall and abandon attempts to enforce the patent; however, those patent holders who believe that the Patent Office has incorrectly ruled against their patent still have the option of proving the validity of their patent in litigation. In some ways, the model of post-grant review we propose here is more about information revelation than adjudication. Nonetheless, in terms of the CF-model, post-grant review will function as a low cost form of adjudication for a large number of cases, even if it is not the final forum of dispute for all controversies.

The difference between the variable presumption of validity and the current patent system is illustrated in Table 1, below. As the table makes clear, the current system is indiscriminate in that it subjects reviewed and un-reviewed patents to the same strong form of the presumption of validity. The current system also suffers in that both post-grant review and litigation can lead to exactly the same outcome, thus setting up the potential for contradictory outcomes. Our proposal adopts an escalating structure that acknowledges the differences between reviewed and un-reviewed patents as well as between post-grant review and actual litigation.

\section{TABLE 1: THE PRESUMPTION OF VALIDITY}

274. Under the current reexamination system decisions of the Patent Office are appealable to the Board of Patent Appeals and Interferences. See 35 U.S.C. $\S$ $134(2000)$. 


\begin{tabular}{|l|l|l|}
\hline & Current System & Reform Proposal \\
\hline Patent issued & $\begin{array}{l}\text { Strong Presumption } \\
\text { of Validity }\end{array}$ & $\begin{array}{l}\text { Weak Presumption } \\
\text { of Validity }\end{array}$ \\
\hline $\begin{array}{l}\text { Post-grant review } \\
\text { upholds patent }\end{array}$ & $\begin{array}{l}\text { Strong Presumption } \\
\text { of Validity }\end{array}$ & $\begin{array}{l}\text { Strong Presumption } \\
\text { of Validity }\end{array}$ \\
\hline $\begin{array}{l}\text { Post-grant } \\
\text { review/reexamination } \\
\text { goes against patent }\end{array}$ & Patent Invalidated & $\begin{array}{l}\text { Presumption of } \\
\text { Invalidity }\end{array}$ \\
\hline $\begin{array}{l}\text { Patent litigation (PH } \\
\text { loses on the issue of } \\
\text { validity) }\end{array}$ & Patent Invalidation & Patent Invalidation \\
\hline
\end{tabular}

\section{B. Multi-Stage Post-Grant Review}

One of the main fears in relation to post-grant review is that it will be subject to the same kinds of strategic abuse that plagues the current patent litigation system. Post-grant review can improve the patent system by allowing for more focused examination of patents that appear to have been improperly granted, but a badly structured system of post-grant review may also allow potential infringers to harass patent owners whose patents are not so suspect. To address this concern, we propose that post-grant review should be divided into two phases such that patent challengers have to essentially pre-qualify for the right to challenge the patent. The current patent system limits the opportunity to challenge a patent to those persons who (a) have a reasonable apprehension of being sued by the patent holder and (b) have several hundred thousand dollars to spend on federal court litigation. 275 These restrictions prevent parties without a strong direct interest from challenging bad patents. For post-grant review, we propose a very different kind of limitation on the right to challenge the validity of a patent. Namely, post-grant review should be open to any person who is able to convince the Patent Office that there is a reasonable chance that one or more of the patent claims was issued in error. Accordingly, the first stage of post-grant review should be used as a screening device according to whether the challenge rises to the level of a "substantial new question in relation to patentability." 276

275. AIPLA ECON. SURVEY, supra note 41, at 108.

276. Currently, reexamination requires a finding of a substantial new question of patentability based on the prior art submissions. See Consolidated 


\section{Stage One}

Under our proposal the first stage of post-grant review has three key features: (i) the requirement that the challenger establishes that there is a substantial new question of patentability in relation to the patent; (ii) it is conducted on an ex parte basis, without the participation of the patent holder; and (iii) the Patent Office's determination on the initial phase of the challenge would become a matter of public record.

\section{i. Substantial New Question of Patentability}

Stage One of the system of post-grant review that we propose would require any person wishing to challenge the validity of an issued patent to demonstrate to a Patent Office examiner (other than the person who examined the patent in the first place) that there is a substantial new question of patentability in relation to the patent. For example, a challenger could submit prior art that was not reviewed by the examiner and argue that the prior art demonstrated that the claimed invention was not, in fact, novel at the time the patent holder "invented" it. ${ }^{277}$

The substantial new question of patentability test clearly limits the situations in which challengers can subject a patent owner to post-grant review. One likely objection to this requirement is that it will not allow for the review of invalid patents where the examiner did consider all the relevant material, but simply misunderstood the technology. This limitation is necessary from the perspective of differential impact because post-grant review is neither intended to catch every mistake made by the Patent Office nor function as a total substitution for litigation. Pre-qualification will reduce the universe of reviewable patents down to those where errors are most likely so that an administrative system can most efficiently deal with them.

One of the main advantages of this two stage structure is that it allows a potential infringer to obtain the benefit of the Patent Office's opinion on newly surfaced art references at a very low cost. If the potential infringer is right, and there is a substantial new question of patentability, she is in a good position to reject the patent holder's demands for a license. If she is wrong, it is the patent holder who is advantaged because the Patent Office will publicly announce that, even in light of the

Patent Rules, 37 C.F.R. $\S 1.515$ (2007), MANUAL OF Patent Examining PROCEDURES § 2201 (8th ed., Rev. 2, 2004).

277. See 35 U.S.C. $§ 102(2000)$. 
challenger's prior art, the patent is nonetheless valid - all at no cost to the patent holder. The differential impact here should be obvious: bad patents are more easily challenged, whereas good patents are actually strengthened by the first stage of the MPGR process.

\section{ii. Stage One Proceedings Ex Parte}

An important feature of the first stage of post-grant review is that it takes place on an ex parte basis, without the involvement of, or possibly even the knowledge of, the patent holder. The patent holder only becomes involved in the review process if a patent examiner can be convinced that the challenger has raised an objection to the patent that merits post-grant review and that is appropriate to the post-grant review forum. Patent holders will naturally be concerned that their rights may be unfairly affected by the first stage of the MPGR process. However, excluding them from the first stage of post-grant review actually benefits them by reducing the possibility that post-grant review is used by challengers as a form of harassment. Another benefit of the ex parte nature of the first stage of MPGR is that it forces potential infringers to disclose what may be their best evidence at an early stage in the proceeding, before the patent holder has incurred any cost in defending her patent.

\section{iii. Mandatory Publication of Stage One Findings}

As previously discussed, one of the problems with relying on private parties to challenge invalid or over reaching patent assertions is that even those parties that do have the incentive to start such an action may well lack the incentive to finish it. ${ }^{278}$ Individual challengers will often be better off settling with the patent holder for a trivial amount of money than investing more resources into their challenge only to have to share their victory with all of their competitors. ${ }^{279}$ Early settlement can be efficient from the point of view of the parties immediately involved, but it means that any future challenger must begin anew. Also, assuming that the terms of settlement are kept secret, other

278. See supra Part II.C.

279. See John R. Thomas, Collusion and Collective Action in Patent System: A Proposal for Patent Bounties, 2001 U. ILL. L. REV. 305, 333 (2001) (characterizing a patent validity challenge as a public good susceptible to a free rider problem where competitors are able to freely practice the invention claimed in the invalidated patent as a result of the challenger's efforts). 
potential challengers do not get the advantage of knowing how strong the parties thought the patent was.

Under our proposal, a challenger is not forced to pursue the MPGR process to its final conclusion, but the Patent Office's stage one determination on the initial challenge would become a matter of public record. The Patent Office's findings with respect to the first stage would be published and any subsequent challenger would be entitled to use those findings in post-grant review or litigation.

What is the significance of these published findings? The patent is not invalid at this stage, ${ }^{280}$ but the first hurdle to MPGR has been cleared. From this point on, it will be easier for a third party to pick up where the initial challenger left off, even if the initial challenger is appeased by the patent holder. This reduces the early settlement problems discussed in Part II. Also, the public recording of the Patent Office's determination as to the existence of a substantial new question of patentability conveys significant information to the market about the likely quality of patent; that is, it provides a low cost method of clearly flagging at least some bad patents without raising the costs to good patent holders.

\section{Stage Two}

The second stage of MPGR consists of a review of the challenge by a review panel of the Patent Office. Ideally this review panel would consist of three experienced patent examiners, none of whom had made a decision with respect to the patent at any other time. This review would take the form of an adversarial proceeding in which any interested party would be allowed to make written submissions.

At this stage, any party - including the original challenger, the patent holder, or a new challenger - may force the continuation of the MPGR process or join the MPGR process. In the case where the original challenger does not continue the process and no new challenger picks up the process, the patent holder can remove any lingering doubts as to the validity of her patent by continuing, on their own, with arguments to the Patent Office.

\section{Claim Construction and Post-Grant Review}

The current patent system does not provide any mechanism

280. Similarly, the patent is not subject to a presumption of invalidity if our proposal for a variable presumption of validity is accepted. 
for dealing with ambiguous patent claims other than federal court litigation. A unique feature of our proposal is that it would bring questions of claim construction into post-grant review such that both invalid and hyper-asserted patents could be addressed.

Poor quality examination, ambiguity of language and the unpredictable path of technology all lead to ambiguous patent claims. In consequence, established patent holders and entrepreneurial patent collectors have an incentive to take a second look at old patents relating to one technology to determine whether they can plausibly be asserted in relation to some new technology. BT's attempt to assert patent rights in relation to Internet hyperlinks exemplifies this problem. ${ }^{281}$ Similarly, the 2004 case of Superguide Corp. v. DirecTV Enterprises addressed whether a patent relating to "a system for electronically controllably viewing updateable information" on an analog television should also be construed to cover digital television technology that was not developed until well after the patent issued. ${ }^{282}$

How can post-grant review address the over-assertion of patents that may nonetheless have a core of validity? Our proposal is that post-grant review should be tailored to allow potential infringers to negate certain claim constructions. ${ }^{283}$ For example, assume that a potential infringer has reason to be concerned about a patent whose claims could be construed to mean either $A$ or $B$, where meaning $A$ is fairly narrow and would not implicate the activities of the potential infringer but meaning $B$ is much broader and would implicate the activities of the potential infringer.

It would be advantageous if the potential infringer was able to put the issue of claim construction to the Patent Office through the process of post-grant review. However, the problem with asking the Patent Office to adjudicate claim construction is that any construction given by the Patent Office may prove to be just

281. See supra notes 53-54 and accompanying text.

282. 358 F.3d 870 (Fed. Cir. 2004); see also Mark A. Lemley, The Changing Meaning of Patent Claim Terms, 104 MICH. L. REV. 101 (2005).

283. This is analogous to the Securities and Exchange Commission's practice of issuing "no-action" letters. See U.S. Securities and Exchange Commission, No Action Letters, http://www.sec.gov/answers/noaction.htm (last visited Jan. 20, 2007) ("An individual or entity who is not certain whether a particular product, service, or action would constitute a violation of the federal securities law may request a 'no-action' letter from the SEC staff."). Michael Carroll has proposed a similar innovation with respect to the fair use doctrine in copyright law. See Michael Carroll, Fixing Fair Use (working paper, on file with authors 2005). 
as fallible as the initial claim language. In other words, any definitive claim construction rendered by the Patent Office may simply provide a second set of words that will be ambiguous and subject to the unpredictable path of technology for the remainder of the life of the patent. There is, however, a solution to this problem.

Although the Patent Office may be in no better position to say what the true meaning of patent claim should be after postgrant review than it was at the time the patent issued, it should be able to determine what the patent does not mean. ${ }^{284}$ Under our proposal, potential infringers would present the Patent Office with a negative claim construction. For example, a developer of Voice Over Internet Protocol (VOIP) technology might be concerned that a particular patent dealing very generally with packet loss might be infringed by the developer's specific techniques that deal with packet loss in the context of VOIP. ${ }^{285}$

In this example, the developer would be able to ask the Patent Office to confirm its understanding that the patent does not apply to the type of packet loss prevention used in VOIP - a proposition that the Patent Office may or may not agree with. In fact, any question of claim construction presented in this fashion should contain two distinct questions: (1) does the claim encompass the broader meaning, and (2) if so, is the claim valid? The reason for this second element is that there is an inherent link between claim scope and validity. For many patent owners broad claim construction is a mixed blessing. On the one hand, broad claims increase the likelihood that the patent will confer economic power if valid, but on the other, the broader a claim becomes, the more likely it is to be found invalid on the basis of lack of novelty, obviousness, lack of enablement, or improper written description.

Chiron v. Genentech ${ }^{286}$ illustrates this problem nicely. In Chiron the court had to decide the proper scope of the patent holder's rights with respect to the isolation/creation of monoclonal antibodies that were capable of binding with the human antigen

284. Under the current law, the Patent Office is supposed to give claims "their broadest reasonable interpretation consistent with the specification" both at the time of examination and under reexamination. Phillips v. AWH Corp., 415 F.3d 1303, 1316 (Fed. Cir. 2005); see also 37 C.F.R. § 1.75(d)(1).

285. See, e.g., U.S. Patent No. 6,016,513 (filed Jan. 18, 2000) (claiming "a method of preventing packet loss during transfer of a plurality of data packets between a network interface card and a host operating system of the computer system.").

286. Chiron v. Genentech, 363 F.3d 1247 (Fed Cir. 2004). 
associated with breast cancer. $^{287}$ The patent holder had developed a number of these antigens using hybridoma technology developed in the early 1980's. 288 Hybridoma cells are used to produce monoclonal antibodies by interacting with cells from an animal that has been challenged with the relevant antigen. ${ }^{289}$ A significant problem in medical applications of this technique is that the end product contains murine (mouse derived) antibodies that are strongly rejected by the human immune system. ${ }^{290}$ In the late 1980's scientists developed a way to overcome this problem by using recombinant DNA technology. Under this approach, DNA that encodes the binding portion of monoclonal mouse antibodies is merged with human antibodies to produce "chimeric" or "humanized" antibodies. ${ }^{291}$ These antibodies are far more useful in medical applications because of lower rates of rejection by the human immune system. ${ }^{292}$

The question for the court in Chiron was whether the patent claims covered all creation of monoclonal antibodies that were capable of binding with human antigen associated with breast cancer, or whether they were limited to those produced through the plaintiff's hybridoma technology. ${ }^{293}$ This question was significant because one of the patent holder's competitors had developed superior monoclonal antibodies through the application of recombinant DNA technology. ${ }^{294}$ Illustrating the dual nature of broad claim construction, the court ruled that the patent claims applied to both methods of producing the antibodies, but also that the patent holder had failed to meet the enablement requirements with respect to that technology. Indeed, according to the Federal Circuit, there was no way the plaintiff's main patent could have enabled chimeric antibody technology because that technology had not been invented at the relevant time. ${ }^{295}$

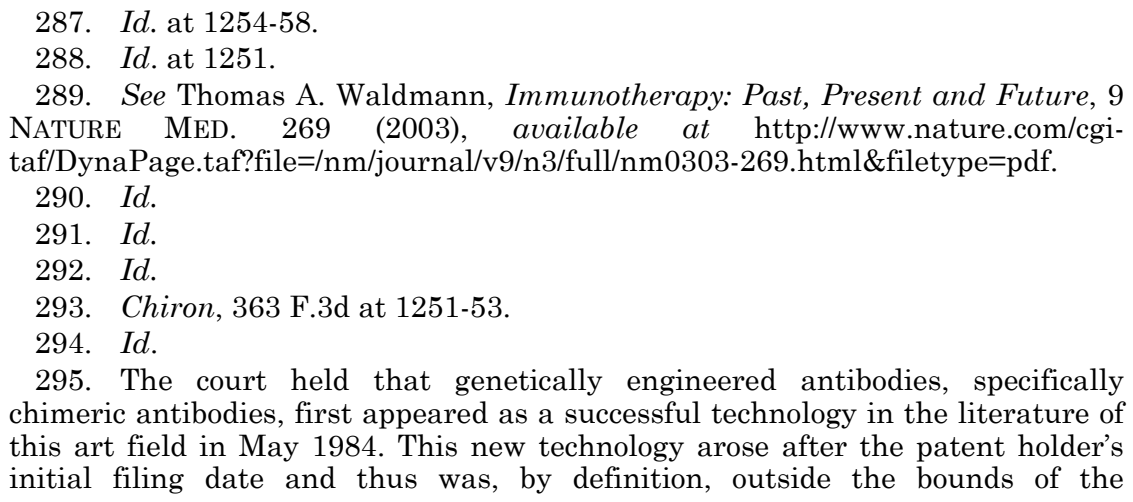
chimeric antibodies, first appeared as a successful technology in the literature of this art field in May 1984. This new technology arose after the patent holder's initial filing date and thus was, by definition, outside the bounds of the 
Post-grant review should be structured to allow potential infringers or other interested parties to present negative claim constructions to the Patent Office for review because the breadth of claim construction is inherently tied to claim validity. As the Chiron case illustrates, broad claim construction is a two-edged sword. While an expansive reading of the patent's claims may help the patent owner assert her rights more broadly, it may also jeopardize the validity of the patent. Broadly interpreted patent claims expand the universe of potentially invalidating prior art, and make it more difficult to meet the statutory requirements of written description and enablement. 296

The Patent Office could respond to a request for a negative claim construction in one of three ways: (1) determine that the claim in question does not cover the defined product, process, or method; (2) determine that the claim in question does cover the defined product process or method, but that in light of that construction the patent should not have been issued; (3) neither 1 nor 2 (which carries the implication that the claim in question covers the defined product, process, or method). Where the Patent Office determines that the claim in question does not cover the defined product, process, or method (option 1), that negative construction would have to be taken into account in any subsequent litigation. Where the Patent Office determines that the claim in question does cover the defined product, process, or method but that in light of that construction the patent should not have been issued (option 2), the patent would be presumptively invalid with respect to that claim. Where the Patent Office makes neither of those determinations (option 3), the patent would be entitled to a strong presumption of validity with respect to an infringer who fell within the specifications of the negative construction.

How does this relate to our proposed threshold of a substantial new question of patentability? Essentially, we

enablement requirement. The Court further held the patent holder's later applications in 1985 and 1986 also failed to meet the enablement requirement because even though the technology to genetically engineer chimeric antibodies existed at that point, in order to claim rights with respect to a nascent technology the patent would have to have provided a "specific and useful teaching." Id. at 1257.

296. 35 USC $\S 112$ (2000). The specification shall contain a written description of the invention, and of the manner and process of making and using it, in such full, clear, concise, and exact terms as to enable any person skilled in the art to which it pertains, or with which it is most nearly connected, to make and use the same, and shall set forth the best mode contemplated by the inventor of carrying out her invention. $I d$. 
envisage that the Patent Office would review applications for a negative claim construction to determine whether they raised a significant or serious question. Although this is not the same as substantial new question of patentability, it could be employed in a similar filtering fashion. The Patent Office should be given a broad discretion to decide whether to consider applications for negative claim constructions; it should also be allowed to develop an appropriate filtering standard under its rule making authority. ${ }^{297}$

\section{Disputed Features of Post-Grant Review}

The procedural details of post-grant review are of critical importance because post-grant review only makes sense if it presents a viable low cost alternative to litigation. Accordingly, commentary typically focuses on the attractiveness of post-grant review to potential challengers. ${ }^{298}$ However, the question of differential cost is just as significant as cost in general. As we have argued at length in this article, an important criterion should be whether any proposed element of post-grant review imposes higher costs on bad patents than it does on good patents. This leads us to make the following recommendations with respect to other disputed features of post-grant review.

\section{Issues of Format, Scope and Discovery}

The fundamental design constraint for post-grant review is cost. If post-grant review is going to work as a genuine alternative to litigation, it must be significantly more affordable than patent litigation. Controlling the legal costs of post-grant review requires eliminating the two greatest expenses of litigation: discovery and oral argument. In contrast to the proposals for limited discovery in the House and Senate Bills ${ }^{299}$ and the recommendations of the NAS and the FTC, ${ }^{300}$ we believe that so long as the scope of reviewable issues is kept narrow, discovery will be unnecessary.

297. 35 U.S.C. $\S 2(b)(2)(2000)$ (powers and duties of the United States Patent \& Trademark Office).

298. Kesan \& Gallo, supra note 22, at 101 (describing how many "bad" patents are never revoked or even challenged in court).

299. Patent Act of 2005, H.R. 2795, 109th Cong. § 9 (draft amendment to H.R. 2795 recommended discovery for depositions of persons submitting affidavits or declarations as well as any additional discovery that is "required in the interest of justice").

300. See NAS REPORT, supra note 24, at 96; FTC REPORT, supra note 4, at 11. 
This, in turn, requires that the scope of issues under review in post-grant review be limited so that the exclusion of discovery and oral argument does not lead to injustice. Consistent with the House Bill and the Senate Bill, we believe the scope of post-grant review should be limited to issues relating to patentability. This ensures that the Patent Office can review the patent without any inquiry into the inventor's state of mind or personal knowledge at the time of the application. The practical effect of this recommendation is that post-grant review would extend to novelty, obviousness, and enablement, but would not include issues such as statutory bars, best mode or inequitable conduct. Given these limitations, both discovery and oral arguments should not be necessary for the parties to make effective arguments concerning patentability.

\section{Window of Opportunity}

If post-grant review is going to provide a real alternative to litigation, it must be available to potential infringers at any point in time after the patent has issued. The NAS, the FTC, and the current House Bill all recommend a limited time period during which post-grant review may be utilized, varying from nine months to a year. ${ }^{301}$ The NAS further proposes a trigger allowing post-grant review whenever the patent holder alleges infringement by lawsuit or notice of intent to file suit. 302

In contrast, we believe that post-grant review must be available for the life of the patent. Critics suggest that the opposition period be limited for a variety of reasons: a limited period reduces the misuse of post-grant review proceedings by challengers who wish to delay or injure the patent holder; 303 property law favors a settled title because this allows value expectations to settle, thereby engendering commercial stability and fostering the market for patent licensing; ${ }^{304}$ and efficiency results from reducing uncertainty over patent validity. 305 While these are real concerns, we see more immediate and definable negative effects that result from a limited time period for post-

301. See NAS REPORT, supra note 24, at 115 (one year window plus a trigger); FTC REPORT, supra note 4, at 234-235, n.168 (citing the PTO's one year recommendation and recommending a fixed period for post-grant review availability); Patent Reform Act of 2005, H.R. 2795, 109th Cong. § 9 (2005).

302. See NAS REPORT, supra note 24, at 115.

303. Farrell \& Merges, supra note 22, at 968.

304. Id. at n.74 (quoting Steven G. Kunin \& Anton W. Fetting, The Metamorphosis of Inter Partes Reexamination, 19 BERKELEY TECH. L.J. 971 (2004).

305. Kesan \& Gallo, supra note 22, at 91. 
grant review.

First, a limited time period for post-grant review creates a burden on firms to actively and closely monitor every Patent Office proceeding for subject matter which relates to their current or future products. Interested third parties who fail to monitor Patent Office proceedings would reside in an information void. They would be precluded in many instances from availing themselves of the low cost post-grant review alternative to litigation. This monitoring is an across-the-board increase in costs.

Second, if bad patent holders know that competitors do not closely monitor Patent Office proceedings, bad patent holders have an incentive to wait until the close of the opposition period before asserting their patents. Similarly, holders of good patents who are nonetheless uncertain of their patent's strength have an incentive to wait until the limited opposition period closes before asserting their rights. If no limited opposition period existed, it would make no difference when holders of good patents asserted their rights, as they could assert their rights whenever it became strategically optimal for them to do so.

Third, it is relatively uncommon for patents to be litigated within the first nine months after issuance. ${ }^{306}$ According to John Allison et al., patent litigation, on average, reaches a peak during the third year following issuance and continues at a significant pace through at least the fifteenth year following issuance. ${ }^{307}$

\section{Estoppel}

It is widely agreed that the current inter-partes reexamination system has been underutilized because challengers who fail to persuade the Patent Office in reexamination are estopped from raising the same arguments in subsequent litigation. 308 The House Bill repeats this short-coming with respect to post-grant review. Specifically, the House Bill bars a challenger from raising "any issue of fact or law actually decided and necessary to the determination" of an opposition proceeding once a final determination of that opposition has been made. ${ }^{309}$ The House Bill provides an exception for a challenger

306. Allison, supra note 76, at app. Fig. 1.

307. Id.

308. See supra notes 257-259 and accompanying text.

309. Patents Depend on Quality Act of 2006, H.R. 5096, 109th Cong. § 2 (2006). 
who demonstrates that there is additional material factual evidence that could not reasonably have been discovered or presented in the opposition proceeding. ${ }^{310}$

The Senate Bill takes a slightly different approach. This Bill proposes a limited form of estoppel for challenges initiated within a year of the issuance of the patent and a broader form of estoppel for any challenge initiated thereafter. ${ }^{311}$ Under the limited estoppel approach, a challenger would only be estopped from raising an issue of fact or law that it did in fact raise in opposition. In contrast, under the broader form of estoppel potential infringers wishing to avail themselves of post-grant opposition would be barred from subsequently raising any grounds they raised or could have raised in the opposition proceeding. ${ }^{312}$

We disagree with both the House and the Senate Bills in this respect because post-grant review can only be effective if potential infringers are willing to use it. Accordingly, we propose entirely removing estoppel from post-grant review. The argument against removing estoppel is that it serves to prevent repetitive or harassing proceedings and litigation. There are two problems with this reasoning. First, it assumes that repetitive or harassing litigation is a more significant problem than an under-utilized system of post-grant review. Second, there are better ways of protecting the legitimate interests of patent holders and preventing the inappropriate use of post-grant review. For example, as we have already proposed, post-grant review could be divided into two phases, so that patent challengers have to essentially pre-qualify for the right to challenge the patent.

\section{Amendment of Claims during Post-Grant Review}

We propose that amendments be allowed during post-grant review, but that they nonetheless be subjected to the same adversarial proceedings as all other patentability considerations during post-grant review. In some respects, this differs from other recommendations. The NAS report is silent on this matter. ${ }^{313}$ The FTC recommends allowing amendments, but does not address the issue of whether they may be argued against by the challenger. ${ }^{314}$ It would seem imprudent not to allow the

310. Id.

311. Patent Reform Act of 2005, S. 3818, 109th Cong. $§ 9$ (2006).

312. Id.

313. See NAS REPORT, supra note 24.

314. See FTC REPORT, supra note 4, at 16, 193-96. 
expertise and information forwarding capabilities of the challenger to be heard. Though the challenger may be motivated by different concerns than the Patent Office, the Patent Office would still be the ultimate arbiter of patentability issues and should be able to separate rhetoric from truly relevant prior art and argument. The undesirable alternative is to allow uncontested amendments, which could eventually be subjected to another round of post-grant review challenges based on new submissions by the current challenger. This is an inefficient use of resources and the probability of later challenges should be eliminated through the use of a more timely challenge during the amendment process.

\section{E. THE IMPLICATIONS OF DIFFERENTIAL IMPACT FOR POST-GRANT REVIEW}

The differential impact criteria we have established in this article suggest the implementation of a very different kind of post-grant review system from those that are currently on the table. The first point of departure is the variable presumption of validity. The main advantage of applying a variable presumption of validity is that it differentiates based on patent characteristics that are tied to validity in a probabilistic sense. Patents that are issued and never challenged have probably only been scrutinized for between 18 and 41.5 hours, 315 whereas a patent that has been subject to post-grant review will have been subjected to hundreds of hours of intensive examination. Thus, a patent which is upheld after post-grant review seems much more likely to be valid than one which has not. Another advantage of the variable presumption of validity is that it facilitates a streamlined postgrant review system that does not overlap with judicial proceedings by applying a presumption of invalidity to patents that are successfully challenged in post-grant review. Our proposal is that post-grant review should not be the subject of any appeal. Rather, a patent holder who believes that the Patent Office was in error should simply attempt to enforce her rights in court. If she is successful, the Patent Office's post-grant review determination is effectively overruled, if not, the ruling stands. This streamlined system will keep the cost of post-grant review affordable and will also make it clear that post-grant review is not simply an alternative forum for litigation.

315. See supra note 62 . 
The second point of departure between the system of postgrant review we envisage and the current raft of legislative proposals is that we believe that post-grant review should be comprised of two distinct stages. Under our proposed multi-stage post-grant review, challengers would have to effectively earn the right to challenge a patent by convincing the Patent Office that they were able to demonstrate some substantial new question of patentability that had not yet been considered at the time the patent was initially examined. MPGR may be more efficient than a single stage process because it allows potential infringers to resolve one of the major uncertainties of patent litigation very early in the process. It is often the case that a potential infringer will form the opinion that a particular piece of prior art is fatal to the validity of the patent, but to test that opinion currently requires commitment to substantial litigation costs. This filtering device will narrow down those cases eligible for post-grant review to those instances where there is clearly a significant question to be addressed. While this may allow a number of invalid patents to escape post-grant review, it will also protect the majority of good patents from unmeritorious post-grant review proceedings. Multistage post-grant review is essential to ensuring that post-grant review has more impact on bad patents than on good ones by balancing the need for low cost challenge with the need to protect patent holders from undue harassment.

Our third point of departure with the current post-grant review proposals relates to claim construction. Currently the only way a potential infringer can obtain any certainty with respect to ambiguous patent claims is via federal court litigation. However, this is only an option to persons who have a reasonable apprehension of being sued for infringement by the patent holder. This seems overly restrictive because it does not provide any means whereby a person can test the meaning of a patent claim without investing in activity that is potentially infringing. Our proposal is that potential infringers should be able to negate certain claim constructions through post-grant review.

\section{CONCLUSION}

Congressional efforts to address the crisis of confidence in the United States patent system have failed up to the present day. If Congress is to have any hope of passing much needed legislative reform to the Patent Act, the supporters of patent reform will have to unite behind a streamlined set of proposals that directly address the most pressing and unambiguous defects of the current patent system. To that end, we have proposed applying a 
test of differential impact to enable Congress to prioritize those reforms which will discourage the acquisition and assertion of bad patents without unduly prejudicing the interests of the holders of good patents. The differential impact approach elucidated in this article has three distinct advantages over other, proffered efforts to rewrite the patent system from the ground up. First, the differential impact approach provides a mechanism by which to evaluate competing claims for legislative resources. Second, the differential impact approach is an appropriate response to the empirical uncertainty surrounding optimal patent scope. Third, differential impact is consistent with the need to take the legitimate expectations of current stakeholders into account.

The economic models developed in this article suggest that individuals and businesses accused of patent infringement often have weak incentives to challenge bad patents, even when they are fairly sure those patents are invalid. Additionally, these economic models demonstrate that patent holders have strong incentives to demand royalties which are not in fact supported by the patents they hold. These demands may be unsupported either because the patent is invalid, or because it is much narrower in scope than the patent holder represents. The AF-model indicates that where targeting costs are low and the prospect of retaliation is small, a rational patent holder will broadly assert her patent even where the probability that any individual target will accept a license is low. The AF-model is particularly useful in determining which proposed reforms are likely to have a differential impact on bad patents because it indicates that exposing patent holders to retaliation when they assert their patents has the potential to create a differential cost between good patent holders and bad patent holders.

In Part III of this article we have reviewed a wide range of reform proposals relating to patent examination, substantive patent doctrine, the structure and procedures of patent litigation. Of all the reforms surveyed, the one that appears to have the best potential for differential impact is post-grant review.

The importance of post-grant review is highlighted by the economic models developed in this article. First, the CF-model indicates that the high cost of federal court litigation shields bad patents from scrutiny in many cases. Post-grant review will address this by providing a low cost method of challenging patents. Second, the AF-model indicates that it would be more costly to assert bad patents if the expected cost of retaliation for asserting a bad patent was significantly higher than the expected 
cost of retaliation for asserting a good patent. Currently, both good and bad patents are placed at considerable risk in federal court litigation. 316 However, in post-grant review, only bad patents have a significant probability of being invalidated. Consequently, the AF-model indicates that introducing a system of post-grant review would discourage the assertion of bad patents without discouraging the assertion of good patents. Third, both the CF-model and the AF-model indicate that uncertainty and information asymmetries relating to patent quality are detrimental to good patents and advantageous to bad patents. Under a system of post-grant review, potential infringers will be able to resolve key questions relating to patent validity more quickly and more cheaply than in federal court litigation. As a result, post-grant review will also have a differential impact on bad patents by reducing uncertainty and information asymmetries relating to patent quality.

In order to further demonstrate the utility of our differential impact approach, we have applied the standard to sketch an outline of how post-grant review should be implemented. Interestingly, looking at post-grant review through the lens of differential impact leads us to propose a very different kind of system to that currently embodied in the House Bill, the Senate Bill or those proposed by the FTC, the NAS and various other commentators. ${ }^{317}$

Adopting the differential impact standard elaborated in this article will enable Congress to evaluate and prioritize competing patent reform proposals. As such, the differential impact test provides a way out of the legislative quagmire that seems to have engulfed the patent reform movement.

316. This is not to suggest the risk is the same regardless of the underlying validity of the patent.

317. The differences between our MPGR proposal and other versions of postgrant review are summarized at the beginning of this article. See supra Part IV. 